UNIVERSIDADE DE SÃO PAULO

FACULDADE DE FILOSOFIA, LETRAS E CIÊNCIAS HUMANAS DEPARTAMENTO DE CIÊNCIA POLÍTICA PROGRAMA DE PÓS-GRADUAÇÃO EM CIÊNCIA POLÍTICA

\title{
LEANDRO DE PÁDUA RODRIGUES
}

A PRODUÇÃO HABITACIONAL DO PROGRAMA MINHA CASA MINHA VIDA NA REGIÃO METROPOLITANA DE SÃO PAULO

\author{
v.1 \\ VERSÃO REVISADA \\ SÃO PAULO \\ 2015
}




\section{UNIVERSIDADE DE SÃO PAULO \\ FACULDADE DE FILOSOFIA, LETRAS E CIÊNCIAS HUMANAS DEPARTAMENTO DE CIÊNCIA POLÍTICA PROGRAMA DE PÓS-GRADUAÇÃO EM CIÊNCIA POLÍTICA}

\section{A produção habitacional do Programa Minha Casa Minha Vida na região metropolitana de São Paulo}

LEANDRO DE PÁDUA RODRIGUES

Dissertação apresentada ao Departamento de Ciência Política da Universidade de São Paulo para a obtenção do título de Mestre em Ciência Política.

Área de concentração: Políticas Públicas

Orientador: Professor Livre-docente Eduardo Marques

v.1

VERSÃO REVISADA

São Paulo

2015 
Nome: Leandro de Pádua Rodrigues

Título: A produção habitacional do Programa Minha Casa Minha Vida na Região metropolitana de São Paulo

Dissertação apresentada ao Departamento de Ciência

Política da Universidade de São Paulo para a obtenção do título de Mestre em Ciência Política.

Aprovado em:

Banca examinadora

Professor(a) Doutor(a):

Instituição:

Julgamento:

Professor(a) Doutor(a):

Instituição:

Julgamento:

Professor(a) Doutor(a):

Instituição:

Julgamento: 
Para Adriana e Martin por todo o apoio e pelo gosto musical, mas também pelas ausências que me ensinaram o que buscar na vida - "porque a ausência, essa ausência assimilada, / ninguém a rouba mais de mim" (Carlos Drummond). 


\section{Agradecimentos}

A primeira pessoa a quem devo agradecer é meu orientador Professor Doutor Eduardo Marques, ou apenas Edu para os alunos da graduação e da pós. Seus conselhos esuas orientações foram essenciais, especialmente na reta final desta pesquisa. Por isso, o meu sincero obrigado. Aos meus amigos que entraram junto comigo no mestrado, em 2011, Telma, Carolina, Patrick e Paulo, que, de um jeito ou de outro, contribuíram também: seja por uma conversa simples do cotidiano, ou pelas discussões sobre os temas da Ciência Política, ou de Políticas Públicas.

À Professora Doutora Luciana Royer e à Professora Doutora Gabriela Lotta, que fizeram parte da banca da qualificação e fizeram comentários e críticas construtivas de suma importância para o aprimoramento desse trabalho.. Quero agradecer também ao Nédio Henrique Filho, quem me atendeu diversas vezes na Caixa Econômica Federal para tirar minhas dúvidas sobre o programa. Nesse mesmo sentido, quero agradecer à Camila Braga, da GIDUR-Caixa, Ronaldo Cury, da Construtora Cury, e André Del Nero da Construtora Enccamp. Essas pessoas esclareceram muitos pontos sobre o Minha Casa Minha Vida.

O Departamento de Ciência Política e o Centro de Estudos da Metrópole (CEM) foram instituições fundamentais também ao desempenho desta pesquisa, pois me ofereceram todo o suporte necessário. À Caixa e ao Ministério das Cidades, por me disponibilizarem todos os dados necessários para esta pesquisa, bem como pelas cartografias e bases de dados utilizadas.

Por fim, quero agradecer aos meus amigos próximos, que me ajudaram de diversas formas, e, em diversas etapas desta pesquisa, e também, agradecer à minha família: meu pai, minha mãe, minha irmã e irmão. Obrigado! 
RESUMO

RODRIGUES, L. P. A produção habitacional do Programa Minha Casa Minha Vida na Região Metropolitana de São Paulo. 2013125 f. Dissertação de Mestrado - Faculdade de Filosofia, Letras e Ciências Humanas da Universidade de São Paulo, São Paulo, 2013.

Esta dissertação realiza uma análise empírica do Programa Minha Casa Minha Vida na Região Metropolitana de São Paulo, utilizando os dados de produção habitacional do programa, o Censo 2010, as bases cartográficas do CEM, entre outros dados. Além disso, as diversas leis que regulam o programa fazem parte do material empírico analisado. Com essas informações, são discutidos três argumentos que a literatura sobre o Minha Casa MinhaVida propõe: a adequação do programa ao perfil do déficit habitacional, o caráter de mercado do programa em detrimento de uma política social, e a relação do programa com a segregação urbana. O objetivo deste debate não é discordar dos argumentos propostos pela literatura, mas sim, adicionar informações que tornem as críticas ao programa mais nuançadas, destacando que a produção habitacional do programa não possui tantos aspectos negativos como foi apontado pela crítica, assim que o Minha Casa Minha Vida foi lançado em 2009.

Palavras chaves: produção habitacional, Programa Minha Casa Minha Vida, política habitacional, segregação, déficit habitacional, Região Metropolitana de São Paulo. 


\begin{abstract}
RODRIGUES, L. P. A produção habitacional do Programa Minha Casa Minha Vida na Região Metropolitana de São Paulo. 2013125 f. Dissertação de Mestrado - Faculdade de Filosofia, Letras e Ciências Humanas da Universidade de São Paulo, São Paulo, 2013.

This dissertation conducts an empirical analysis of My house My life (Program Minha Casa Minha Vida) in the Metropolitan Region of São Paulo, using data from the program housing production, Census 2010, and CEM cartographic databases, among other data. In addition, various laws governing the program are part of the empirical material analyzed. With this information, we discuss three arguments that the literature on My life My house proposes: the appropriateness of the program to the housing deficit, the market feature of the program to the detriment of social policy, and the relationship of the program with urban segregation. The aim of this discussion is not to disagree with arguments proposed in the literature, but add information to throw lights to the critics making them more nuanced program, noting that the program housing production lacks many negative aspects that were pointed out by the critics when it was released in 2009 .
\end{abstract}

Key words: housing production, My house My life, housing policy, segregation, housing deficit, the Metropolitan Region of São Paulo. 


\section{LISTA DE MAPAS}

Mapa 1 Localização dos empreendimentos da faixa 1 do MCMV, RMSP (Fonte: Dados da Caixa Econômica Federal trabalhados em cartografia CEM) 111

Mapa 2 Localização dos empreendimentos da faixa 2 do MCMV, RMSP (Fonte: Dados da Caixa Econômica Federal trabalhados em cartografia CEM) 111

Mapa 3 Localização dos empreendimentos da faixa 3 do MCMV, RMSP (Fonte: Dados da Caixa Econômica Federal trabalhados em cartografia CEM) 112 


\section{LISTA DE TABELAS}

Tabela 1 Promoção de unidades habitacionais por entidades públicas (Brasil 1930-1964) (Fonte:BONDUKI, 2014, p. 51)

Tabela 2 Quantidade de recurso financeiro que seria aportada à FCP (Fonte: ANDRADE; \& AZEVEDO, 1982, p. 24) 30

Tabela 3 Produção habitacional do período de 1964 a 1986 (Fonte: BONDUKI, 2014, p. 65).

Tabela 4 Participação percentual dos financiamentos habitacionais concedidos pelo SFH através de contratos - Brasil - 1964/1975 (Fonte: MARICATO, 1987, p. 47).....

Tabela 5 Número de contratos e valor financiado com recursos do FGTS por programas Brasil (1995-2003) (Fontes: BONDUKI, 2014, p.103). 36

Tabela 6 Destino do recurso financeiro da primeira fase do PMCMV (Fonte: MCidades/SNH/DHAB. In: BRASIL, 2010a, p. 52)

Tabela 7 Resumo das informações principais sobre as faixas de atendimento (Fonte: legislação sobre o PMCMV). 46

Tabela 8 Comercialização (em UH) de moradia pelo PMCMV - PF, fases 1 e 2 do programa (Fontes: dados da CEF trabalhados pelo CEM) - até junho de 2014 48

Tabela 9 Unidades contratadas pelo PMCMV - PJ, fases 1 e 2 do programa (Fontes: dados da CEF trabalhados pelo CEM) - até junho de 2014

Tabela 10 Componentes centrais do conceito do déficit habitacional (Fonte: Estudo do déficit de 2008, FJP).

Tabela 11 Principais diferenças nas metodologias dos estudos do déficit (Fonte: FUNDAÇÃO JOÃO PINHEIRO, 2013, p. 77)

Tabela 12 Distribuição das UH por estado, e faixas, organizada pela faixa 1 do maior para menor (Fonte: dados da CEF trabalhados a partir do CEM) 
Tabela 13 Distribuição do déficit habitacional urbano por estado e por faixa salarial (Fonte: Estudo do déficit habitacional 2010, Fundação João Pinheiro) - em \%

Tabela 14 Municípios que doaram terrenos ao PMCMV - FAIXA 1 (Fonte: dados da CEF trabalhados pelo CEM).

Tabela 15 Resumo das diferenças entre faixa 1 e faixas 2 e 3 (Fonte: Legislação do PMCMV disponível na bibliografia). 85

Tabela 16 Resumo das diferenças entre imóvel na planta e apoio à produção (Fonte: Legislação do PMCMV disponível na bibliografia)

Tabela 17 Produção dos empreendimentos por tipo de Pessoa Jurídica e Faixa - em \% (Fonte: dados da CEF trabalhados pelo CEM). 89

Tabela 18 Produção dos empreendimentos pelo nome do ramo empresarial do registro do CNPJ e Faixa - em \% (Fonte: dados da CEF trabalhados pelo CEM) 90

Tabela 19 Produção dos empreendimentos pelo nome da empresa e Faixa - em \% (Fonte: dados da CEF trabalhados pelo CEM) 91

Tabela $20 \mathrm{DH}$ urbano da RMSP por faixa, produção de unidades pelo PMCMV e proporção do DH atendido (Fontes: Cálculo do CEM a partir de dados da CEF e da FJP) 104

Tabela 21 Municípios que não atenderam o DH na faixa 1 (Fontes: Cálculo do CEM a partir de dados da CEF e da FJP) 104

Tabela 22 Municípios que atenderam entre 4\% a 10\% do DH na faixa 1 (Fontes: Cálculo do CEM a partir de dados da CEF e da FJP) 105

Tabela 23 Municípios que atenderam entre $12 \%$ a 20\% do DH na faixa 1 (Fontes: Cálculo do CEM a partir de dados da CEF e da FJP) 106

Tabela 24 Municípios que atenderam entre 28\% a 38\% do DH na faixa 1(Fontes: Cálculo do CEM a partir de dados da CEF e da FJP) 106 
Tabela 25 Municípios que atenderam entre mais de 60\% do DH na faixa 1(Fontes: Cálculo do CEM a partir de dados da CEF e da FJP)

Tabela 26 Distribuição das UH por município da RMSP e pelo produto da CEF (Fonte: Dados da Caixa Econômica Federal trabalhados pelo CEM, e CENSO 2010) *Urbanização, **Apoio à produção ***Imóvel na Planta ****População Censo 2010 109

Tabela 27 Estatísticas descritivas das distâncias dos empreendimentos do PMCMV (por faixa) às centralidades e aos equipamentos públicos. (Fonte: Dados da CEF, trabalhados sob cartografia do CEM)

Tabela 28 Estatísticas descritivas das distâncias de COHAB e CDHU às centralidades e aos equipamentos públicos. (Fonte: Dados da CEF, trabalhados sob cartografia do CEM) 118

Tabela 29 Distâncias a centralidades por faixas MCMV, Cohab e Cdhu (km) (Fonte: Dados da CEF, trabalhados sobre cartografias CEM)

Tabela 30 Distribuição dos centros mais próximos a empreendimentos MCMV, por faixas (\%) (Fonte: Dados da Caixa Econômica Federal, trabalhados sobre cartografias CEM) 122

Tabela 31 Distâncias medianas a conjuntos e equipamentos $(\mathrm{Km})$, por faixa (Fonte: Dados da Caixa Econômica Federal, trabalhados sobre cartografias CEM) 123

Tabela 32 Distâncias medianas a conjuntos e equipamentos $(\mathrm{Km})$ exclusivos da cidade de São Paulo (Fonte: Dados da Caixa Econômica Federal, trabalhados sobre cartografias CEM)

Tabela 33 Características sociais médias dos entornos (1000 metros) do MCMV, COHAB, CDHU e RMSP, 2010 (Fonte: Dados da Caixa Econômica Federal, trabalhados sobre cartografias CEM) 127

Tabela 34 Características sociais médias dos entornos (1000 metros) dos empreendimentos entregues e dos não entregues da faixa 1(Fonte: Dados da CEF, CENSO 2010, trabalhados sobre cartografias CEM) 135 
Tabela 35 Média das distâncias dos empreendimentos aos itens selecionados (Fontes: dados da CEF trabalhados sob cartografia do CEM)

Tabela 36 Distribuição das unidades concluídas da faixa 1 por município (Fontes: dados da CEF trabalhados sob cartografia do CEM).

Tabela 37 Distribuição das unidades concluídas da faixa 1 por centralidade mais próxima (Fontes: dados da CEF trabalhados sob cartografia do CEM) 137 


\section{LISTA DE GRÁFICOS}

Gráfico 1Taxa de Urbanização do Brasil (Fonte: Site do IBGE)

Gráfico 2 População por situação de domicílio (população presente e residente) (Fonte: Site do IBGE)

Gráfico 3 Evolução histórica da média anual da inflação no setor da habitação, de acordo com o Índice nacional de preço ao consumidor, apenas a parte da Habitação (Fonte: IBGE) 34

Gráfico 4 Evolução histórica do déficit habitacional total no Brasil - em milhões (Fontes: estudos do Déficit habitacional para os anos de 2000, 2008, 2009, 2010, 2011 e 2012) 55

Gráfico 5 Evolução das unidades contratas pelo PMCMV por ano e por faixas (Fontes: dados da CEF trabalhados pelo CEM) 57

Gráfico 6 Evolução da redução do déficit habitacional urbano (num cenário hipotético) em termos absolutos, por ano (Fonte: dados da CEF trabalhos pelo CEM)

Gráfico 7 Correlação entre o déficit habitacional urbano e a produção habitacional por faixa e por ano (Fonte: dados da CEF trabalhados pelo CEM).

Gráfico 8 Proporção do déficit habitacional urbano do norte atendido pelas unidades contratadas até junho de 2014 (Fontes: FJP e CEF, dados trabalhos no CEM). 64

Gráfico 9 Proporção do déficit habitacional urbano do nordeste atendido pelas unidades contratadas até junho de 2014 (Fontes: FJP e CEF).

Gráfico 10 Proporção do déficit habitacional urbano do centro-oeste atendido pelas unidades contratadas até junho de 2014 (Fontes: FJP e CEF)

Gráfico 11 Proporção do déficit habitacional urbano do sudeste atendido pelas unidades contratadas até junho de 2014 (Fontes: FJP e CEF) 65

Gráfico 12 Proporção do déficit habitacional urbano do sul atendido pelas unidades contratadas até junho de 2014 (Fontes: FJP e CEF) 66 
Gráfico 13 Em \% - Lançamentos imobiliários e empreendimento contratados pelo PMCMV (Fonte: banco de lançamentos imobiliários organizado pelo CEM; dados da CEF trabalhados pelo CEM)

Gráfico 14 : Evolução da média do valor do metro quadrado útil, pelas faixas do PMCMV, e lançamentos imobiliários (Fonte: banco de lançamentos imobiliários organizado pelo CEM; dados da CEF trabalhados pelo CEM) 94

Gráfico 15 Evolução da média do valor do metro quadrado total, pelas faixas do PMCMV, e lançamentos imobiliários (Fonte: banco de lançamentos imobiliários organizado pelo CEM; dados da CEF trabalhados pelo CEM)

Gráfico 16 Evolução do DH em UH na década de 2000 na RMSP (Fonte: Estudos do déficit habitacional da Fundação João Pinheiro) * Esses anos correspondem ao déficit habitacional total, extraídos da reponderação feita no estudo do DH 2008; ** Esses anos correspondem a

Gráfico 17 Evolução das médias das distâncias às centralidades da Faixa 1 (Fonte: Dados da $\mathrm{CEF}$, trabalhados sobre cartografias CEM)

Gráfico 18 Evolução das médias das distâncias às centralidades da Faixa 2 (Fonte: Dados da $\mathrm{CEF}$, trabalhados sobre cartografias CEM) 121

Gráfico 19 Evolução das médias das distâncias às centralidades da Faixa 3 (Fonte: Dados da $\mathrm{CEF}$, trabalhados sobre cartografias CEM)

Gráfico 20 Distribuição dos empreendimentos de cada faixa por tipo de espaço - em \% (Fonte: Dados da Caixa Econômica Federal, trabalhados sobre cartografias CEM) 131

Gráfico 21 Renda dos mutuários finais da faixa 1 comparada com a renda média dos responsáveis pelos domicílios (Fonte: Dados da CEF, CENSO 2010, trabalhados sobre cartografias CEM) 133 


\section{Sumário}

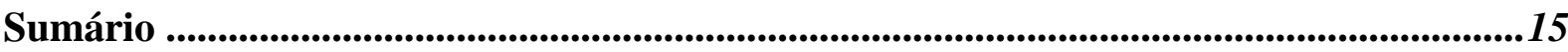

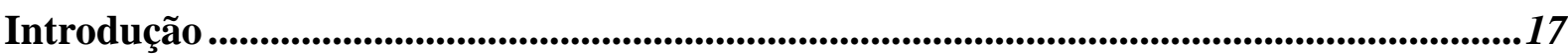

Capítulo 1 A história da produção habitacional federal ..................................................25

1.1 O surgimento dos Institutos de Aposentadorias (IAPs)......................................25

1.2 A criação da Fundação Casa Popular (FCP) .......................................................22

1.3 A criação do Banco Nacional de Habitação no Regime Militar................................... 30

1.4 A extinção do BNH e os dois mandatos de Fernando Henrique (FHC)..................... 34

1.5 A década de 2000 e a criação do Programa Minha Casa, Minha Vida....................... 37

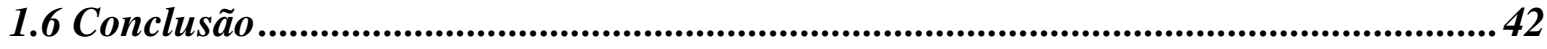

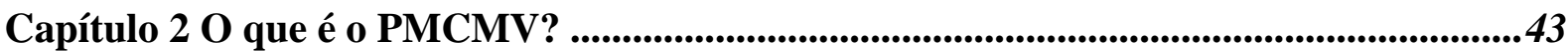

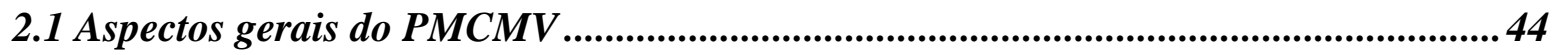

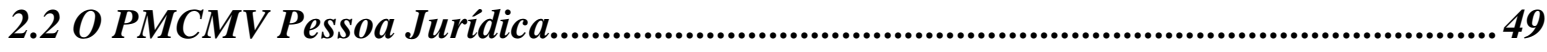

2.30 déficit habitacional no Brasil ........................................................................................51

2.4 A produção habitacional do PMCMV ..........................................................................56

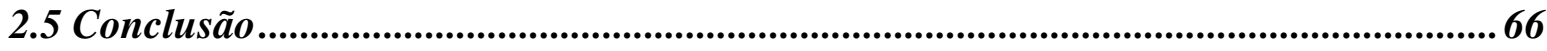

Capítulo 3 Detalhes do processo de produção de empreendimentos pelo PMCMV ........68

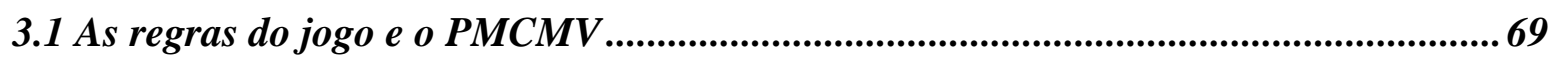

3.2 A aquisição do terreno para o empreendimento .................................................... 71

$3.3 \mathrm{O}$ incorporador e o prestador de serviço ...................................................................... 76

$3.4 O$ processo de aprovação dos projetos de empreendimentos na CEF .......................... 82

3.5 As linhas de financiamentos apoio à produção e imóvel na planta............................85

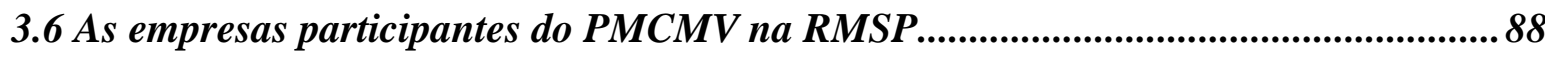

3.7 A produção habitacional do PMCMV e os lançamentos imobiliários na RMSP........ 91

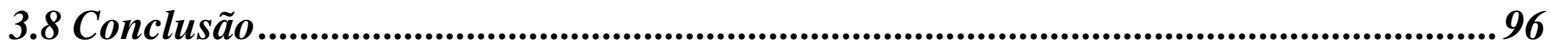

Capítulo 4 A localização dos empreendimentos na RMSP ................................................98

4.1 Considerações conceituais sobre segregação urbana e o PMCMV .............................99 
4.2 Padrões de atendimento do déficit na RMSP.

4.3 Os subprogramas do PMCMV na RMSP e a localização dos empreendimentos...... 108

4.4 Analisando a segregação residencial relacionada ao Minha Casa Minha Vida ......114

4.5 Analisando as unidades habitacionais entregues da faixa 1 ..................................132

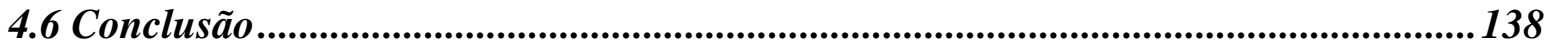

Conclusão

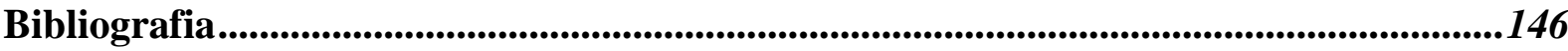

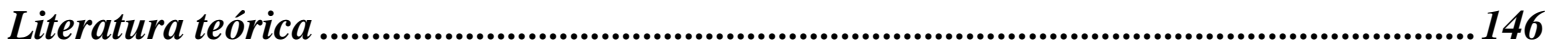

Legislação consultada ................................................................................................................148 


\section{Introdução}

Esta dissertação analisa empiricamente a produção habitacional do Programa Minha Casa, Minha Vida (PMCMV), na Região Metropolitana de São Paulo (RMSP), utilizando dados sobre os empreendimentos desde o lançamento do programa em 2009 até junho de 2014. A principal motivação desta análise é dialogar com alguns argumentos da literatura sobre o programa: o atendimento do déficit habitacional realizado pelo Minha Casa, Minha Vida, o caráter de mercado do programa e a segregação urbana associada ao MCMV. Quando foi lançado, havia um receio de que não seria capaz de atingir as famílias que auferem renda de até 3 salários mínimos, que, historicamente, sempre foram excluídas dos programas habitacionais federais. Cogitava-se a possibilidade da experiência do Banco Nacional de Habitação (BHN) repetir-se, sobretudo, devido a algumas semelhanças entre o PMCMV e o BNH. Como resultado, o Brasil teria novamente uma política habitacional que, no discurso, afirmaria que seriam atendidas as famílias com renda equivalente ou abaixo de 3 salários mínimos, mas que na prática priorizariam aquelas localizadas no limite superior da faixa, ou seja, as que auferem renda entre 3 e 5 salários mínimos.

Outro argumento sobre o programa é a afirmação de que possui um caráter essencialmente mercadológico, ou seja, utiliza um problema social como álibi para promover os interesses das grandes construtoras e incorporadoras. Essa visão está associada ao fato do PMCMV ter desconsiderado na sua proposta grande parte do que vinha sendo discutido no Plano Nacional da Habitação (PlanHab) e na Política Nacional de Habitação (PNH), bem como nas reuniões dos Conselhos das Cidades realizadas anteriormente ao seu lançamento. Essas iniciativas propunham, no geral, que o problema do déficit habitacional não seria resolvido apenas com a construção de unidades novas para a venda. Era preciso olhar cada cidade, cada metrópole, cada estado de acordo com suas especificidades, e propor soluções 
como urbanização de favelas, autoconstrução, urbanização de lotes clandestinos, etc. No processo de decisão sobre quais seriam as melhores soluções, o poder público local deveria participar, bem como os movimentos sociais por moradia.

Nada disso está presente no PMCMV, porque é um programa com o objetivo de incentivar a construção, a requalificação e a aquisição de unidades habitacionais, e foi lançado num contexto de crise econômica mundial como uma iniciativa anticíclica do governo federal para contê-la, gerando emprego e renda. Por isso, o programa precisou assumir um desenho de implementação que possibilitasse a construção de um grande número de unidades habitacionais num curto espaço de tempo. Para tanto, foi utilizado todo o conhecimento acumulado na Caixa Econômica Federal sobre financiamento de habitação ao mercado popular, além das linhas de crédito para as empresas de construção civil. Parte desses conhecimentos originou-se justamente dos espólios do $\mathrm{BNH}$, que foram transferidos justamente para a Caixa Econômica quando o Banco Nacional da Habitação foi extinto.

Coube então à Caixa aprovar ou não os projetos dos empreendimentos, e isso fez parte da literatura sobre o programa afirmar que o poder público local teria pouca participação no processo de produção habitacional. O caráter de mercado do programa, somado com a pouca participação do poder público local e com a urgência de se construir as unidades para enfrentar a crise habitacional, produziriam uma consequência perniciosa: a construção de empreendimentos distantes dos centros e subcentros urbanos, gerando, assim segregação urbana. Decorrente disso também está a baixa qualidade das regiões em termos de infraestrutura urbana e disponibilidade de serviços e equipamentos públicos, pois são terrenos localizados nas franjas do município, com grandes áreas para que mais unidades possam ser construídas, gerando assim, um lucro maior às empresas.

Utilizando dados da produção habitacional do programa, as informações presentes nas Leis que regulam o programa, o Censo de 2010, e algumas cartografias sobre equipamentos e 
serviços públicos, esta dissertação pretende matizar os argumentos apresentados pela literatura sobre o PMCMV. No entanto, antes de expor os argumentos pertinentes, é necessário fazer uma ressalva: a literatura que surgiu com o lançamento do programa em 2009 era composta na sua maioria por, o que se chama na filosofia política, textos de ocasiões, ou seja, textos escritos e publicados no calor dos acontecimentos com o objetivo principal de impactar a direção que o programa assumiria. Por isso, muitos desses textos não eram acompanhados de uma análise empírica mais detalhada, algo impossível no momento, pois o PMCMV tinha produzido poucas unidades habitacionais.

Passados cinco anos de existência do programa, é possível afirmar que muitas dessas críticas obtiveram êxitos, isto é, as regras do programa foram alteradas: o exemplo mais ilustrativo disso é a inexistência de regras e definições de empreendimentos contíguos na Portaria 139 de 2009, alterada em 2011 pela Portaria 465 de 2011. Por outro lado, reconhecendo a dificuldade que alguns municípios enfrentavam em dotar as áreas de equipamentos públicos, como escolas e postos de saúde, a Portaria 168 de 2013 “[estabelece] as condições para contratar a edificação de equipamentos de educação, saúde e outros complementares à habitação, dos empreendimentos contratados com recursos do Fundo de Arrendamento Residencial -FAR” (BRASIL, 2013c).

Apesar desse objetivo positivo alcançado pela literatura crítica ao programa, é possível afirmar que parte dos argumentos críticos não considera que existem dois programas Minha Casa, Minha Vida: o PMCMV destinado exclusivamente para faixa 1 e o PMCMV destinado para as faixas 2 e 3 . Ambos possuem em comum a construção de unidades novas para venda como solução habitacional, mas a produção das moradias ocorre para os dois casos sob regras e atores diferentes. Tais circunstâncias implicam em outras diferenças, como por exemplo, o padrão de atendimento do déficit realizado por cada programa e os tipos de segregação que cada um deles acentua ou não. O estudo detalhado das regras do programa e também de sua 
produção habitacional fornece uma interpretação sobre o MCMV respaldada nas premissas do neoinstitucionalismo da Ciência Política.

Alguns dos argumentos presentes na literatura não são baseados, por exemplo, nas regras do programa, e sim numa exegese da produção habitacional realizada pelo BNH, pois tal como este, no PMCMV cabe a um banco aprovar ou rejeitar os projetos, bem como liberar os recursos financeiros. No entanto, as regras do Minha Casa, Minha Vida são bem diferentes dos programas habitacionais do $\mathrm{BNH}$, o que implica em duas consequências analíticas: primeiramente, é preciso analisar o PMCMV pelo que ele é, e não pelo que deveria ser, ou baseado na experiência do $\mathrm{BNH}$, dada a existência de algumas semelhanças. Para tanto, é preciso considerar as regras gerais e específicas, bem como os atores envolvidos na produção habitacional. Essa é uma contribuição da Ciência Política ao debate sobre o Minha Casa, Minha Vida, realizado na sua maioria por arquitetos e urbanistas.

Quando as regras do PMCMV, os atores e as instituições engajados na produção habitacional são considerados na análise, bem como a distinção entre PMCMV-faixa 1 e PMCMV-faixas 2 e 3, é possível construir uma interpretação diferente sobre o programa federal. Primeiramente, o poder público local, no Minha Casa, Minha Vida- faixa1, não é ausente como parte da literatura indicou, pois para utilizar os recursos financeiros disponibilizados pelo programa, o município deve assinar um termo de adesão ao PMCMV. Este instrumento constrange o governo municipal a criar Zonas de Interesse Social (ZEIS) para a construção dos empreendimentos, ou a transformar em ZEIS os terrenos que já possuem alguma construção de unidade para a faixa 1.

Além disso, o município compromete-se a dotar as áreas com infraestrutura urbana e equipamentos e serviços públicos, e a criar mecanismos para incentivar a produção habitacional de interesse social. Com efeito, alguns autores (LOPES, 2014; DENALDI; KLINK, 2014) argumentam que a participação ativa dos municípios é uma das explicações 
para a produção de empreendimentos dotados de infraestrutura urbana e providos de equipamentos e serviços públicos. Esta dissertação endossa esses argumentos, e adiciona que o papel ativo dos municípios é estabelecido pelo termo de adesão que assinam, bem como as regras que regulamentam o PMCMV.

Os municípios possuem ainda outras funções: realiza o cadastramento das famílias que desejam participar do PMCMV-faixa 1, bem como o sorteio dos beneficiados; cabe ao poder público local fazer o trabalho técnico social, que é o acompanhamento das famílias nos 6 meses que antecedem a mudança à nova moradia, e nos 6 meses seguintes; por fim, o município possui prerrogativas para estabelecer alguns critérios adicionais para selecionar as famílias que serão beneficiadas pelo programa. Portanto, os dois principais argumentos que esta dissertação defende são: é preciso considerar as instituições e atores engajados na produção do programa, bem como as regras do MCMV, pois revelam as atribuições específicas de cada ator e instituição, bem como diferenciam o PMCMV-faixa 1 do PMCMVfaixas 2 e 3. Com esta distinção, é possível realizar uma análise empírica que considera os diferentes atores da produção habitacional da faixa 1, e das faixas 2 e 3, a diferença no atendimento do déficit habitacional, e os diferentes padrões de segregação e qualidade do terreno para os dois programas.

O capítulo 1 retoma os antecedentes da produção habitacional no Brasil, focando os mecanismos de exclusão das famílias com renda de até 3 salários mínimos: a lógica da cidadania regulada (de 1930-1964) e a própria renda dessas famílias (1946-1984). Tanto a Fundação Casa Popular (criada em 1946), como o BNH (criado em 1964), eram políticas habitacionais com caráter de mercado, porque a primeira praticava o retorno financeiro dos empreendimentos, e o segundo, além dessa prática, também aplicava taxas de juros e correção monetária nos financiamentos. Defende-se que nenhuma política habitacional federal reconhecia a fragilidade da capacidade de pagamento das famílias que auferiam renda de até 3 
salários mínimos. O PMCMV inova nesse sentido, ao criar mecanismos explícitos de subsídio, ao praticar taxa de juros zero nos financiamentos, ao conceder isenção nos custos cartoriais, e, ao disponibilizar um Fundo Garantidor da Habitação, que visa proteger as famílias com financiamento, por exemplo, assumindo os valores das parcelas em caso de desemprego. Essas são as principais características do PMCMV-faixa 1, do ponto de vista do mutuário final, e por isso que é sustentado o argumento de que essa parte do programa não possui caráter de mercado, e sim de uma política social que visa incluir a parcela da população excluída historicamente da habitação.

O capítulo 2 analisa a produção habitacional do programa e o atendimento do déficit habitacional a nível federal. Ao contrário do temor que existia quando o programa foi lançado, os dados demonstram que o Minha Casa Minha Vida priorizou os empreendimentos para a faixa 1 de acordo com o déficit habitacional de cada estado, porém, a proporção do déficit na faixa 1 reduzida ainda é pouca. Isto ocorre, pois quando se compara o déficit da faixa 1 com as faixas 2 e 3 nota-se que o primeiro é muito superior ao segundo, e também porque em alguns estados não foi priorizado a construção de unidades para a faixa 1.

O capítulo 3 aprofunda a definição do PMCMV iniciada no capítulo anterior, analisando com mais detalhes as regras e os atores que participaram da produção habitacional na RMSP. Além disso, é descrito o processo de formulação e aprovação dos projetos dos empreendimentos na Caixa. $\mathrm{O}$ argumento defendido nesta etapa é que na faixa 1 a empresa de construção civil participa do processo de produção das habitações enquanto prestadora de serviço, e não como incorporadora, como ocorrem nas faixas 2 e 3. A principal razão disso é que nos empreendimentos da faixa 1, a empresa não compra o terreno que será construído o empreendimento. Embora possa ocorrer uma alteração do valor de uso da terra quando a construção do empreendimento é finalizada, gerando uma valorização daquele terreno, a diferença entre o preço pago pelo terreno e o novo valor gerado não é auferida pela empresa 
de construção civil. De fato, cabe a Caixa comercializar as unidades e o valor do imóvel é fixo, estabelecido pelo Ministério das Cidades. Portanto, na faixa 1, cabe às empresas apenas formular o projeto do empreendimento, apresentá-lo à Caixa, e, caso seja aprovado, executálo.

O capítulo 4 analisa a produção habitacional na RMSP, focando a segregação urbana e a qualidade das regiões com empreendimentos em termos de infraestrutura urbana e equipamentos e serviços públicos. Os dados demonstram que de fato os empreendimentos da faixa 1 são mais periféricos do que os das faixas 2 e 3,e que a segregação ocorre mais em termos de acesso desigual à cidade, sobretudo, devido à dificuldade de mobilidade urbana na metrópole que existe previamente aos empreendimentos. Além disso, a segregação em termos de homogeneidade interna e heterogeneidade externa também ocorre, mas não em grandes proporções, porque na faixa 1, por exemplo, os empreendimentos receberam famílias oriundas de diversas realidades, e com rendas bem variadas. Os empreendimentos da faixa 2 e 3, por sua vez, possuem maior variabilidade interna e estão espalhados em diversas regiões da metrópole. É possível afirmar que em uma escala, as unidades da faixa 1 são mais segregadas do que as das faixas 2 e 3 . Em termos de infraestrutura urbana e disponibilidade de serviços e equipamentos públicos, no geral, o cenário não é tão caótico como se previa, mas a mesma escala de segregação vale para a qualidade das regiões: os empreendimentos da faixa 1 possuem índices menores do que os das faixas 2 e 3.

Para saber se o PMCMV acentuou os padrões de segregação já existentes na metrópole e estabelecidos pela produção habitacional anterior ao programa, é necessário estabelecer um critério de comparação. Defende-se, nesta dissertação, que é plausível comparar as faixas 2 e 3 com a produção anterior ao Minha Casa Minha Vida, porque até o lançamento do programa federal, as políticas habitacionais locais de construção de unidade pouco atendia as famílias com renda de até 3 salários mínimos. Quando se compara as faixas 
2 e 3 com a produção da COHAB e do CDHU, nota-se que a produção do PMCMV é menos segregada, fato que não contribui para acentuar a segregação desses grupos familiares. 


\section{Capítulo 1 A história da produção habitacional federal}

O objetivo deste capítulo é descrever a produção habitacional que foi realizada desde a década de 1930, período em que se iniciou, no Brasil, a produção de habitação social com a participação do Estado (BONDUKI, 2002). Ao longo de todo esse período, a parcela da população de baixa renda permaneceu marginalizada dessa produção habitacional, não tendo acesso à moradia, e essa exclusão histórica é uma das explicações para o alto déficit habitacional que o Brasil possui atualmente. Portanto, o aspecto importante não é analisar se a construção de unidades habitacionais desse extenso período era (in) suficiente, mas sim destacar que existiam mecanismos que excluíam a parcela da população de baixa renda. Apenas no final da década de 2000, ou seja, 70 anos após o surgimento da produção habitacional social, foi criado um programa nacional que incluía mecanismos de subsídio, de isenção dos custos cartoriais, e de seguro do financiamento, capazes justamente de incluir as famílias que auferem renda mensal de até 3 salários mínimos. Esse programa é o objeto de estudo desta pesquisa: o Programa Minha Casa Minha Vida (PMCMV).

\subsection{O surgimento dos Institutos de Aposentadorias (IAPs)}

A política habitacional federal iniciou-se com o surgimento dos Institutos de Aposentadoria (IAPs), os quais foram criados a partir da década de 1930 com o objetivo de reorganizar o setor previdenciário dos trabalhadores urbanos. Os IAPs substituíram ao longo dos anos as diversas Caixas de Aposentadorias e Pensões (CAPs), e inovaram em dois sentidos: "Não eram baseados em empresas, como as CAPs, mas em categorias profissionais amplas [...]. Além disso, a administração dos IAPs não ficava a cargo de empregados e 
patrões, como no caso das CAPs. O governo era $[\ldots]$ parte integrante do sistema" (CARVALHO, 2008, p. 113).

Com esse novo arranjo, o setor da previdência começou a usufruir de maior organização e recurso financeiro, que não era utilizado totalmente na provisão de habitação para os seus associados, pois os institutos ofereciam outros benefícios: a construção de habitação era vista "ora como objetivo importante, ligado à ideia de seguridade social plena, ora como mero instrumento de capitalização dos recursos captados e, portanto, desprovido de fins sociais" (BONDUKI, 2002, p. 101).

Portanto, construir habitação para os membros associados era um dos benefícios que um IAP poderia oferecer, e isto certamente dependia da quantidade de recursos financeiros que um instituto possuía. Eram privilegiadas as categorias profissionais importantes no projeto de desenvolver a industrialização no Brasil, como, por exemplo, o IAP dos industriais. Outro problema desse sistema é que excluía os trabalhadores de outro IAP (os associados dos IAP dos bancários não podiam usufruir dos benefícios do IAP dos industriais), e também toda a força de trabalho que não pertencesse a IAP algum. Desse modo, a construção e o acesso à moradia seguiam a lógica da cidadania regulada: "são cidadãos todos aqueles membros da comunidade que se encontram localizados em qualquer uma das ocupações reconhecidas e definidas em lei” (SANTOS, 1979, p. 75).

O critério de elegibilidade para uma pessoa se tornar cidadão, do ponto de vista do acesso aos direitos sociais, era exercer um trabalho regulamentado por lei, pois assim se associava ao seu respectivo IAP que lhe provia direitos sociais e benefícios previdenciários. Cabia ao Estado regulamentar as atividades profissionais e reconhecer o funcionamento legal dos sindicatos (CARVALHO, 2008) de acordo com os interesses da indústria nacional. Se uma categoria profissional não estivesse reconhecida pelo Estado, não possuiria um sindicato, um IAP, e a pessoa que exercesse tal atividade não poderia usufruir dos direitos sociais e 
trabalhistas. Disso se segue que os conjuntos habitacionais construídos pelos IAPs se destinavam apenas aos seus membros: trabalhadores rurais, trabalhadores autônomos e domésticos estavam excluídos. Era assim que a política habitacional desenvolvida até 1945 excluía, por meio da lógica da cidadania regulada, uma parcela da população brasileira, fato que perdurou até 1964.

\subsection{A criação da Fundação Casa Popular (FCP)}

Em 1946 foi criada a Fundação Casa Popular, "primeiro órgão, de âmbito nacional, voltado exclusivamente para a provisão de residência às populações de pequeno poder aquisitivo" (ANDRADE; AZEVEDO, 1982, p. 19, grifo nosso). Porém, o principal objetivo da FCP nunca foi atingido, pois os resultados da FCP foram pequenos quando comparados com a construção de conjuntos habitacionais realizadas pelos IAPs: durantes seus 18 anos de vida, a FCP construiu 19.156 unidades habitacionais, e os IAPS e 127.195 (BONDUKI, 2014, p.51).

Tabela 1 Promoção de unidades habitacionais por entidades públicas (Brasil 1930-1964) (Fonte:BONDUKI, 2014, p. 51)

\begin{tabular}{|c|c|c|c|c|}
\hline \multirow[t]{2}{*}{ Órgão Promotor } & \multicolumn{2}{|c|}{$\begin{array}{c}\text { Plano A Conjuntos } \\
\text { Residencais }\end{array}$} & \multirow{2}{*}{\begin{tabular}{|c|} 
Plano B \\
Financiamento para \\
construção ou \\
aquisição \\
\end{tabular}} & \multirow[t]{2}{*}{$\begin{array}{c}\text { Total } \\
\text { (Financimento } \\
\text { +Construídas) }\end{array}$} \\
\hline & $\begin{array}{l}\text { Unidades } \\
\text { projetadas }\end{array}$ & $\begin{array}{c}\text { Unidades } \\
\text { Construídas }\end{array}$ & & \\
\hline IAPI - Industriários & 37.505 & 19.779 & 17.219 & 36.998 \\
\hline IAPC - Comerciários & 18.237 & 12.917 & 16.219 & 29.136 \\
\hline IAPB - Bancários & 6.028 & 5.511 & 12.347 & 17.858 \\
\hline IPASE - Servidores públicos & 7.510 & 6.361 & s/i & 6.361 \\
\hline IAPETC - Transportes e Cargas & 6.382 & 3.473 & 2.917 & 6.390 \\
\hline IAPM - Marítimos & 1.345 & 1.345 & 2.451 & 3.796 \\
\hline IAPFESP - Serviços Públicos & 3.151 & 1.603 & 25.053 & 26.656 \\
\hline Total IAPs & 80.158 & 50.989 & 76.206 & 127.195 \\
\hline FCP - Fundação Casa Popular & 20.278 & 19.156 & & 19.156 \\
\hline DHP - Departamento de Habitação Popular & 2.881 & 755 & - & 755 \\
\hline Outros órgãos regionais & 10519 & 5954 & - & $\mathbf{5 9 5 4}$ \\
\hline Áreas residenciais das cidades novas & 24.700 & 22.000 & - & 22.000 \\
\hline Total Geral & 138.536 & 98.854 & 76.206 & 175.060 \\
\hline
\end{tabular}


A quantidade de unidades construídas destinadas à população com pequeno poder aquisitivo era realmente pouca, e isso fica evidente quando se destaca o intenso processo de urbanização que o Brasil começa a passar a partir das décadas de 1950 e 1960. Com o crescimento das cidades que começaram a receber a população rural, cria-se terreno fértil para o surgimento de condições de habitação precárias, uma vez que o Estado e o mercado não eram capazes de produzir uma solução habitacional acessível a essa população.

Gráfico 1Taxa de Urbanização do Brasil (Fonte: Site do IBGE)

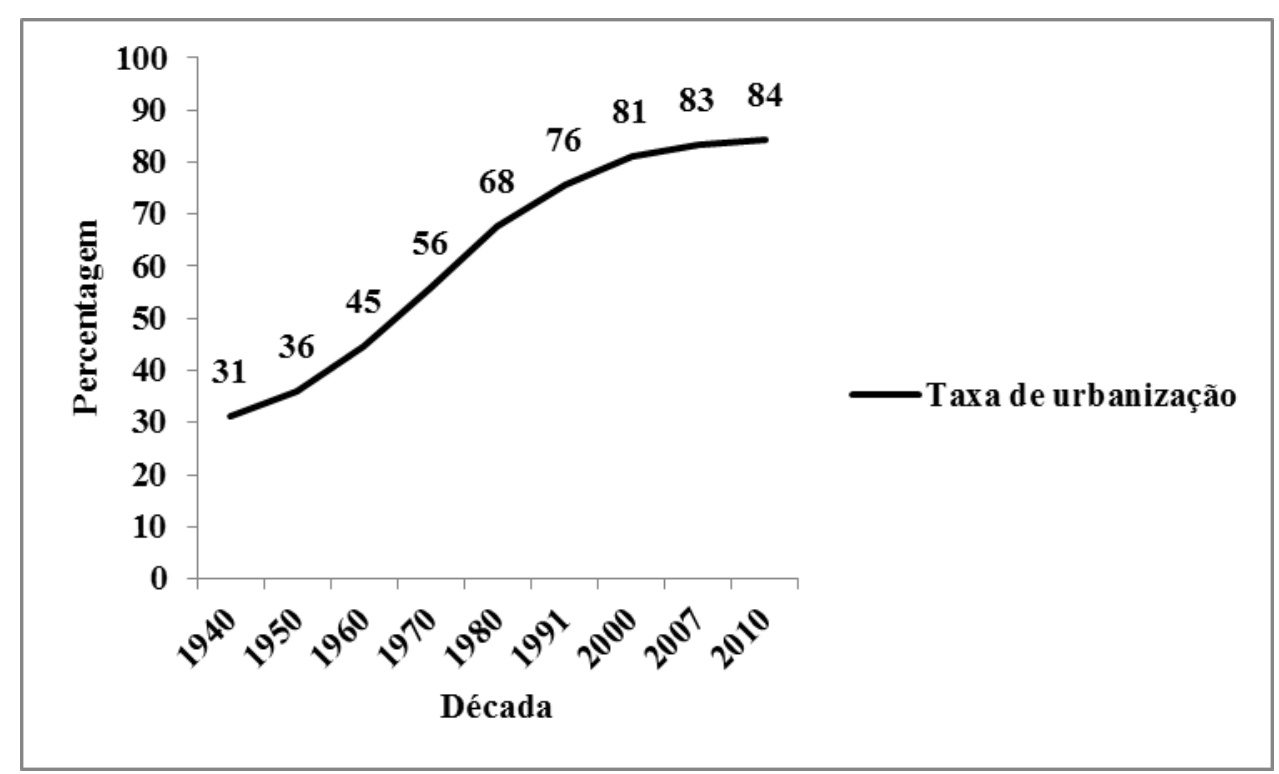

Gráfico 2 População por situação de domicilio (população presente e residente) (Fonte: Site do IBGE)

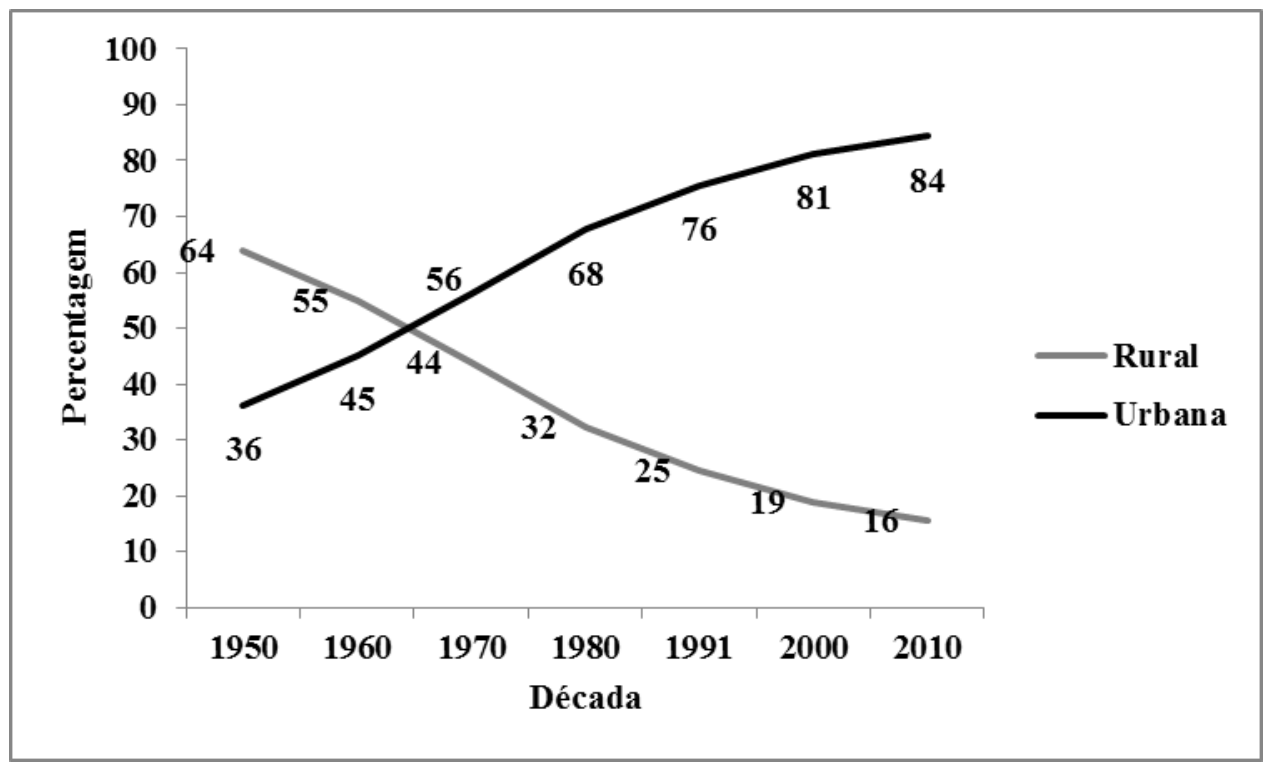


Em números absolutos, a população urbana saltou de 18 milhões na década de 1950 para 110 milhões em 1991, e no final da década de 1970, período em que o governo federal construíra 170.060 unidades habitacionais (de acordo com a tabela 1), a população urbana era de 52 milhões ${ }^{1}$. Além do pequeno atendimento proporcionado pela FCP, outra razão que explica o seu fracasso é a forte oposição que sofreu por alguns setores da sociedade: a indústria da construção civil temia que os esforços para construir 100 mil casas, objetivo da fundação, pudessem desviar recursos financeiros e insumos para outros projetos que não os dos IAPs. Bonduki (2002, p. 118, grifo nosso) menciona uma afirmação do presidente do Sindicato da Construção Civil:

Falta-nos cimento, tijolo, areia, pedra, enfim, todos os materiais de construção [...]. É comum faltar cimento no Rio de Janeiro por deficiência de vagões [...]. Como pensar em iniciar um grande plano de construção de casas populares se tudo nos falta, inclusive os meios para transportar os materiais.

Os próprios dirigentes dos IAPs eram contrários à $\mathrm{FCP}$, pois o seu sucesso enfraqueceria o poder político e econômico dos institutos, principalmente os mais ricos e importantes. Os setores contrários à FCP eram organizados e tinham capacidade para fazerem oposição, característica que não possuíam os grupos sociais que se beneficiariam com a realização do objetivo da fundação.

Por fim, além da coexistência dos IAPs e da FCP, a inexistência de recursos financeiros de origem não orçamentária, com um fluxo contínuo à fundação prejudicou também o sucesso do órgão, inviabilizando a meta de se construir 100 mil casas populares. Essa foi a principal causa do fracasso da Fundação Casa Popular, mas, além disso, havia a expectativa de que com o retorno financeiro dos investimentos, a FCP obtivesse uma autossuficiência financeira, sem depender de recursos orçamentários (ANDRADE;

1 As informações sobre os números absolutos da população estão no site do IBGE: http://seriesestatisticas.ibge.gov.br/ 
AZEVEDO, 1982, p. 24). Essa crença é visível pelo volume decrescente dos recursos orçamentários que deveriam ser aportados à fundação:

Tabela 2 Quantidade de recurso financeiro que seria aportada à FCP (Fonte: ANDRADE;

\begin{tabular}{|c|c|}
\hline \multicolumn{2}{|c|}{$\begin{array}{l}\text { Dotações orcamentárias da FCP, } \\
\text { instituídas pela Lei número } 1.473\end{array}$} \\
\hline $1^{\circ}$ Exercício & $\mathrm{Cr} \$ 200.000 .000,00$ \\
\hline $2^{\circ}$ Exercício & $\mathrm{Cr} \$ 180.000 .000,00$ \\
\hline $3^{\circ}$ Exercício & $\mathrm{Cr} \$ 160.000 .000,00$ \\
\hline $4^{\circ}$ Exercício & $\mathrm{Cr} \$ 140.000 .000,00$ \\
\hline $5^{\circ}$ Exercício & $\mathrm{Cr} \$ 120.000 .000,00$ \\
\hline $6^{\circ}$ Exercício & $\mathrm{Cr} \$ 100.000 .000,00$ \\
\hline $7^{\circ}$ Exercício & $\mathrm{Cr} \$ 80.000 .000,00$ \\
\hline $8^{\circ}$ Exercício & $\mathrm{Cr} \$ 60.000 .000,00$ \\
\hline $9^{\circ}$ Exercício & $\mathrm{Cr} \$ 40.000 .000,00$ \\
\hline $10^{\circ}$ Exercício & $\mathrm{Cr} \$ 20.000 .000,00$ \\
\hline
\end{tabular}

\subsection{A criação do Banco Nacional de Habitação no Regime Militar}

Os IAPs foram extintos em 1966, sendo substituídos pelo Instituto Nacional de Previdência Social (INPS), e a política habitacional federal foi transferida para o Banco Nacional da Habitação (BNH), criado em 1964 pela Lei 4.380. Em 1971, pela Lei 5.762, o Banco foi transformado em empresa pública, com personalidade jurídica de direito privado, detentora de patrimônio próprio. Junto com o $\mathrm{BNH}$ foi criado, pelo menos na teoria, um arranjo institucional diverso, com o qual o governo federal pretendia intervir no setor da habitação:

Art. $2^{\circ} \mathrm{O}$ Govêrno Federal intervirá no setor habitacional por intermédio: I - do Banco Nacional da Habitação;

II - do Serviço Federal de Habitação e Urbanismo;

III - das Caixas Econômicas Federais, IPASE, das Caixas Militares, dos órgãos federais de desenvolvimento regional e das sociedades de economia mista. (BRASIL, 1964a). 
A Lei 4.380 segue dizendo que caberia a esses órgãos coordenar, orientar e prover recursos financeiros, sendo que os entes federados ficariam responsáveis por elaborar seus planos diretores, projetos e orçamento para o enfrentamento dos problemas habitacionais. Por fim, a iniciativa privada promoveria a "execução de projetos de construção de habitações segundo as diretrizes urbanísticas locais” (BRASIL, 1964a).

Cabia ao $\mathrm{BNH}$, portanto, financiar ou refinanciar os projetos dos conjuntos habitacionais, seja por meio de bancos públicos ou privados, seja por meio de empresas públicas (como as companhias estaduais de habitação) ou privadas. Esse modelo é visto por Andrade e Azevedo (1982, p. 61) como uma inovação, pois a política habitacional passa a ser implementada por um banco dotado de amplos recursos financeiros. Estes são distribuídos para a iniciativa privada, que constrói os conjuntos habitacionais, ou seja, há pela primeira vez, no setor habitacional, uma articulação entre o setor público e privado para enfrentar o problema da precariedade habitacional. Os autores destacam também outra inovação: a aplicação de correção monetária nos contratos de empréstimo ao setor privado, e de financiamento habitacional ao mutuário final. Com efeito, o capítulo II da Lei 4.380 trata exclusivamente da correção monetária dos contratos imobiliários, estabelecendo que

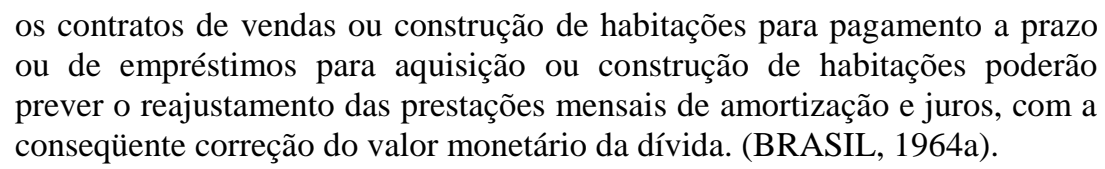

Porém, nem todas as inovações são necessariamente positivas, as quais justamente inviabilizaram parte do objetivo dos esforços do governo federal de atingir a população que vivia em "favelas, mocambos e outras aglomerações em condições sub-humanas de habitação" (BRASIL, 1964a). O BNH cometeu dois erros ao transferir a construção dos conjuntos para a iniciativa privada, e ao praticar uma taxa de correção monetária: o não reconhecimento "da fragilidade, enquanto mercado, da população à qual as COHABs se 
dirigiam inicialmente" (MARICATO, 1987, p. 45), e a preponderância de uma lógica de mercado, que não condizia com o atendimento das classes desfavorecidas financeiramente.

O reflexo dessa lógica de mercado está presente na premissa de uma empresa privada, segundo à qual "os investimentos sem retorno implicam a inevitabilidade da falência" (ARRETCHE, 1990, p. 30). Ora, como é possível para um/a cidadão/ã com baixa renda arcar com os custos de um financiamento habitacional, no qual está inserido taxas de retorno, de juros e correção monetária? Por isso, existia um "total descompasso entre os rendimentos da clientela popular [...] e as dívidas relativas ao financiamento da casa própria [...]" (MARICATO, 1987, p. 38). Como consequência, “a variável 'renda' seria o mecanismo de seleção para inserção nos diferentes programas habitacionais do BHN” (ARRETCHE, 1990, p. 33). Dessa forma, as classes que não alcançassem um limite e renda, permaneciam excluídas dos programas nacionais de habitação. Além disso, era proibido aos trabalhadores sem carteira assinada se inscreverem nos programas habitacionais, pois sem aquele documento não conseguiam comprovar renda e capacidade de pagamento. Tendo em vista que a informalidade do trabalho era alta nesse período, trabalhadores informais estavam fora da política habitacional federal.

Apesar desses equívocos cometidos pelo $\mathrm{BNH}$, a produção habitacional do período é impressionante, principalmente, quando comparada com o período anterior:

Tabela 3 Produção habitacional do período de 1964 a 1986 (Fonte: BONDUKI, 2014, p. 65).

\begin{tabular}{|c|c|c|c|c|c|c|c|}
\hline \multirow[t]{2}{*}{ Período } & \multirow[t]{2}{*}{ Presidente } & \multicolumn{4}{|c|}{ Habitação Popular } & \multirow[t]{2}{*}{ SBPE } & \multirow[t]{2}{*}{ Total Geral } \\
\hline & & COHAB & Outros & Cooperativas & Total Habitação Popular & & \\
\hline 1964-1969 & Castelo Branco e Costa e Silva & 178.895 & 64.727 & 61.223 & 304.845 & 120.469 & 425.314 \\
\hline 1970-1974 & Garrastazu Medici & 77.902 & 55.833 & 100.227 & 233.962 & 326.146 & 560.108 \\
\hline $1075-1979$ & Ernesto Geisel & 593.777 & 31.134 & 178.008 & 802.919 & 400.108 & 1.203.027 \\
\hline 1980-1984 & João Figueiredo & 655.888 & 112.842 & 156.493 & 925.223 & 972.366 & 1.897 .589 \\
\hline $1985-1986$ & José Sarney & 71.402 & 19.984 & 14.656 & 106.042 & 79.482 & 185.524 \\
\hline Total & & 1.577 .864 & 284.520 & 510.607 & 2.372 .991 & 1.898.571 & 4.271 .562 \\
\hline
\end{tabular}

Porém, é preciso ter em mente que a habitação popular diz respeito a uma a estratégia peculiar adotada pelo BNH para atender a população de baixo poder aquisitivo: se concentrar 
“nas faixas mais altas dos limites para os quais as COHABs se dirigiram" (MARICATO, 1987, p. 51), priorizando aqueles que estavam no limite da faixa salarial entre 3 e 5 salários mínimos. Se em 34 anos (entre 1930 a 1964) foram construídas 175.060 moradias, em 22 anos de BNH ergueram-se em torno de 4 milhões de moradia, ou seja, em termos de unidades habitacionais construídas ocorreu um avanço que não é desprezível. Contudo, conforme demonstra a tabela 4, os esforços financeiros para atingir a população com pequeno poder aquisitivo não foram grandes: a carteira de operações de natureza social deixou de receber metade dos recursos no ano de 1965, e a verba destinada àquela carteira diminuiu sucessivamente.

Tabela 4 Participação percentual dos financiamentos habitacionais concedidos pelo SFH através de contratos - Brasil - 1964/1975 (Fonte: MARICATO, 1987, p. 47)

\begin{tabular}{|l|c|c|c|c|c|c|c|c|c|c|c|c|c|c|}
\hline ÁREAS & ANOS & $\mathbf{1 9 6 4}$ & $\mathbf{1 9 6 5}$ & $\mathbf{1 9 6 6}$ & $\mathbf{1 9 6 7}$ & $\mathbf{1 9 6 8}$ & $\mathbf{1 9 6 9}$ & $\mathbf{1 9 7 0}$ & $\mathbf{1 9 7 1}$ & $\mathbf{1 9 7 2}$ & $\mathbf{1 9 7 3}$ & $\mathbf{1 9 7 4}$ & $\mathbf{1 9 7 5}$ & TOTAL \\
\hline COS & & 100 & 88,41 & 40,2 & 40,08 & 31,4 & 35,9 & 14,1 & 15,26 & 10,12 & 11,98 & 8,22 & 32,12 & 24,6 \\
\hline CPH & & - & 11,59 & 40,35 & 24,52 & 33,59 & 31,64 & 32,32 & 32,61 & 20,4 & 21,55 & 9 & 8,35 & 24,37 \\
\hline SBPE & & - & - & 19,45 & 28,91 & 33,18 & 26,05 & 46,85 & 42,95 & 56,44 & 50,81 & 60,62 & 45,1 & 41,59 \\
\hline RECON & & - & - & - & 0,49 & 1,83 & 6,41 & 6,64 & 9,18 & 13,03 & 15,66 & 22,16 & 9,37 & 8,86 \\
\hline PROFILURB & & - & - & - & - & - & - & - & - & - & - & - & 2,41 & 0,28 \\
\hline SFH(TOTAL) & & 100 & 100 & 100 & 100 & 100 & 100 & 100 & 100 & 100 & 100 & 100 & 100 & 100 \\
\hline
\end{tabular}

Outro ponto que deve ser destacado sobre a atuação do BNH é a sua ambiguidade, tal como ocorria com os IAPs, pois não era um banco exclusivo para o financiamento de projetos habitacionais, participando também do desenvolvimento e do financiamento da política urbana e de grandes projetos nacionais. Por isso, a distribuição de seus recursos financeiros não estava restrita apenas ao setor da habitação, que, durante os anos de 1969 a 1976, ficou em segundo plano, ao passo que os projetos de desenvolvimento urbano tiveram seus recursos ampliados anualmente (MARICATO, 1987, p. 37). Ademais, durante esse período, “os empreendimentos voltados à população de baixa renda se constituiu em estrondosos fracassos" (MARICATO, 1987, p. 42). 


\subsection{A extinção do BNH e os dois mandatos de Fernando Henrique (FHC)}

Uma das características marcantes desse período (1986 a 2001) é a pouca produção de unidades habitacionais com o envolvimento do governo federal, que só seria retomada no segundo mandado do ex-presidente Lula. Porém, esse período é importante devido às reformas (que fazem parte de um processo incremental de mudança) implementadas no setor da habitação, as quais possibilitaram a retomada da produção habitacional em larga escala (DIAS, 2012). Diante de um contexto de ausência do governo federal, os governos locais começaram a desenvolver suas próprias políticas habitacionais, que adquiriram um aspecto diferente das experiências anteriores: a unidade habitacional construída para a venda deixou de ser a única alternativa oferecida pelos programas habitacionais.

Assim, estados e municípios se empenharam na urbanização de favelas, na regularização de lotes clandestinos, no provimento de lotes urbanizados, nas reformas de cortiços e na locação social de imóveis (MARQUES, 2010, p. 4). Esse processo de inovação gerou um policy learning, que foi agregado, posteriormente, na política habitacional federal desenvolvida nos dois governos de Lula. A alta inflação que atingiu parte desse período foi outro agravante no setor da habitação e dificultou bastante a qualquer pessoa adquirir um imóvel, e também as próprias iniciativas locais de política públicas habitacionais:

Gráfico 3 Evolução histórica da média anual da inflação no setor da habitação, de acordo com o Índice nacional de preço ao consumidor, apenas a parte da Habitação (Fonte: IBGE)

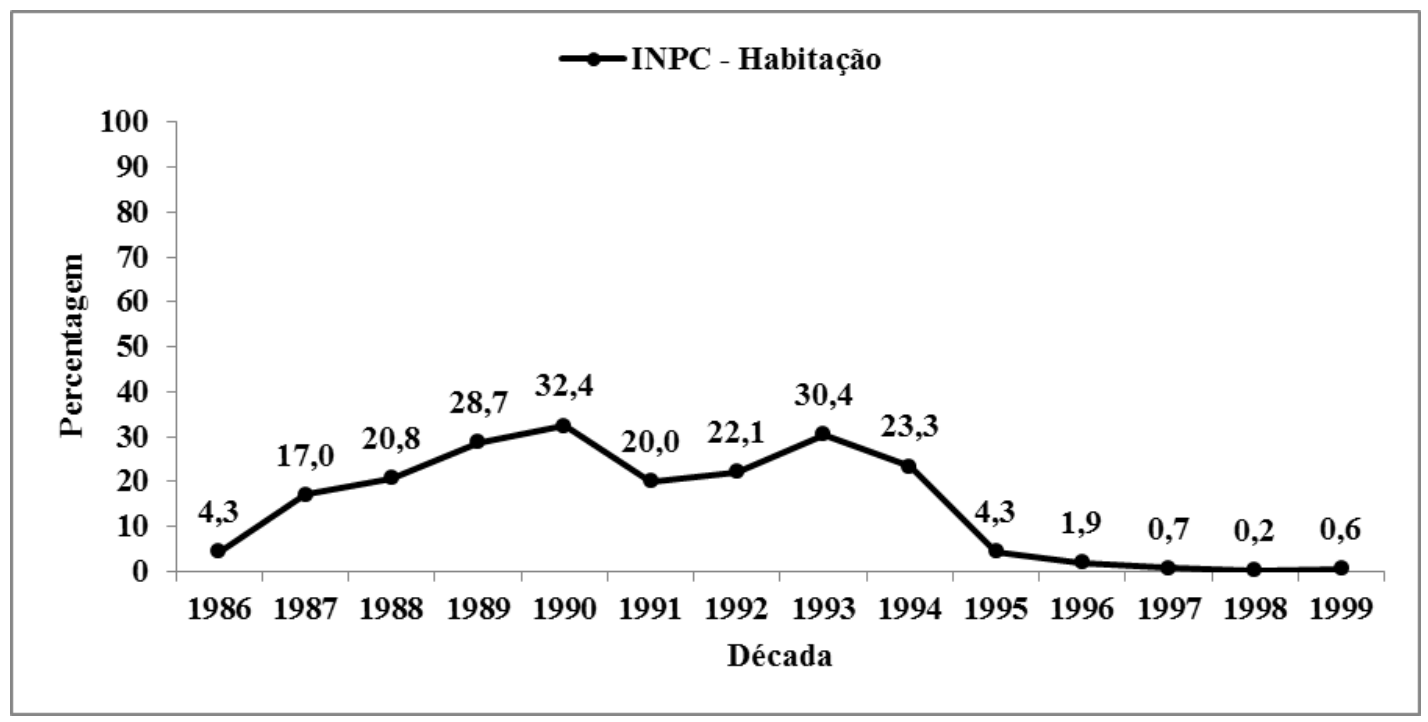


Desde a extinção do BNH, em 1986, durante 15 anos, a política nacional de habitação permaneceu orbitando em diversos ministérios ${ }^{2}$, e não ocorreram importantes mudanças no atendimento às classes de baixa renda. Com efeito, desde 1976 até o primeiro mandato de Fernando Henrique Cardoso (FHC), "os investimentos do SFH [Sistema Financeiro de Habitação] combinaram [...] interesses empresariais imobiliários e de proprietários fundiários com interesses clientelistas arcaicos" (MARICATO, 1998, p. 4). Mesmo durante o segundo governo de Cardoso, a política habitacional federal manteve a tendência de prestar pouca atenção à parcela de baixa renda da população.

Durante os anos de 1995 a 2002, ocorreram algumas mudanças no desenho dos programas habitacionais: o governo federal começou a desenvolver uma política de crédito para o mutuário final, e substituiu um modelo estatal e centralizado de construção habitacional, por um que descentralizava a alocação dos recursos e que introduzia mais princípios de mercado (ARRETCHE, 2002, p. 435). Além disso, é possível dizer que foi planejado um grupo de política habitacional destinada às classes baixas e outro às classes médias e altas.

No primeiro caso, o governo federal lançou em 1995 o programa Pró-moradia, que mantinha uma continuidade com o modelo anterior do $\mathrm{BNH}$, pois estabelecia, por meio de agentes públicos, a construção de unidades habitacionais novas para famílias que auferissem renda de até 3 salários mínimos. Além desse pacote habitacional, o governo de Fernando Henrique criou o Programa Carta de Crédito Individual (destinado à população de até 12 salários mínimos), cujo objetivo era o de financiar diretamente o mutuário final para que adquirisse imóveis já construídos.

\footnotetext{
2 Ministério da Habitação, Urbanismo e Meio Ambiente (1987); Ministério de Bem Estar Social (1988) e depois Ação Social (1990), Secretaria de Política Urbana ligada ao Ministério do Planejamento (1995) e Secretaria Especial de Desenvolvimento Urbano ligado ao gabinete da Presidência da República (1999) (ROLNIK, 2009, p. 4).
} 
Quando os resultados dessas duas políticas são comparados, fica evidente a pouca atenção que as classes baixas receberam durante 1994-2002: durante os anos de 1995-1998, apenas $11 \%$ foram investidos no Pró-moradia contra $75 \%$ na Carta de crédito Individual (ARRETCHE, 2002, p. 440). Maricato (1998, p. 7) apresenta valores semelhantes: “dos recursos do FGTS [...] inicialmente destinados às faixas de renda de 1 a $5 \mathrm{SM}$, apenas $13 \%$ foram investidos. [...] para investimento nas faixas de renda situadas entre 5 e $12 \mathrm{SM}$, foram investidos 107\%”. Bonduki (2014) sistematiza esses dados de maneira comparativa:

Tabela 5 Número de contratos e valor financiado com recursos do FGTS por programas Brasil (1995-2003) (Fontes: BONDUKI, 2014, p.103)

\begin{tabular}{|c|c|c|c|c|c|}
\hline & Programas & $\begin{array}{c}\text { Valor Contratado } \\
\text { (em milhões de } \\
\text { reais) }\end{array}$ & $\%$ & $\begin{array}{c}\text { Número de contratos } \\
(\text { em mil })\end{array}$ & $\%$ \\
\hline \multirow{5}{*}{$\begin{array}{c}\text { Programas } \\
\text { para } \\
\text { construção } \\
\text { de UH }\end{array}$} & Programa/Modalidade & & & & \\
\hline & PAR & 2.344 & 10,5 & 106 & 6,3 \\
\hline & Pró-moradia & 884 & 3,9 & - & - \\
\hline & Apoio à proução & 55 & 0,01 & 4 & 0,01 \\
\hline & Carta de crédito as sociativa & 4.109 & 18,4 & 180 & 10,7 \\
\hline \multirow{5}{*}{$\begin{array}{l}\text { Carta de } \\
\text { crédito } \\
\text { individual }\end{array}$} & Aquisição de usado & 9.284 & & 523 & \\
\hline & Material de construção & 2.095 & & 567 & \\
\hline & Aquisição de novo & 1.418 & & 74 & \\
\hline & Outros & 2.086 & & 222 & \\
\hline & Total & 14.883 & 66,8 & 1.386 & 82,7 \\
\hline Total geral & & 22.275 & 100 & 1.676 & 100 \\
\hline
\end{tabular}

O programa Pró-Moradia e o Programa de Arrendamento Residencial, destinados às famílias com pequeno poder aquisitivo, somam $14 \%$ dos recursos contra $66 \%$ de todos os programas ligados à carta de crédito individual.

Porém, a importância do período FHC para a política habitacional não está na quantidade de unidades produzidas, mas sim nas mudanças e nos programas que foram criados nesse período, bem como o controle da inflação: o PAR, apoio à produção, carta de crédito associativo, material para construção, e aquisição de imóvel novo são todos programas integrantes do Programa Minha Casa, Minha Vida (PMCMV). Esses são dois elementos que compõem o processo incremental de mudanças necessárias para que na década de 2000 
houvesse a retomada da produção de habitação em larga escala. Dias (2012, p. 26) destaca mais dois pontos:

\footnotetext{
a. Presença de um sistema habitacional (sistema de financiamento constituído nos governos militares),

b. Reformas que conferiram maior segurança jurídica ao sistema de financiamento, recuperação da capacidade de fundos, políticas de estímulo ao crédito e à produção, rearticulação organizacional/burocrática da política, alocação intensiva de subsídios.
}

Além do Plano Real (1994), foi criado no período FHC: o Sistema de Financiamento Imobiliário (SFI) (pela Lei 9.514 de 1997), o já mencionado PAR (pela medida provisória 1.823 de 1999), o Estatuto da Cidade (pela Lei 10.257 de 2001), o Programa de Subsídio à Habitação de Interesse Social (PSH) (pela medida provisória 2.212), e por fim, a resolução 3.005 do Banco Central promoveu a restauração dos recursos financeiros do Sistema Brasileiro de Poupança e Empréstimo (SBPE) (DIAS, 2012, p.39). Todas essas mudanças são inovações importantes, mas a criação de um programa de subsídio demonstra que o governo federal passou a reconhecer a fragilidade financeira de parte da população, a qual não só seria atendida por uma política habitacional justamente se houvesse subsídio.

\subsection{A década de 2000 e a criação do Programa Minha Casa, Minha Vida}

Em 2001 foi promulgada a Lei 10.257, conhecida também como Estatuto das Cidades, cujo objetivo era o de regulamentar os artigos 182 e 183 da Constituição Federal, os quais discorrem sobre a função social da propriedade nas cidades. Outro avanço foi a criação do Conselho Nacional de Desenvolvimento Urbano (CNDU), por meio da Medida Provisória 2.220 de 2001. Quando a gestão de Luís Inácio Lula da Silva (Lula) iniciou, foi criado o Ministério das Cidades, no qual estão reunidas quatro secretarias para o planejamento de políticas urbanas: Secretaria Nacional de Habitação (SNH), Secretaria Nacional de 
Saneamento Básico (SNSB), Secretaria Nacional de Transporte da Mobilidade Urbana (SNTMU), e Secretaria Nacional de Acessibilidade e Programa Urbanos (SNAPU).

Em 2003 foi realizada a primeira Conferência das Cidades, que se repetiu em 2005 e em 2007, e seu objetivo era o de debater questões e problemas urbanos das cidades para se pensar em soluções políticas. Na primeira conferência, o tema central era como formular uma Política Nacional de Desenvolvimento Urbano, atrelando as diversas políticas setoriais (de habitação, de saneamento básico, de mobilidade), e buscando garantir o cumprimento da função social da cidade e da propriedade e o acesso universal à moradia digna, combater à segregação sócio espacial, entre outros. O marco da segunda conferência é a ênfase dada à necessidade de se fazer política urbana baseada na gestão democrática, na participação e no controle social. Por fim, a terceira conferência enfatizou novamente a importância de se avançar na construção de uma Política Nacional de Desenvolvimento Urbano, de um Sistema Nacional de Desenvolvimento Urbano, além de criar uma Política de Regularização Fundiária.

A mesma Lei que criou o BNH, em 1964, instituiu o Sistema Financeiro de Habitação (SFH), o qual ainda existe, e por mais que houvesse no texto da Lei referência ao atendimento das classes de menor renda (famílias que ganhavam menos de $3 \mathrm{SM}$ ), esse alvo nunca foi atingido pelo SFH ou pelo BNH. Em 2005 a Lei 11.124 criou o Sistema Financeiro de Habitação de Interesse Social (SFHIS) e o Fundo Nacional de Habitação de Interesse Social (FNHIS), ambos responsáveis, como os próprios nomes dizem, em atender exclusivamente as famílias que se enquadrem na aquisição de habitação de interesse social. Ademais, o PSH foi regulamentado pela Lei 10.998 de 2003, pelo Decreto 5.247 de 2004, e pela Portaria Interministerial 335 de 2005, e seu objetivo é viabilizar o acesso à moradia para famílias que auferem renda de até $\mathrm{R} \$ 900,00$. 
Durante a década de 2000 foram publicados também dois documentos importantes para o setor da habitação e para o enfrentamento do déficit habitacional urbano: em 2004, o governo federal publicou a Política Nacional de Habitação (PNH), o qual estabelecia princípios, metas, diretrizes e objetivos que deveriam guiar a política habitacional federal. Em 2009, após longo trabalho e debate do Consórcio Via Pública/Fupam-LAHAB/Logos Engenharia, realizados nos anos antecedentes, foi publicado o Plano Nacional de Habitação (PlanHab), o qual incorporava a essência da PNH, e das discussões realizadas nas três conferências, para propor medidas mais objetivas sobre como equacionar o problema do déficit habitacional e da precariedade habitacional.

Uma das características do PlanHab é considerar a complexidade e as diversas faces daqueles dois problemas sociais, para propor um plano de ação com diversas soluções em quatro diferentes áreas: financiamento e subsídio, arranjos institucionais, estratégias urbanas e fundiárias, e cadeia produtiva da construção civil. Cada eixo é subdivido em outros temas e ações especificas, que devem ser implementadas num prazo de 15 anos. Tanto a PNH, como o PlanHab enfatizam que a construção de unidade habitacional nova para a venda não é a única solução possível e viável para cada realidade local: cidades poucas, com população urbana inferior a 100 mil habitantes, possuem dinâmica do mercado de terra urbana, uma demanda por habitação, e problemas habitacionais diferentes de uma cidade com mais de 400 mil habitantes, ou mesmo de uma região metropolitana. Por isso, cada caso deve ter um conjunto de soluções diferentes.

Nesse contexto de intenso debate sobre soluções para o déficit e a precariedade habitacional, e também com diversas iniciativas municipais para enfrentar esses dois problemas, com a tônica de que unidade nova para a venda não deve ser a única solução, surge o PMCMV. Este oferece uma única solução aos problemas habitacionais: justamente a construção de unidade nova para a venda. Seu objetivo inicial era construir 1 milhão de 
moradias em todo o Brasil para famílias com renda mensal de até 10 salários mínimos, para reduzir o déficit habitacional dessa faixa. Além disso, o programa pretendia aquecer a economia nacional e enfrentar a crise internacional de 2008, gerando emprego e renda.

O PMCMV possui algumas semelhanças com a política habitacional implementada pelo BNH. Como este, o programa viabiliza como principal solução para o problema do déficit habitacional a construção de unidade nova para venda por meio do setor privado. Por isso, é possível afirmar que tal como o BNH, o MCMV aposta na articulação entre o poder público e agentes privados, estratégia esta inovadora na década de 1960. Ademais, uma das atribuições da CEF é coordenar, orientar e prover recursos financeiros para as instituições financeiras interessadas em participar do PMCMV. Por fim, novamente um banco federal é o responsável pela implementação da política habitacional do país.

Talvez, se um estudo comparativo fosse feito, outras semelhanças surgissem, e apesar disso é possível afirmar que as dissemelhanças são superiores, fato que torna o PMCMV uma política habitacional distinta daquela que foi implementada pelo BNH. A primeira diferença a ser destaca é a existência de um mecanismo explícito de subsídio para famílias com renda mensal de até 6 salários mínimos. Inicialmente, as famílias que auferiam renda de até 3 salários mínimos pagavam parcelas fixas de $10 \%$ do valor da renda mensal, ou no mínimo R\$ 50,00 mensais (no caso dos $10 \%$ comprometer a renda mensal da família). Esses valores foram alterados posteriormente para $5 \%$ do valor da renda mensal, e parcela mínima de $\mathrm{R} \$$ 25,00, durante 10 anos.

Por exemplo, uma família cuja renda mensal seja R \$ 1.600,00 (valor limite da faixa 1, até 3 salários mínimos), pagará parcelas de R\$ 160,00 durante 10 anos. Caso o imóvel esteja localizado na Região Metropolitana de São Paulo, o valor da venda será 96 mil, portanto, o governo federal dará um subsídio de $\mathrm{R}$ \$76.800,00 e a família pagará apenas $\mathrm{R}$ \$19.200,00, ou seja, a família pagaria $20 \%$ do valor do imóvel e os $80 \%$ restantes seriam subsidiados pelo 
Estado. O subsídio para famílias com renda mensal entre 3 e 6 salários mínimos é significativamente inferior e mais difícil de se calcular, porque a CEF usa diversas fórmulas que variam de acordo com a renda familiar mensal, mas o valor máximo concedido era de 23 mil, elevado para 25 mil (pelo Decreto 7.825 de 11 de outubro de 2012). Além disso, a quantidade do subsídio que a CEF aprova é inversamente proporcional a renda mensal da família, ou seja, quanto mais próximo de $\mathrm{R} \$$ 3.275,00 (valor limite da faixa 2, até 6 salários mínimos), menor será o valor concedido pela CEF. No caso de uma família receber o valor máximo, e do imóvel custar 190 mil (valor limite para venda de unidade habitacional em região metropolitana), $13 \%$ será subsidiado pelo governo federal.

O mecanismo de subsídio ajuda a garantir que as unidades habitacionais construídas se destinem para as famílias, cuja renda mensal é de até 3 salários, ao contrário do que ocorria no $\mathrm{BNH}$, quando o discurso dizia que aquela parcela da população era atendida, mas na prática priorizava-se o limite superior: famílias que ganhavam entre 3 e 5 salários. Se somarmos a quantidade de recursos destinados para famílias que ganham até 6 salários, com os alocados no FGHab, pode-se afirmar que na fase 1 do PMCMV (de 2009 a 2011,) 82\% destinavam-se para habitação de interesse social, e habitação de mercado popular. Esse porcentual só foi tão elevado assim em 1965, mas no ano seguinte reduziu-se pela metade, e no período FHC, aproximadamente 3.2 bilhões foram destinados à habitação social e popular, valor superior aos 16 bilhões. Portanto, a quantidade de recursos que o MCMV e o modo que isso foi feito são diferentes da experiência do BNH e do período subsequente a sua extinção.

Tabela 6 Destino do recurso financeiro da primeira fase do PMCMV (Fonte: MCidades/SNH/DHAB. In: BRASIL, 2010a, p. 52)

\begin{tabular}{|l|r|}
\hline Atendimento & R\$ bilhões \\
\hline Subsídio à moradia, renda até R\$ 1.395,00 & 16 \\
\hline Subsídio e financiamento à moradia, renda de até R\$ 2.790,00 & 10 \\
\hline Financiamento à Infraestrutura & 5 \\
\hline Fundo Garantidor de Habitação - FGHAB & 2 \\
\hline Financiamento à Cadeia Produtiva & 1 \\
\hline TOTAL: & $\mathbf{3 4}$ \\
\hline
\end{tabular}




\subsection{Conclusão}

O Minha Casa, Minha Vida produz habitação, articulando o poder público (a prefeitura), um banco (a Caixa Econômica) e o setor privado (as empresas de construção civil), mas disso não decorre necessariamente que os interesses privados prevalecem, ou ainda que o programa possui um caráter mercadológico. Isto porque, na faixa 1 , existe um mecanismo de subsídio explícito, uma política de zero juro no financiamento habitacional, isenção dos custos cartoriais e acesso ao Fundo Garantidor da Habitação. O que é diferente da experiência da Fundação Casa Popular quando era praticado o retorno financeiro dos empreendimentos, e pouco recurso financeiro era destinado à fundação, ou mesmo do $\mathrm{BNH}$, que dispunha de amplos recursos federais, mas praticava também o retorno financeiro dos empreendimentos, bem como taxas de juros e correção monetária nos financiamentos habitacionais aos mutuários finais. 


\section{Capítulo 2 O que é o PMCMV?}

Esta dissertação de mestrado endossa a tese proposta por Dias (2012), segundo a qual o PMCMV é resultado de um processo de mudanças incrementais, iniciado com a criação do Sistema Financeiro de Habitação (SFH) ainda no regime militar. Por isso, o MCMV reúne programas e linhas de financiamentos que já existiam anteriormente: apoio à produção, carta de crédito associativo (que recebe o nome comercial de imóvel na planta), carta de crédito individual (que recebe o nome comercial de aquisição de imóvel novo), material de construção. Esses são alguns dos programas que compõem o Programa Nacional de Habitação Urbana $(\mathrm{PNHU})^{3}$, no qual estão inclusos ainda as unidades construídas para famílias que ganham até 3 salários, o PAR-faixa 1, e as construídas por intermédio de movimentos de moradia, o FDS-entidades.

O objetivo deste capítulo é fazer uma primeira descrição sobre a forma do PMCMV, a qual será aprofundada no capítulo 3, analisar a produção da habitação e o atendimento do déficit habitacional em nível nacional. Para a literatura crítica, existia um ceticismo com relação à redução do déficit na faixa 1, pois o programa não estaria ajustado de acordo com as faixas de renda do déficit, ou seja, não haveria um alinhamento entre o Minha Casa Minha Vida e a realidade brasileira da falta e precariedade de habitação.

$\mathrm{Na}$ verdade, analisar o atendimento do déficit é mais complexo do que a simples operação de comparar a quantidade de unidades produzidas pelo programa para a faixa 1 e o déficit na faixa 1. Isto porque, o estudo do déficit realizado pela Fundação João Pinheiro sofreu algumas alterações ao longo da década de 2000. Ademais, o déficit da faixa 1 é proporcionalmente muito maior do que na faixa 2 e 3 , o que dificulta o objetivo de redução,

\footnotetext{
3 O PMCMV ainda é composto pelo Programa Nacional de Habitação Rural (PNHR), mas que não constitui objeto de estudo desta dissertação de mestrado, pois o déficit habitacional rural (5.496 famílias em 2010) da Região Metropolitana de São Paulo é pequeno comparado com o urbano (787.552)
} 
mas também há famílias que pertencem à faixa 1 , mas migram para a faixa 2, pois assim podem escolher a sua moradia, e não precisam esperar na fila do cadastro realizado pelas prefeituras. Outro problema das faixas é que existem famílias que compraram unidades da faixa 2 ou da faixa 3 como forma de investimento e não para constituir um novo lar, e isso faz com que a unidade construída pelo PMCMV para faixa 2 e 3 não reduza diretamente o déficit habitacional.

Por fim, a estratégia de comparar a produção habitacional do programa na faixa $1 \mathrm{com}$ o déficit habitacional urbano brasileiro reduz a realidade de tal modo a esconder as nuances do atendimento do déficit. Há estados que o déficit na faixa 1 atendido é grande, mas, ao mesmo tempo, há situações em que o déficit nas faixas 2 e 3 foi quase zerado. Portanto, por mais que o PMCMV tenha priorizado a construção de empreendimentos para a faixa 1, há casos em que esses esforços não foram suficientes, gerando um atendimento do déficit desproporcional à realidade das necessidades habitacionais.

\subsection{Aspectos gerais do PMCMV}

O objetivo geral do programa quando foi lançado pode ser subdividido em pelo menos três metas: incentivar a aquisição, a produção, e a requalificação de imóveis urbanos, e no meio rural, a produção ou a reforma das habitações. Para explicar como o pacote habitacional pretendeu alcançar esses objetivos é preciso descrever algumas de suas regras, que foram estabelecidas por leis, portarias, resoluções e instruções normativas. Desde a criação do programa, a Lei 11.977 de junho de 2009 foi alterada três vezes: pelas Leis 12.424 de 2011, 12.693 de 2012, e 12.868. Ademais, as portarias que regulamentam os financiamentos realizados pelo Fundo de Arrendamento Residencial (FAR) e pelo Fundo de Garantia por 
Tempo de Trabalho e Serviço (FGTS) foram alteradas anualmente. Essas constatações evidenciam que o PMCMV é uma política pública em constante alteração, fato que dificulta a análise empírica dos empreendimentos, pois as regras que valiam em 2010 não eram as mesmas de 2012. Mesmo uma análise descritiva de como o programa funciona é dificultada, pois o PMCMV de 2011 que é descrito difere-se do de 2013 - por exemplo, não havia o Minha Casa Melhor, linha de crédito para as famílias financiarem eletrodomésticos.

Esta seção visa encontrar uma descrição do programa que possa transcender essas diferenças de regras, de tal modo a tornar inteligível o programa para uma análise empírica. Primeiramente, a Lei 11.977 de 2009 corresponde à fase 1 do programa, ao passo que a Lei 12.424 de 2011 criou o PMCMV II, e alterou de maneira mais significativa a fase 1 do programa, fazendo com que o PMCMV passasse a ser composto apenas pelo Programa Nacional de Habitação Urbana (PNHU) e pelo Programa Nacional de Habitação Rural (PNHR). Ademais a Lei de 2011 trouxe conceitos importantes (grupo familiar, imóvel novo, requalificação de imóvel) para a implementação do MCMV, os quais não estavam claramente definidos na Lei de 2009.

O incentivo à construção, à aquisição e à requalificação de imóveis urbanos são objetivos do PNHU, e além do FAR e do FGTS, esse subprograma do MCMV conta com o Fundo de Desenvolvimento Social (FDS), e o Fundo Garantidor da Habitação (FGHab): essas são as três fontes de recursos financeiros destinados para alcançar o objetivo do PNHU. Porém, a maneira que o governo federal destina recursos para esses três fundos difere: para o FGTS, a União concede subvenção econômica para subsidiar o financiamento habitacional de famílias que ganham até $\mathrm{R} \$ 2.790,00$. Isso significa que o FGTS utiliza seus próprios recursos para tal finalidade, e posteriormente o governo federal destina a quantidade necessária para cobrir o déficit gerado, acrescido da remuneração à gestora do FGTS, a Caixa Economia Federal (CEF). 
Já com relação ao FAR a União participa por meio de integração de cotas, e transfere recursos para o FDS, ambos os fundos têm como gestora também a CEF, que recebe remuneração estabelecida pelo poder executivo pelos serviços desempenhados. Do ponto de vista fiscal e da organização das contas públicas, há diferença conceitual entre subvenção, integração e transferência, mas na prática a União está concedendo recursos não reembolsáveis para esses três fundos subsidiar a aquisição de imóveis novos pelas famílias com renda mensal de até $\mathrm{R} \$ 2.790,00$. Em outras palavras, os subsídios destinados à faixa 1 são oriundos do FAR e do FDS (neste caso, quando é uma entidade que está participando do programa), e os da faixa 2, são de origem do FGTS.

Com relação ao mecanismo de subsídio, é necessário fazer uma ressalva: um dos aspectos que se alterou com a evolução do PMCMV foi justamente o critério que delimitava as faixas de atendimento que o programa focava. Em 2009, falava-se em faixa 1, 2 e 3, delimitadas respectivamente por salários mínimos: de 0 a 3, de 3 a 6 , e de 610 . Gradualmente, as regras do MCMV alteraram para faixas de renda nominal. A tabela a seguir resume essas mudanças:

Tabela 7 Resumo das informações principais sobre as faixas de atendimento (Fonte: legislação sobre o PMCMV)

\begin{tabular}{|c|c|c|c|}
\hline & \multicolumn{3}{|c|}{ Critérios de elegibilidade } \\
\hline & $\begin{array}{c}\text { PMCMV I (Lei } 11.977 \text { de } \\
\text { 2009) } \\
\end{array}$ & $\begin{array}{c}\text { PMCMV II (Lei 12.424 de } \\
\text { 2011) } \\
\end{array}$ & Benefícios \\
\hline Faixa 1 & 0 a 3 SM, ou até $\mathrm{R} \$ 1.395,00$ & $\begin{array}{c}\text { Renda bruta familiar de até } \mathrm{R} \$ \\
1.600,00\end{array}$ & $\begin{array}{l}\text { No míninmo } 80 \% \text { de subsídio, } \\
\text { no caso do imóvel custar } 96 \\
\text { mil; aces so ao FGHab; } \\
\text { isenção de custos cartoriais }\end{array}$ \\
\hline Faixa 2 & 3 a 6 SM, ou até $\mathrm{R} \$ 2.790,00$ & $\begin{array}{c}\text { Renda bruta familiar de até } \mathrm{R} \$ \\
3.100,00 \text { (Decreto } 7.499 \text { de } \\
\text { 2011), e até } \mathrm{R} \$ 3.275,00 \\
\text { (Decreto } 7.825 \text { de 2012) }\end{array}$ & $\begin{array}{c}\text { Subsídio de no máximo R\$ } \\
\text { 25.000; acesso ao FGHab; } \\
\text { descontos nos custos } \\
\text { cartoriais; juros reduzido }\end{array}$ \\
\hline Faixa 3 & 6 a 10 SM, ou até $\mathrm{R} \$ 4.900,00$ & \begin{tabular}{|c|} 
Renda bruta familiar de até R\$ \\
$5.000,00$ (Decreto 7.499 de \\
2011), elevado em RM até R\$ \\
5.400,00 (Instruções \\
Normativas 33 e 35 de 2012)
\end{tabular} & $\begin{array}{l}\text { Acesso ao FGHab; juros } \\
\text { reduzidos; descontos nos } \\
\text { custos cartoriais }\end{array}$ \\
\hline
\end{tabular}


É importante diferenciar as operações de financiamento habitacional que contém subsídio, das que não possuem (realizado por famílias que estão além da faixa 2), e também dos financiamentos que a CEF faz, no âmbito do programa, para as empresas de construção civil. Conforme mencionado anteriormente, o PMCMV, por meio da PNHU, incentiva a aquisição, a produção e a requalificação de unidade habitacional. Existem duas maneiras de alcançar esses objetivos: um/a cidadão/ã decide pleitear um financiamento habitacional na CEF. Caso decida por uma unidade habitacional construída fora do PMCMV, é preciso que seu preço de venda esteja dentro do limite estabelecido pelo MCMV para o município em que reside, e que o habita-se, ou documento equivalente, tenha sido expedido em no máximo 180 dias. Nesse cenário, o/a cidadão/ã solicita um financiamento habitacional enquanto pessoa física $(\mathrm{PF})$, e se for elegível, receberá o subsídio inversamente proporcional a sua renda mensal. Esse é a aquisição de imóvel novo, produto oferecido pela $\mathrm{CEF}$, que na prática é uma linha de crédito para financiamento habitacional, regulamentada pela Instrução Normativa 30, de 15 de outubro de 2012.

Ainda no âmbito da PF, nosso cidadão/ã pode escolher solicitar um financiamento para construir a sua moradia, objetivo contemplado pelo PMCMV, e solicita à Caixa os recursos, por meio do produto construção individual, obtendo o subsídio, caso se enquadre no perfil (novamente a Instrução Normativa 30 também regulamenta essa linha de financiamento). Por fim, esse/a cidadão/ã hipotético pode possuir um ímpeto mais empreendedor e decidir construir, por meio da alocação de recursos, um empreendimento, cujas unidades serão comercializadas pelo PMCMV. Todos esses produtos possuem regras específicas estabelecidas por portarias e leis, mas a características comuns dos três é que compete à pessoa física solicitar o recurso financeiro para Caixa, que analisa a proposta, e enquadra os solicitantes nas faixas de renda, aprovando-a ou recusando-a. Não há então 
financiamento da CEF para empresas de construção civil para a construção de empreendimentos imobiliários.

Tabela 8 Comercialização (em UH) de moradia pelo PMCMV-PF, fases 1 e 2 do programa (Fontes: dados da CEF trabalhados pelo CEM) - até junho de 2014

\begin{tabular}{|l|r|r|r|r|}
\hline \multicolumn{1}{|c|}{ Produto } & $\begin{array}{c}\text { Faixa 2 - Até R\$ } \\
\mathbf{1 . 6 0 0 , 0 0}\end{array}$ & $\begin{array}{c}\text { Faixa 2 - De R\$ 1.600,00 } \\
\text { à R\$ 3.250,00 }\end{array}$ & $\begin{array}{c}\text { Faixa 3 - De R\$ 3.250,00 } \\
\text { à R\$ 5.000,00 }\end{array}$ & Total \\
\hline Alocação de Recursos & 624 & 1.731 & 919 & 3.274 \\
\hline Apoio à Produção & 157 & 569 & 413 & 1.139 \\
\hline Aquisição Imóvel Novo & 3.517 & 11.339 & 3.804 & 18.660 \\
\hline Construção Individual & 4.213 & 12.288 & 3.157 & 19.658 \\
\hline Imóvel na Planta & 138 & 319 & 182 & 639 \\
\hline $\begin{array}{l}\text { Programa Nacional de } \\
\text { Habitação Rural }\end{array}$ & - & 18 & - & 18 \\
\hline Total & 8.650 & 26.264 & 8.475 & 43.389 \\
\hline
\end{tabular}

Conforme a tabela 8 demonstra, os dois principais produtos da parte PF do programa são a aquisição de imóvel novo (43\% do total da comercialização) e a construção individual (45\% do total da comercialização). A faixa de renda que mais adquiriu moradia por meio dessas duas linhas de financiamento foi a faixa 2 (entre $\mathrm{R} \$ 1.600,00$ e $\mathrm{R} \$ 3.250,00)-60 \%$ do total da comercialização. Cabe destacar que a faixa 2 até $\mathrm{R} \$ 1.600,00$, são famílias que se enquadrariam na faixa 1 , mas optam pelo financiamento na faixa 2 , por desejarem escolher o imóvel, para evitar as extensas filas das pessoas já cadastradas que esperam pelo sorteio das prefeituras, entre outras razões.

Os três produtos exclusivamente destinados para PF não farão parte da análise desta dissertação, pois não existe relação entre CEF e empresas de construção civil, tampouco, entre CEF e prefeitura. A exceção seria a alocação de recursos que permite a pessoas jurídicas realizarem financiamento para construção por meio do MCMV, mas não foram realizados nenhum empreendimento PJ por meio da alocação de recursos. Além disso, a produção de moradia que foi comprada pela parte do PF do programa é pouca quando comparada com a PJ: esta construiu 2.120.362 unidades, enquanto aquela viabilizou a compra de 43.389 moradias, até junho de 2014 - a PJ representa 97\% do programa, enquanto a PF apenas 3\%. 
Por fim, não há dados sobre os endereços dos empreendimentos que tiveram unidades habitacionais comercializadas pelos produtos PF da Caixa, o que inviabiliza o estudo da segregação desses imóveis.

\subsection{O PMCMV Pessoa Jurídica}

A segunda maneira de incentivar a construção, a aquisição e a requalificação de moradia é por meio das empresas de construção civil, e é essa parte do programa que possui a participação de mais atores na implementação do PMCMV. Os três principais produtos dessa parte do programa são: Far-faixa 1, Imóvel na planta e Apoio a Produção (faixas 2 e 3). A Portaria 168 (para faixa 1 - FAR) e a Instrução Normativa 33 (para apoio à produção- faixas 2 e 3), e a Instrução Normativa 35 (para imóvel na planta - faixas 2 e 3 ) estabelecem quais são os atores e suas funções, bem como a Lei 12.424, e outros Decretos-lei, e resoluções ${ }^{4}$. Na faixa 1- FAR, ao Ministério das Cidades compete funções mais gerais sobre as regras do programa e seu funcionamento, tais como: definir tipologia das casas e apartamentos; remanejar os recursos do programa, se necessário; fixar em conjunto com os Ministérios da Fazenda e do Planejamento, Orçamento e Gestão, a remuneração da Caixa Econômica Federal pelas atividades exercidas no âmbito das operações; regular a participação dos entes da federação, por meio dos termos de adesão que cada um assinou.

A Caixa Econômica Federal (CEF) desempenha dois papéis: um de agente gestor (AG) e outro de agente financeiro (AF). Enquanto agente gestora, cabe a CEF expedir atos

\footnotetext{
4 De fato, as regras do PMCMV são dispersas em diversos documentos jurídicos, que são promulgados pelo poder executivo e pela CEF. Há também as regras que valem para a construção do empreendimento, que dizem respeito sobre as Leis de uso do solo, as Leis sobre infraestrutura urbana para habitação de interesse social, etc. Por se tratar de um tema complexo e extenso, seria necessário um estudo exclusivo sobre isso, que levasse em conta a evolução do quadro legal do MCMV.
} 
normativos que digam respeito à operacionalização do PMCMV, gerir o FAR e FDS, e cadastrar, autorizar e remunerar outros agentes financeiros que queiram participar do programa. Porém, a Caixa também é um agente financeiro, junto com o Banco do Brasil $(\mathrm{BB})^{5}$, que é o executor do programa, ou seja, cabe aos AFs aprovarem os projetos de empreendimentos de acordo com as diversas regras. Além disso, o agente financeiro adquire, em nome do FAR, as unidades habitacionais destinadas à alienação, o que significa que o FAR não é o proprietário direto das unidades, mas sim os agentes financeiros. Isso possibilita que o morador seja o proprietário desde o início, e não após 15 anos (como era com o PAR), e é estratégico para a Caixa e para o FAR não serem detentores de toda a produção habitacional.

Cabe às empresas da construção civil construir os empreendimentos de acordo com as regras, e aos entes federativos assinarem um termo de adesão ao programa. Além disso, são as prefeituras que cadastram e sorteiam as famílias que serão beneficiadas pelo programa, bem como estabelecem critérios adicionais de elegibilidade ao programa aos que já foram definidos pelo Ministério das Cidades. Deve-se destacar que o FAR-faixa 1 possui presença maior do poder público (seja federal, seja estadual ou municipal), do que os outros produtos para faixa 2 e 3, os quais possuem características da produção habitacional de mercado. Esta diferença ficará mais clara no capítulo 2, no qual é analisado com mais detalhes as regras desses programas.

Nos dois programas das faixas 2 e 3, o Ministério das Cidades não é um ator do processo de implementação do programa. São basicamente os agentes financeiros, as pessoas jurídicas do ramo da construção civil, e as pessoas físicas que desejam adquirir um imóvel. A estrutura de funcionamento é a mesma da faixa 1: o agente gestor pode habilitar novos

\footnotetext{
5 Recentemente, o Banco do Brasil (BB) foi habilitado pelo agente operador (a CEF), e assim passou a participar da implementação do PMCMV, contratando empreendimentos habitacionais destinados para o público alvo do programa. Porém, comparada com as contratações de empreendimentos pela CEF (agente financeira), aquele banco tem uma pequena participação no PMCMV: na fase dois do programa, a Caixa contratou 552.613 unidades habitacionais (UH) para a faixa 1 , contra 105.878 do $\mathrm{BB}$; no montante total, o primeiro contratou 1.670.323, contra 198.516 UH do segundo. Esses dados são válidos até o metade de outubro de 2013.
} 
agentes financeiros, sendo que a CEF atua nesses dois papéis, e cabe as empresas erguerem os empreendimentos de acordo com as regras do programa. As famílias procuram as agências da CEF para solicitar o financiamento habitacional, e se estiverem no perfil do subsídio, serão contempladas pelo benefício.

Tabela 9 Unidades contratadas pelo PMCMV - PJ, fases 1 e 2 do programa (Fontes: dados da CEF trabalhados pelo CEM) - até junho de 2014

\begin{tabular}{|l|c|c|c|c|}
\hline \multicolumn{1}{|c|}{ Produto Caixa } & Faixa 1 & Faixa 2 & Faixa 3 & Total Geral \\
\hline Apoio à produção & - & 400.067 & 217.027 & 617.094 \\
\hline Imóvel na planta & - & 183.890 & 38.768 & 222.658 \\
\hline Plano Empresa da Construção Civil & - & 175 & 40 & 215 \\
\hline Infraestrutura & - & 40 & - & 40 \\
\hline FAR Alienação & 1.070 .738 & - & - & 1.070 .738 \\
\hline Imóvel Rural & 129.042 & - & - & 129.042 \\
\hline FDS & 43.191 & - & - & 43.191 \\
\hline Urbanização & 37.269 & - & - & 37.269 \\
\hline Municípios & 30 & - & - & 30 \\
\hline Total Geral & 1.280 .270 & 584.172 & 255.835 & 2.120 .277 \\
\hline
\end{tabular}

O principal produto da faixa 1 é o FAR $(83 \%$, contra $3 \%$ do FDS e $10 \%$ do imóvel rural), enquanto na faixa 2 e 3 é o apoio à produção (com $68 \%$ contra $31 \%$ do imóvel na planta, na faixa 2, e $84 \%$ contra $15 \%$, na faixa 3). O Plano Empresa da Construção Civil (PECC) e Infraestrutura não representam nem $1 \%$ da produção total da faixa 2, e o mesmo vale para faixa 3. Por fim, a faixa 1 representa a maior quantidade de unidades contratadas pelo programa: $60 \%$ na faixa $1,27 \%$ na faixa 2 e $12 \%$ na faixa 3 . Como há uma preponderância do FAR, Apoio à produção, e Imóvel na planta, esta dissertação focará esses três programas com mais detalhes no que diz respeito às regras do programa, bem como a produção habitacional na Região Metropolitana de São Paulo.

\subsection{O déficit habitacional no Brasil}


O índice do déficit habitacional é produzido pela Fundação João Pinheiro (FJP), e estão disponíveis no site da instituição os relatórios desde o ano de 2000, sendo possível construir uma série histórica com valores do índice para os anos de 2000 e de 2005 até 2012. O estudo feito pela FJP não trata apenas do déficit, mas também da inadequação de moradias, conceito que não foi utilizado na formulação do PMCMV. É o índice do déficit habitacional que determina a distribuição dos recursos financeiros entre os entes da federação: “art. $5^{\circ}$. os recursos do PNHU serão distribuídos entre as unidades da federação, de acordo com a estimativa do déficit habitacional [...] referentes ao ano de 2007 e suas atualizações" (BRASIL, Decreto 6962).

O conceito do déficit habitacional está ligado a uma ideia de necessidades habitacionais, e sua definição é a mesma para toda a série histórica: “indica a necessidade de construção de novas moradias para atender à demanda habitacional da população em um dado momento" (BRASIL, 2011, p. 9). Essa dimensão do estudo analisa a quantidade do estoque habitacional, ao passo que a ideia de inadequação de moradias está atrelada à qualidade de vida dos moradores, ou seja, a qualidade das habitações. É possível subdividir o conceito de déficit em dois: o déficit por reposição de estoque representa as moradias "sem condições de serem habitadas em razão da precariedade das construções ou do desgaste da estrutura física" (BRASIL, 2011, p. 18). Essas são casas que já estão habitadas por uma família que necessita de outro local de habitação devido à insalubridade do local e às condições precárias da habitação.

O déficit por incremento de estoque representa a quantidade de moradias nas quais mais de uma família reside, mas que cada uma poderia constituir um novo lar, caso conseguisse arcar com os custos do aluguel ou da compra de um imóvel. Além disso, as famílias que ganham até 3 salários mínimos, mas que comprometem $30 \%$ da renda mensal com aluguel compõe essa parcela do déficit: 
a necessidade de incremento do estoque, em função da coabitação familiar forçada (famílias que pretendem constituir um domicilio unifamiliar), dos moradores de baixa renda com dificuldade de pagar aluguel e dos que vivem em casas e apartamentos alugados com grande densidade. (BRASIL, 2011, p. $18)$.

A tabela a seguir resume as ideias centrais do déficit habitacional:

Tabela 10 Componentes centrais do conceito do déficit habitacional (Fonte: Estudo do déficit de 2008, FJP).

\begin{tabular}{|c|c|}
\hline Conceito & Variáveis que abrange \\
\hline \multirow{3}{*}{$\begin{array}{l}\text { Déficit por } \\
\text { reposição de } \\
\text { estoque }\end{array}$} & a) Habitações precárias \\
\hline & $\begin{array}{l}\text { Domicílios rústicos (semparedes de } \\
\text { alvenaria, ou madeira aparelhada) }\end{array}$ \\
\hline & $\begin{array}{l}\text { Domícílios improvisados (cuja finalidade é } \\
\text { outra que não a habitação) }\end{array}$ \\
\hline \multirow{5}{*}{$\begin{array}{l}\text { Déficit por } \\
\text { incremento do } \\
\text { estoque }\end{array}$} & b) Coabitação familiar \\
\hline & Cômodos alugados, cedidos, e próprios \\
\hline & $\begin{array}{l}\text { Famílias conviventes secundárias com } \\
\text { intenção de constituir domicílio exclusivo }\end{array}$ \\
\hline & $\begin{array}{c}\text { c) Ônus excessivo com aluguel (famílias que } \\
\text { ganham até } 3 \text { SM, e que gastam } 30 \% \text { ou mais } \\
\text { dessa renda com aluguel) }\end{array}$ \\
\hline & $\begin{array}{l}\text { d) Adensamento excessivo de moradores em } \\
\text { domicílios alugado }\end{array}$ \\
\hline
\end{tabular}

Do ponto de vista conceitual, não há mudanças nos diferentes estudos, mas quando o conceito é operacionalizado existe uma diferença que deve ser destacada: os estudos de 2000 e 2010 foram calculados a partir da amostra do universo do Censo, e os outros estudos foram realizados com os dados da amostra da Pesquisa Nacional por Amostra de Domicílios (PNAD). O primeiro desdobramento disso é que com os dados da PNDA é possível representar a realidade das unidades da federação, em 9 regiões metropolitanas, ao passo que os dados do Censo são possíveis chegar até os municípios. Portanto, os estudos do déficit de 2000 e 2010 são mais precisos, pois utilizam dados do universo, cuja menor unidade de análise é o setor censitário que possui em torno de 250 a 350 domicílios. Além disso, existem diferenças de algumas variáveis usadas para operacionalizar os diversos componentes do déficit, já que o questionário do Censo não é o mesmo do da PNAD. 
Outra ressalva metodológica importante é a "reponderação dos microdados da amostra da Pnad, decorrente dos resultados obtidos pela Contagem Populacional efetuada pelo IBGE em 2007” (BRASIL, 2011, p. 25). Isso modificou o peso da amostra, fato que causa alterações nos resultados do estudo do déficit para os anos de 2005, 2006, 2007. Por isso, no estudo original do déficit do ano de 2007 o déficit total do Brasil era de 6.272.645, mas com a reponderação realizada a partir do estudo de 2008, esse valor caiu para 5.989.064. Para construir a série histórica, esta dissertação adota o seguinte critério: para o ano de 2000, utiliza-se os valores do déficit sem a reponderação, pois os dados são do universo do Censo, e para os anos 2005, 2006, 2007, utiliza-se os dados reponderados. Esses dados são comparáveis com os anos de 2009, 2011 e 2012, pois em todos esses anos o estudo foi gerado a partir da PNAD, ao passo que o estudo de 2000 é passível de comparação com o de 2010, porque os dois foram construídos com os dados do Censo.

Tabela 11 Principais diferenças nas metodologias dos estudos do déficit (Fonte: FUNDAÇÃO JOÃO PINHEIRO, 2013, p. 77)

\begin{tabular}{|c|l|}
\hline Estudo do déficit & \multicolumn{1}{c|}{ Principais mudanças realizadas } \\
\hline \multirow{2}{*}{ DH 2000 } & $\begin{array}{l}\text { 1. Não há informações no questionário Censo sobre } \\
\text { material predominante nas paredes externas. Por is so, } \\
\text { domicílio rústico é calculado indiretamente }\end{array}$ \\
\cline { 2 - 2 } 2. Estima-se diretamente famílias conviventes \\
\hline \multirow{2}{*}{ DH 2007 2008} & $\begin{array}{l}\text { 1. A PNAD passou a perguntas se os membros da família } \\
\text { conviventes desejam ou não constituir um domicílio }\end{array}$ \\
\hline \multirow{2}{*}{ DH 2010 } & $\begin{array}{l}\text { 1. Reponderação dos anos de 2000, 2005, 2006, 2007, } \\
\text { levanto em conta uma estimativa das famílias conviventes } \\
\text { que desejam constituir um domicílio }\end{array}$ \\
\hline $\begin{array}{l}\text { 1. Não há informação sobre famílias conviventes, por isso } \\
\text { a variável foi estimada com um um algoritmo, e um fator } \\
\text { redutor foi gerado para captar exclusivamente aquelas } \\
\text { famílias que desejam constituir um domicílio }\end{array}$ \\
\hline
\end{tabular}

Por fim, o último ponto a destacar com relação a uma análise da série histórica do déficit diz respeito à proporção que o ônus excessivo com aluguel ocupa no resultado final do índice do déficit habitacional. O PMCMV visa reduzir o déficit habitacional do país, mas esse objetivo não é alcançado na proporção do déficit ocupada pelo ônus excessivo com aluguel, 
porque é o mercado que determina o preço dos aluguéis, ou seja, o governo federal não pode regulamentar isso. De fato, o PMCMV pode contribuir para o aumento das famílias que, ganhando até $3 \mathrm{SM}$, comprometem $30 \%$ da renda mensal com aluguel, porque o Minha casa ao injetar recursos no setor da construção civil, gera, como consequência, aumento dos preços e especulação imobiliária: por exemplo, o preço pago em 2009 por um terreno para um empreendimento feito pelo PMCMV não é o mesmo pago em 2011, ou 2012. Além disso, as áreas que recebem empreendimentos do PMCMV tendem a se valorizarem, fato que impacta no preço do aluguel das famílias que moram nessa região. Por isso, se os dados do déficit de 2007 forem comparados com os de 2012 (ambos oriundos da PNAD), nota-se que o ônus excessivo com aluguel aumentou em 537.148 unidades - com efeito, foi o único componente do déficit que sofreu aumento.

Com essas considerações em mente é possível apresentar o gráfico da evolução do total do déficit habitacional no Brasil:

Gráfico 4 Evolução histórica do déficit habitacional total no Brasil - em milhões (Fontes: estudos do Déficit habitacional para os anos de 2000, 2008, 2009, 2010, 2011 e 2012)

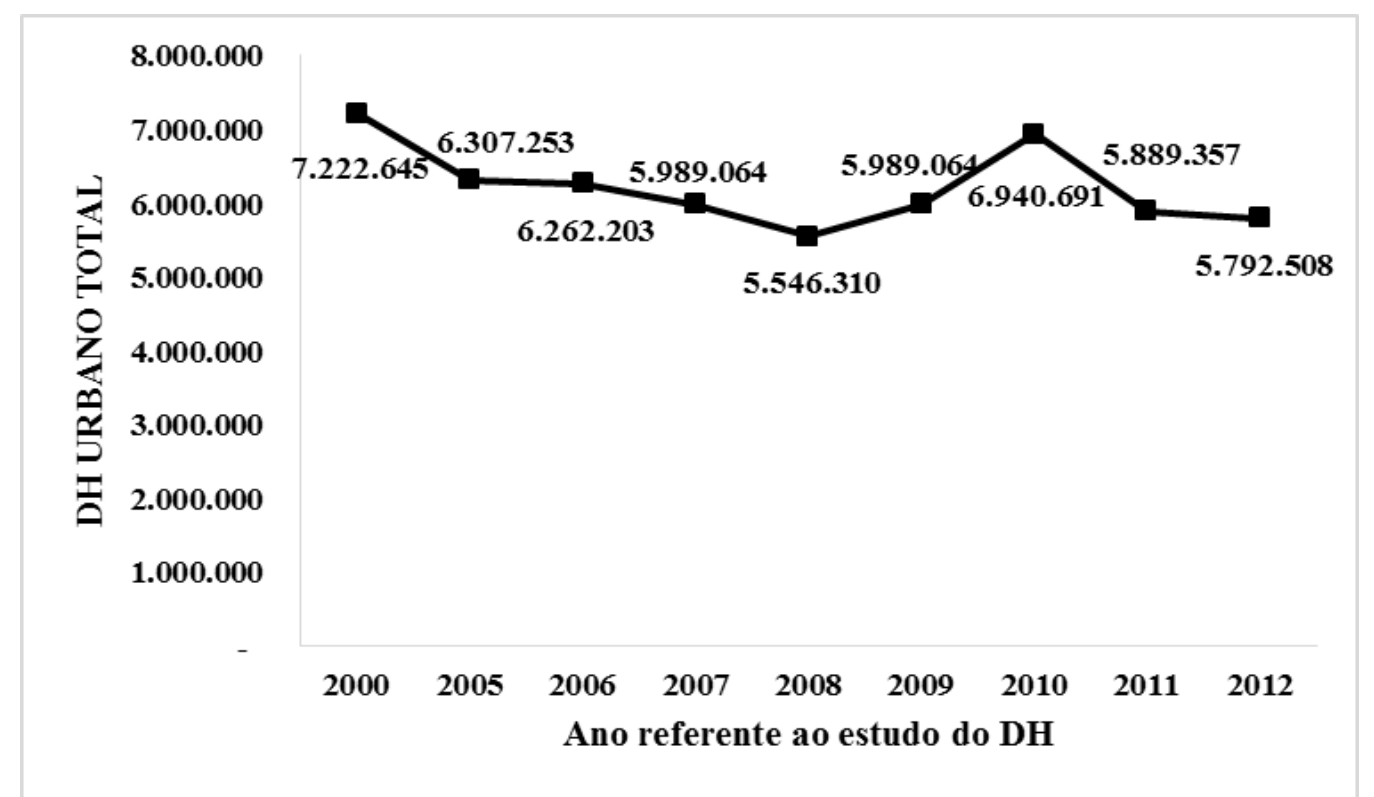

O gráfico sugere uma pouca tendência de declínio do déficit ao longo da década de 2000, e a comparação do déficit de 2000 com o de 2010 aponta a mesma análise, comparação 
mais segura porque ambos são construídos com a amostra do Censo. Estudar a evolução do déficit, comparando esses resultados que foram gerados com alterações na metodologia pode prejudicar a precisão da análise, por isso o déficit deve ser usado como uma referência de um determinado momento histórico. Esta dissertação adotará os dados de 2010, por serem os mais recentes, e por estarem disponíveis para os municípios da Região Metropolitana de São Paulo.

\subsection{A produção habitacional do PMCMV}

A nível nacional, até junho de 2014, foram contratadas 2.120 .362 unidades habitacionais pelo PMCMV na sua parte destinada a pessoas jurídicas, enquanto na parte de pessoa física foram 219.158 unidades. Na parte PJ do programa, as médias de UH por empreendimentos são as seguintes: na faixa 1, é 137 , na faixa 2,114 , e na faixa 3,147 . Notase que a faixa 3 possui uma média maior que a faixa 1, mas esta possui os maiores valores máximos: o empreendimento com mais unidades está localizado em Manaus, e possui 4.988 UH; na faixa 2 esse valor é 1.145 de um empreendimento também em Manaus; e para faixa 3

o maior empreendimento possui $840 \mathrm{UH}$, localizado em Guarulhos (Edifício Único Guarulhos).

Nacionalmente, o PMCMV priorizou desde o começo a construção de unidades para a faixa 1, exceto no ano de 2011, quando a construção de unidades para a faixa 2 foi um pouco superior do que para a faixa 1. Isso é demonstrado com o gráfico que representa a evolução por ano das unidades contratadas pelo programa: 
Gráfico 5 Evolução das unidades contratas pelo PMCMV por ano e por faixas (Fontes: dados da CEF trabalhados pelo CEM)

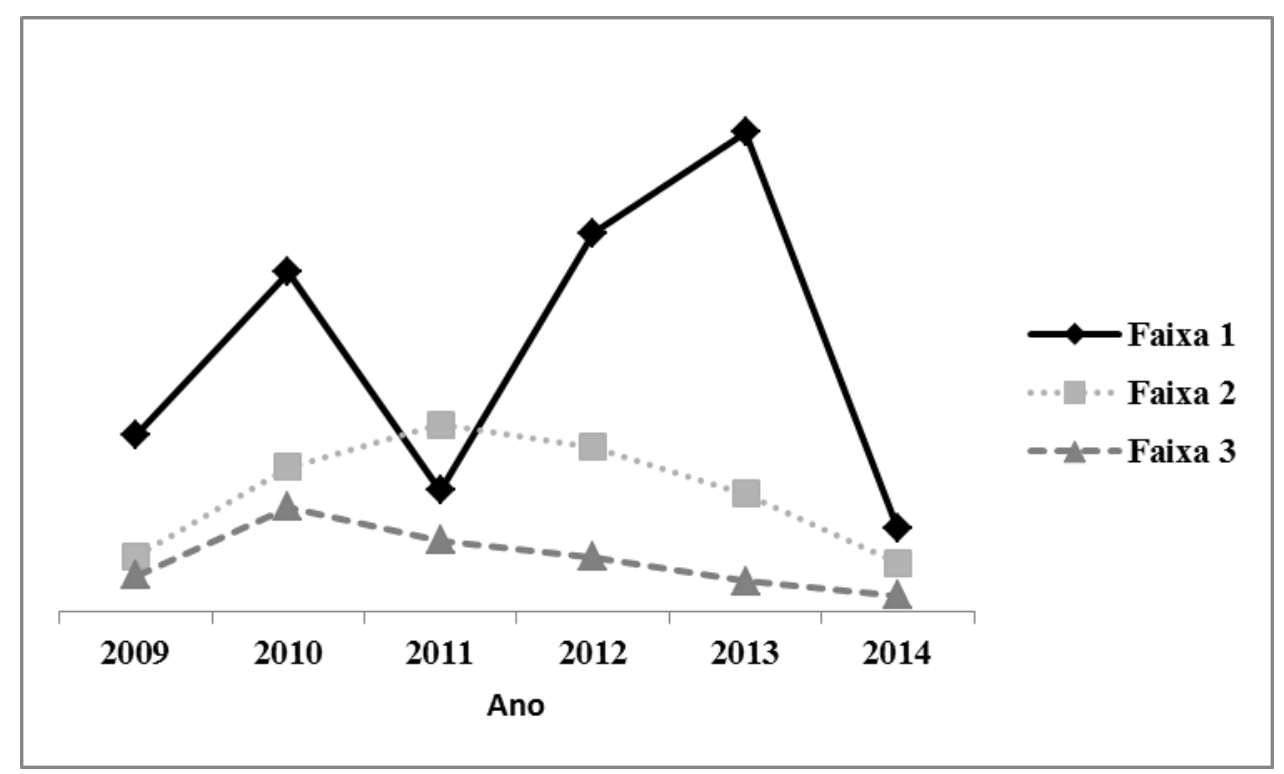

É possível visualizar mais duas informações: a partir de 2011, surge um padrão decrescente de contratação de unidades para a faixa 2 e 3, ao mesmo tempo em que se inicia um padrão ascendente na faixa 1, o qual não foi mantido no ano de 2014. Isto ocorreu provavelmente, porque ainda não se encerrou o ano, e por causa das eleições presidenciais. De todo modo, é possível afirmar que nacionalmente o PMCMV priorizou o atendimento do déficit na faixa 1, afirmação que será demonstrada em seguida com o gráfico da proporção do déficit atendido por estado.

Essas informações tornam o diagnóstico feito pelos analistas, quando o programa foi lançando, menos crítico. Arantes e Fix (2009) afirmaram que possivelmente a tendência de não atingir às classes que realmente precisam do subsídio deveria prevalecer, e Bonduki (2009) foi mais enfático: afirmou ser evidente o risco do programa produzir moradias precárias com pouca aderência ao perfil do déficit habitacional, cuja concentração se encontra na faixa salarial de até $3 \mathrm{SM}$. Com efeito, o autor afirmou que se a meta do programa de construir 400 mil unidades habitacionais para tal faixa for alcançada, "apenas $6 \%$ do déficit deverá ser atendido" (BONDUKI, 2009, p. 14). Nascimento e Tostes (2011) formularam 
argumento similar: o déficit habitacional na faixa de até 3 salários mínimos "pode ser reduzido pelo PMCMV em 7,13\%, enquanto que na faixa de 3 a $10 \mathrm{SM}$ o déficit seria reduzido em 99,63\%".

Os dados apresentados até aqui demonstram que a faixa 1 foi priorizada, sendo que $60 \%$ do total da produção do programa se destinou justamente para as famílias com menor renda. Além disso, enquanto a produção das faixas 2 e 3 descarecia ao longo dos anos, a da faixa 1 crescia. Portanto, é possível afirmar que a faixa 1 foi atingida pelo programa, mas resta saber em qual proporção, e qual a qualidade desse atendimento ${ }^{6}$. Além disso, em 6 estados do país está concentrado $54 \%$ das unidades contratadas para a faixa 1: São Paulo (13\%), Bahia (11\%), Minas Gerais (8\%), Maranhão (7\%), Rio de Janeiro (7\%) e Pará (6\%), ou seja, três localizados no sudeste, e os outros três no nordeste. Essa distribuição está de acordo com o déficit habitacional urbano de 2010 na faixa 1: São Paulo possui 22\%, Rio de Janeiro 8\%, Minas Gerais, 8\%, Bahia 7\%, Pernambuco 4\%, Maranhão 45\%. Com exceção de Pernambuco, e da ordem em que os estados aparecem, pode-se afirmar que os 6 maiores estados que concentram $57 \%$ do déficit habitacional urbano nacional (na faixa 1) foram os mesmos 6 estados que mais receberam unidade na faixa 1.

\footnotetext{
6 Uma análise sobre a qualidade do atendimento do PMCMV deve levar em conta a localização dos empreendimentos, bem como a disponibilidade de infraestrutura urbana e bens e serviços públicos. Produzir essa análise a nível nacional requer um extenso estudo incompatível com os propósitos dessa dissertação, que fará essa análise apenas para a Região Metropolitana de São Paulo.
} 
Tabela 12 Distribuição das UH por estado, e faixas, organizada pela faixa 1 do maior para menor (Fonte: dados da CEF trabalhados a partir do CEM)

\begin{tabular}{|c|c|c|c|c|}
\hline UF & Faixa 1 & Faixa 2 & Faixa 3 & Total Gera \\
\hline SP & 169.348 & 152.798 & 85.397 & 407.543 \\
\hline $\mathrm{BA}$ & 150.310 & 25.493 & 15.825 & 191.628 \\
\hline MG & 111.128 & 70.921 & 13.180 & 195.229 \\
\hline MA & 92.837 & 17.229 & 1.904 & 111.970 \\
\hline $\mathrm{RJ}$ & 91.086 & 29.285 & 30.064 & 150.435 \\
\hline PA & 83.263 & 10.634 & 8.560 & 102.457 \\
\hline $\mathrm{RS}$ & 67.005 & 48.738 & 16.339 & 132.082 \\
\hline $\mathrm{PE}$ & 59.000 & 20.249 & 3.840 & 83.089 \\
\hline PR & 53.247 & 39.886 & 12.723 & 105.856 \\
\hline $\mathrm{AL}$ & 47.473 & 24.462 & 5.016 & 76.951 \\
\hline GO & 46.760 & 20.536 & 11.824 & 79.120 \\
\hline PI & 37.915 & 5.657 & 2.897 & 46.469 \\
\hline MT & 35.285 & 14.664 & 6.630 & 56.579 \\
\hline $\mathrm{CE}$ & 33.359 & 6.307 & 1.612 & 41.278 \\
\hline $\mathrm{SC}$ & 29.217 & 34.130 & 7.598 & 70.945 \\
\hline $\mathrm{AM}$ & 25.245 & 7.716 & 5.885 & 38.846 \\
\hline MS & 23.080 & 9.609 & 3.015 & 35.704 \\
\hline $\mathrm{RN}$ & 22.261 & 8.949 & 3.158 & 34.368 \\
\hline $\mathrm{RO}$ & 15.831 & 2.360 & 2.264 & 20.455 \\
\hline ES & 15.599 & 7.523 & 6.398 & 29.520 \\
\hline $\mathrm{PB}$ & 15.211 & 3.604 & 624 & 19.439 \\
\hline SE & 14.814 & 13.550 & 4.653 & 33.017 \\
\hline TO & 12.978 & 1.328 & 826 & 15.132 \\
\hline $\mathrm{RR}$ & 7.770 & 32 & - & 7.802 \\
\hline AP & 7.653 & - & 364 & 8.017 \\
\hline $\mathrm{DF}$ & 6.335 & 7.464 & 4.807 & 18.606 \\
\hline $\mathrm{AC}$ & 6.260 & 1.048 & 432 & 7.740 \\
\hline Total Geral & 1.280 .270 & 584.172 & 255.835 & 2.120 .277 \\
\hline
\end{tabular}

Com relação ao atendimento do déficit urbano na faixa 1, é importante ter em mente que comparado com o da faixa 2 e 3 , em todos os estados o índice é alto (ocupada mais de 50\%), variando do mínimo que é 50\% (15.900) para Amapá, e 73\% (164.540) para o Maranhão. Os seis estados cujo déficit urbano na faixa 1 é o maior são: Maranhão (73\%), Alagoas (72\%), Paraíba (70\%), Pernambuco (70\%), Ceará (70\%), Bahia (69\%). Desses, o único estado que o ocupa a lista dos cinco que mais receberam unidades da faixa 1 é Maranhão. Existem, portanto, duas maneiras de analisar o déficit habitacional urbano, que revelam duas dimensões da realidade: quando se compara o déficit habitacional entre os 
estados, e quando, no interior de cada estado, se compara a distribuição do déficit nas faixas de renda.

No primeiro caso (comparando os estados, tendo como base a faixa 1), a lista dos 6 estados com maior déficit urbano é: São Paulo (831.872), Rio de Janeiro (330.338), Minas Gerais (325.994), Bahia (269.997), Pernambuco (184.239), e Maranhão (164.540). Nota-se que a diferença entre os números de São Paulo e os outros estados é grande: o déficit urbano na faixa 1 em São Paulo é mais que o dobro do segundo colocado, Rio de Janeiro. No segundo caso (comparando dentro de cada estado, a distribuição do déficit nas faixas de renda), a lista dos 6 estados com maior déficit urbano na faixa 1 é: Maranhão (164.540), Alagoas (72.305), Paraíba (70.801), Pernambuco (184.239), Ceará (153.713), Bahia (269.997). A diferença desses dois modos de análise não é apenas se o total está na coluna (faixas salariais do déficit), ou na linha (déficit urbano por estado), pois revelam dimensões distintas de análise.

No caso em que Maranhão inicia a lista, nota-se que conforme a proporção do déficit na faixa 1 decresce, há um acréscimo nas faixas 2 e 3 do índice, o que significa dizer que há estados nos quais existe uma concentração excessiva do déficit na faixa 1, ao passo que, em outros, o déficit está mais distribuído entre as faixas. É por isso que Maranhão possui proporcionalmente o maior déficit na faixa 1 (73\%), mas em números absolutos é menor que Pernambuco (terceiro na lista em termos proporcionais), ou seja, em Maranhão, o déficit é mais concentrado na faixa 1 do que em Pernambuco. Quando se compara os estados, nota-se que aqueles que possuem maior déficit urbano são os mesmos que possuem altos índices na faixa 1, e que São Paulo concentra $25 \%$ do déficit total. Considerando famílias sem rendimento e faixa, $40 \%$ do déficit está no estado de São Paulo. 
Tabela 13 Distribuição do déficit habitacional urbano por estado e por faixa salarial (Fonte: Estudo do déficit habitacional 2010, Fundação João Pinheiro) - em \%

\begin{tabular}{|c|c|c|c|c|c|}
\hline UF & $\begin{array}{c}\text { Déficit Habitacional } \\
\text { Urbano total }\end{array}$ & $\begin{array}{c}\text { Sem } \\
\text { rendimento }\end{array}$ & Faixa 1 & Faixa 2 & Faixa 3 \\
\hline SP & 25 & 18 & 23 & 27 & 33 \\
\hline RJ & 9 & 8 & 9 & 8 & 8 \\
\hline MG & 9 & 4 & 9 & 9 & 9 \\
\hline BA & 7 & 7 & 7 & 6 & 4 \\
\hline PE & 4 & 7 & 5 & 4 & 3 \\
\hline MA & 4 & 5 & 4 & 3 & 2 \\
\hline RS & 5 & 3 & 4 & 5 & 5 \\
\hline PA & 4 & 7 & 4 & 5 & 4 \\
\hline PR & 4 & 3 & 4 & 4 & 5 \\
\hline CE & 4 & 5 & 4 & 3 & 2 \\
\hline GO & 4 & 5 & 4 & 4 & 3 \\
\hline SC & 3 & 1 & 2 & 3 & 4 \\
\hline AM & 3 & 4 & 2 & 3 & 3 \\
\hline DF & 2 & 1 & 2 & 2 & 2 \\
\hline AL & 2 & 3 & 2 & 1 & 1 \\
\hline PR & 2 & 2 & 2 & 2 & 1 \\
\hline ES & 2 & 1 & 2 & 1 & 1 \\
\hline RN & 2 & 2 & 2 & 2 & 1 \\
\hline MT & 2 & 3 & 2 & 2 & 2 \\
\hline PI & 1 & 2 & 1 & 1 & 1 \\
\hline MS & 1 & 1 & 1 & 1 & 1 \\
\hline SE & 1 & 1 & 1 & 1 & 1 \\
\hline TO & 1 & 1 & 1 & 1 & 1 \\
\hline RO & 1 & 2 & 1 & 1 & 1 \\
\hline AP & 1 & 1 & 0 & 1 & 1 \\
\hline AC & 0 & 1 & 0 & 0 & 0 \\
\hline RR & 0 & 0 & 0 & 0 & 0 \\
\hline Total & 100 & 100 & 100 & 100 & 100 \\
\hline & & & & & \\
\hline
\end{tabular}

O coeficiente de correlação de Pearson indica a correlação entre duas variáveis e a sua direção, ou seja, é possível afirmar se o aumento em uma unidade na variável x impacta na variável y, e se ascendente ou descendente. Normalmente, quando o coeficiente é maior que 0,70, pode-se afirmar que existe uma correlação forte e significativa. A correlação das unidades da faixa 1 construídas nos estados com o seu respectivo déficit habitacional urbano absoluto é de 0,92 , para faixa 2 é de 0,94 , e para faixa 3, 0,97, ou seja, a construção de unidades habitacionais a nível nacional, pelo PMCMV, respeitou a distribuição do déficit, e não construiu mais unidades para faixa 2 e 3. 
É possível extrair essa mesma conclusão de mais duas maneiras. Uma das dificuldades para analisar a redução do déficit é que, proporcionalmente, o déficit da faixa 1 é muito superior ao das faixas 2 e 3, ou seja, o esforço para reduzir o déficit no primeiro caso deve ser superior do que no segundo caso. O impacto da construção de 100.00 para a faixa 1 não é o mesmo que para a faixa 2 e 3: com exceção de São Paulo, Minas Gerais, Bahia e Rio de Janeiro, 100.000 para faixa 2 e 3 reduziria $100 \%$ o déficit de todos os estados. Além disso, como demonstrado anteriormente, é importante ter em mente qual dimensão do déficit se está analisando. Afirmar que Maranhão possui o maior déficit urbano na faixa 1 (73\%) contra os 57\% do estado de São Paulo, não leva em conta que o estado paulista possui altos índices na faixa 2 e 3, bem como na faixa de famílias sem rendimento. Por fim, o déficit habitacional é um problema social que se altera constantemente, isto é, ele é reduzido e aumentado ao mesmo tempo, e é impossível precisar se o saldo é positivo ou negativo: o déficit de 2010 foi reduzido pelas unidades construídas ao longo dos anos de existência do PMCMV, portanto, os números de 2011 não seriam os mesmos de 2010, e assim sucessivamente.

Com essas observações em mente, são realizadas três análises: subtrai-se do déficit urbano de 2010 as unidades que foram produzidas pelo PMCMV no ano de 2009 e 2010, e o resultado se transforma no déficit de 2011; novamente, subtrai-se esse valor pelas unidades construídas em 2011, e o resultado se transforma no déficit de 2012; e assim sucessivamente. Esse é um cenário hipotético, mas que traz duas informações importantes: 
Gráfico 6 Evolução da redução do déficit habitacional urbano (num cenário hipotético) em termos absolutos, por ano (Fonte: dados da CEF trabalhos pelo CEM)

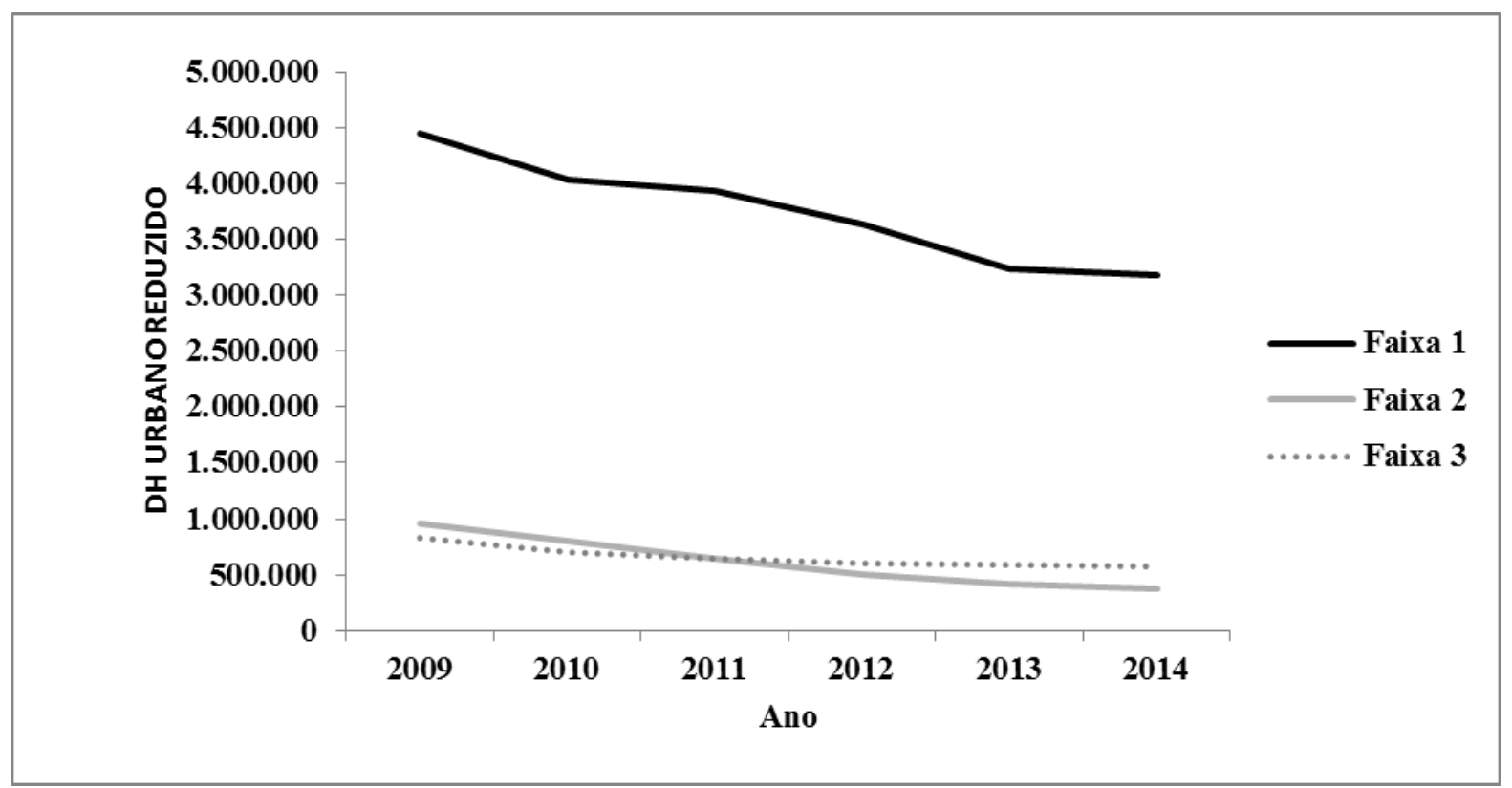

Primeiramente, esse gráfico confirma que o déficit da faixa 1 é muito superior ao das faixas 2 e 3, e isso fica evidente pela distância entre as linhas. Em segundo lugar, a redução do déficit da faixa 1, comparado com o da faixa 2 e 3 foi superior, e se nota isso pela inclinação da linha da faixa 1 , que é muito mais acentuada.

Além disso, foi calculada a correlação das unidades produzidas anualmente por faixa com seu respectivo déficit habitacional, e nesse caso não foi feito o cálculo de subtração para criar os cenários hipotéticos de redução do déficit.

Gráfico 7 Correlação entre o déficit habitacional urbano e a produção habitacional por faixa e por ano (Fonte: dados da CEF trabalhados pelo CEM).

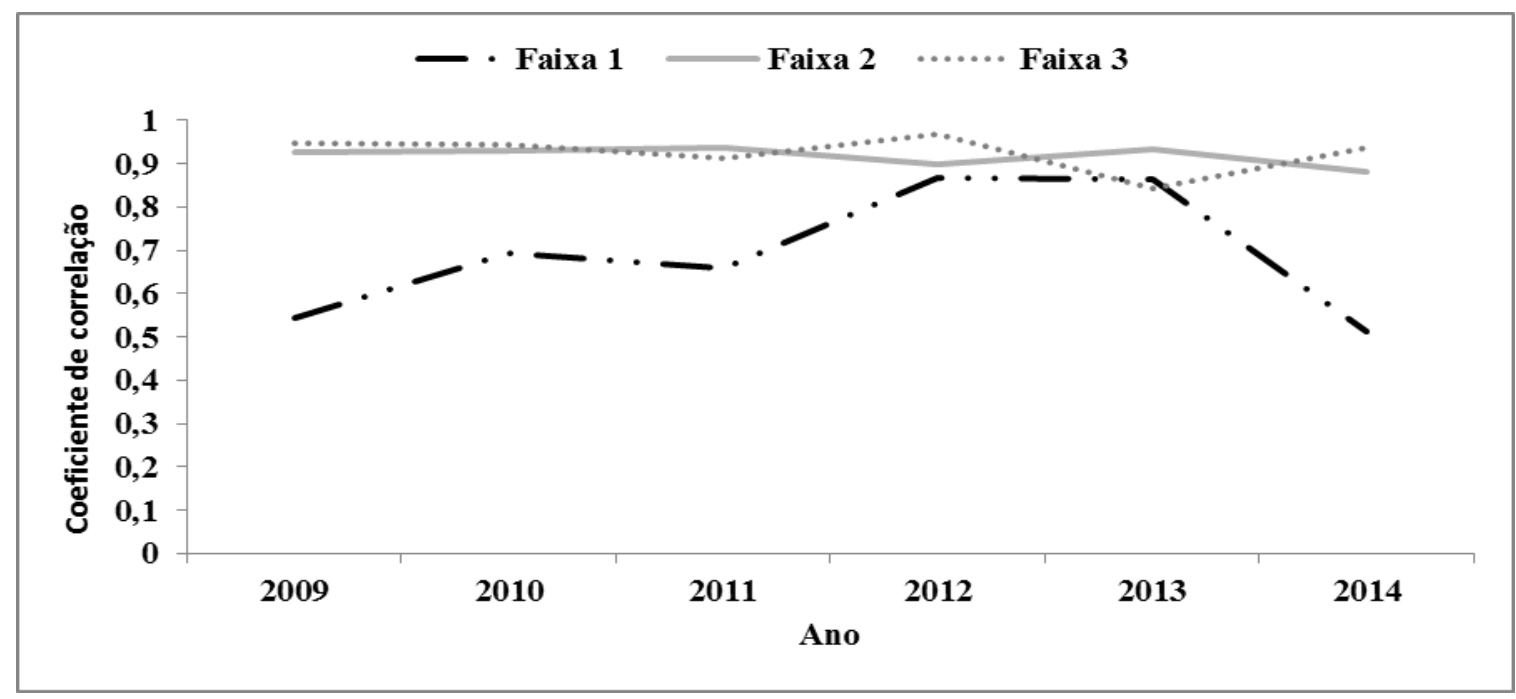


A correlação na faixa 1 aumentou gradualmente e no ano de 2012 e 2013 atingiu os coeficientes mais elevados. Vale lembrar que a correlação da produção total da faixa 1 com o déficit de 2010 é de 0,92 , e se nota a oscilação da relação entre essas duas variáveis desde 2009 até 2014, sendo possível visualizar um ajuste do programa para melhor atender o déficit na faixa 1. Por outro lado, a correlação na faixa 2 e 3 se manteve constante e alta ao longo dos anos.

Por fim, é analisada a proporção da redução do déficit por região geográfica do país, novamente, sem fazer a subtração do déficit para criar os cenários hipotéticos. Foi extraída a proporção do total de unidades contratadas por cada faixa pelo número do déficit urbano de cada faixa. Apenas no norte, a proporção do déficit atendido na faixa 1 foi superior do que nas faixas 2 e 3, exceto para o estado do Amazonas, no qual o déficit atendido na faixa 1 foi de $24 \%$ e nas faixas 2 e 3 , respectivamente, $27 \%$ e $23 \%$ - uma pouca diferença.

Gráfico 8 Proporção do déficit habitacional urbano do norte atendido pelas unidades contratadas até junho de 2014 (Fontes: FJP e CEF, dados trabalhos no CEM).

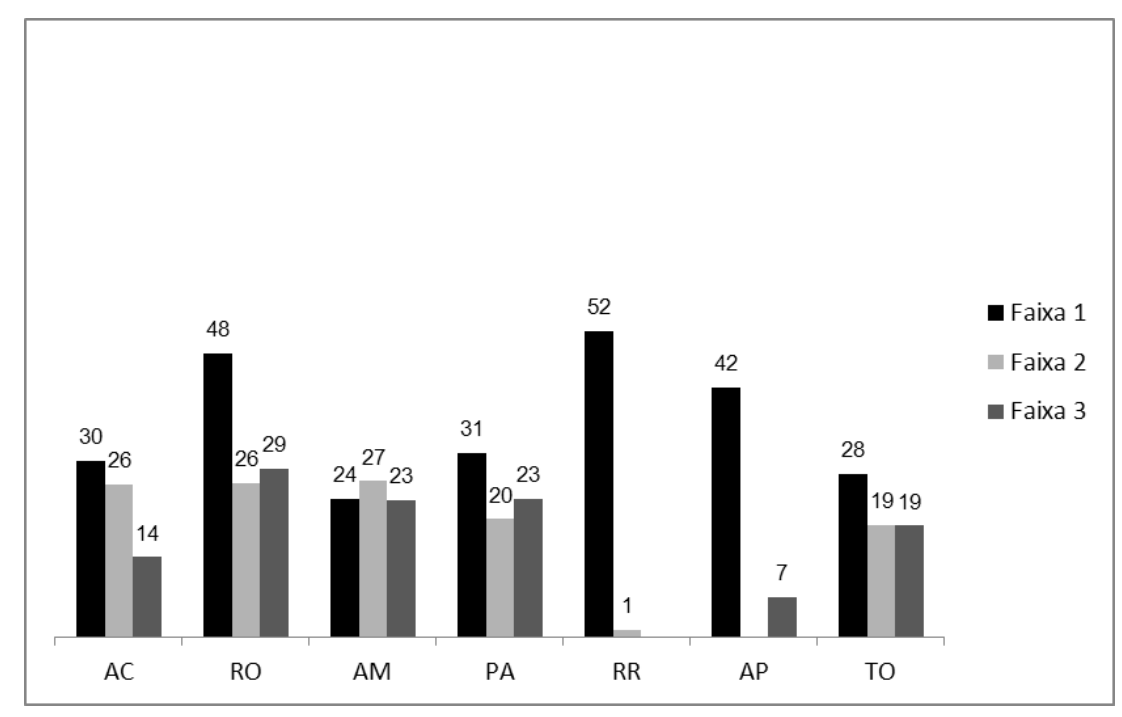


Gráfico 9 Proporção do déficit habitacional urbano do nordeste atendido pelas unidades contratadas até junho de 2014 (Fontes: FJP e CEF).

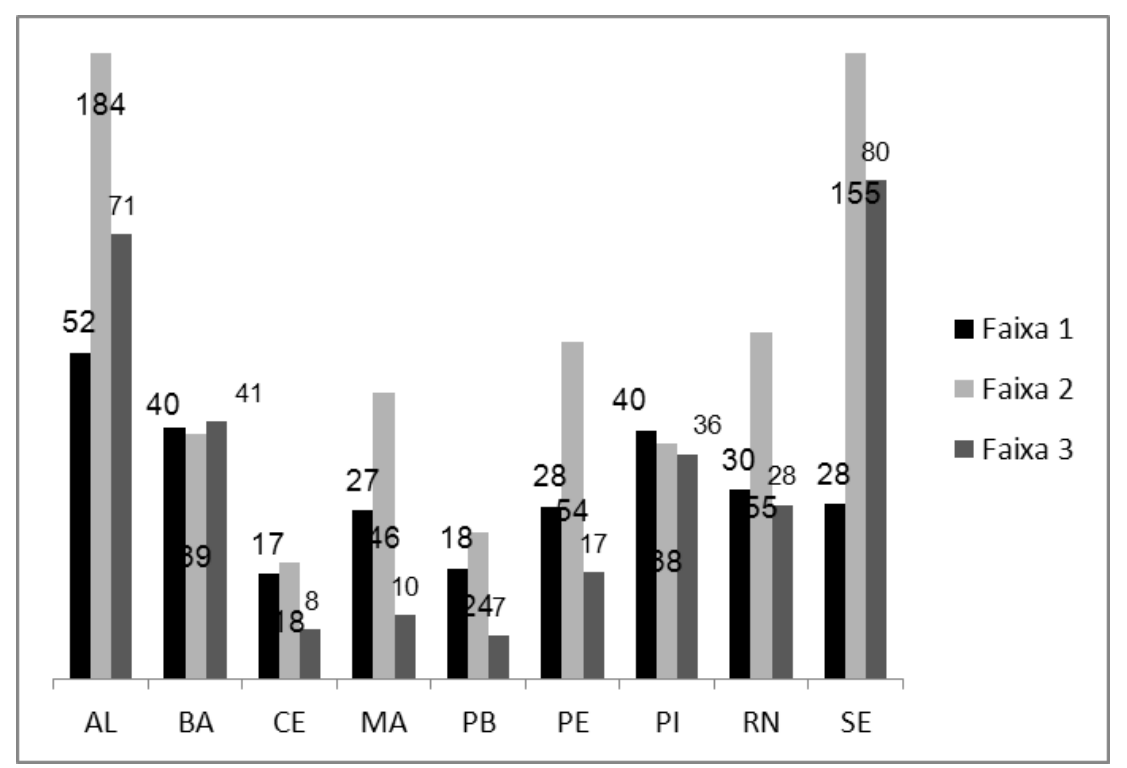

Gráfico 10 Proporção do déficit habitacional urbano do centro-oeste atendido pelas unidades contratadas até junho de 2014 (Fontes: FJP e CEF)

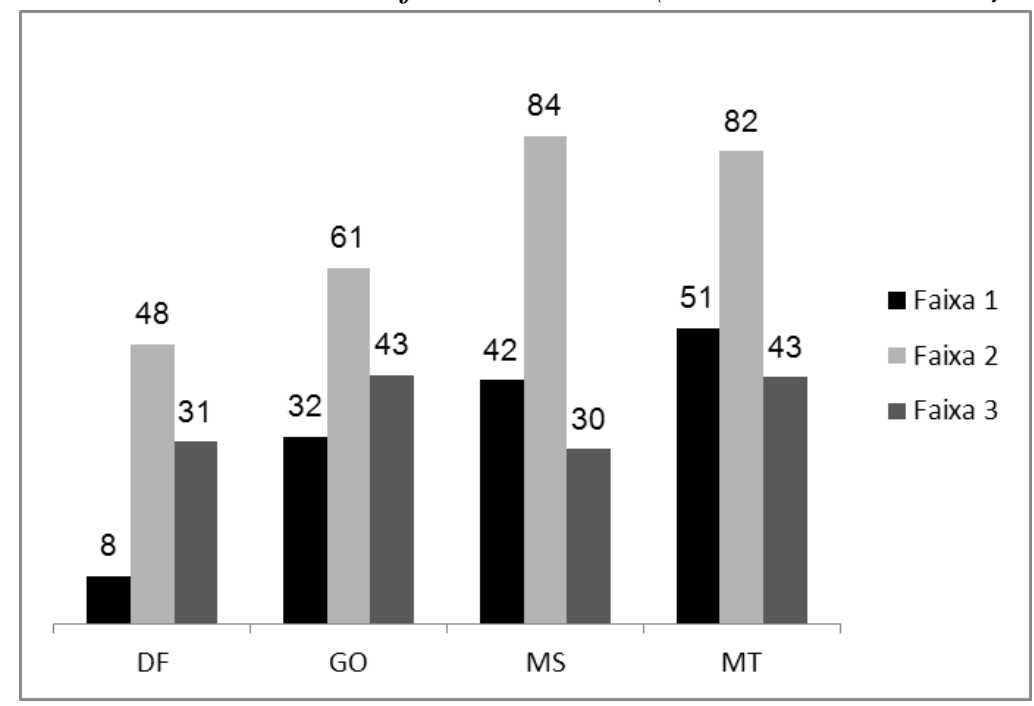

Gráfico 11 Proporção do déficit habitacional urbano do sudeste atendido pelas unidades contratadas até junho de 2014 (Fontes: FJP e CEF)

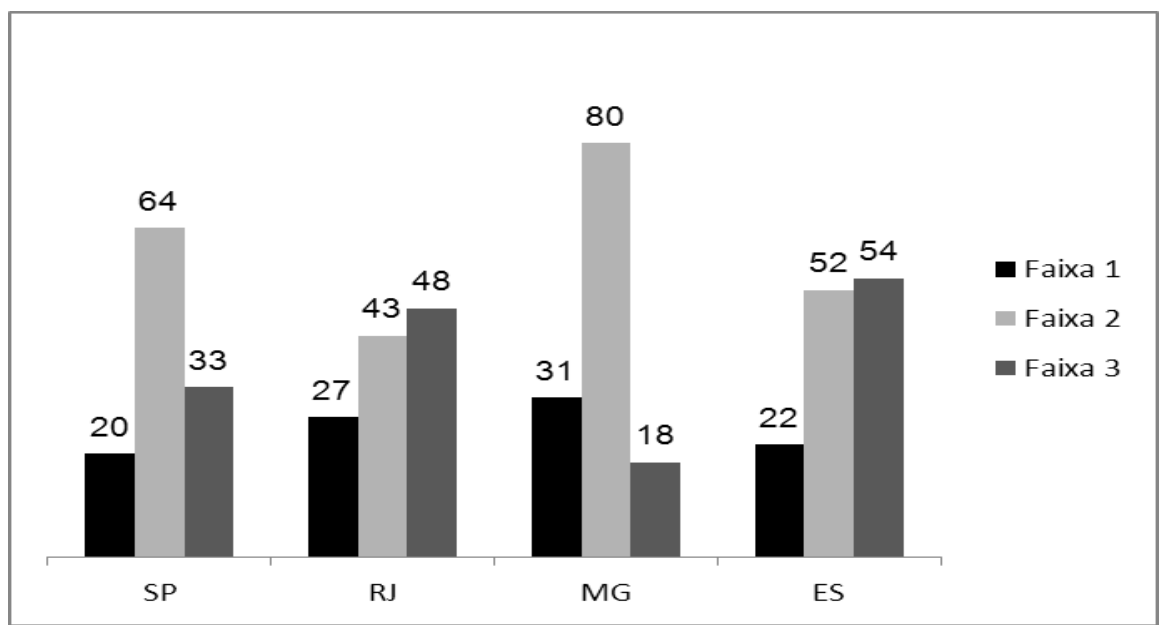


Gráfico 12 Proporção do déficit habitacional urbano do sul atendido pelas unidades contratadas até junho de 2014 (Fontes: FJP e CEF)

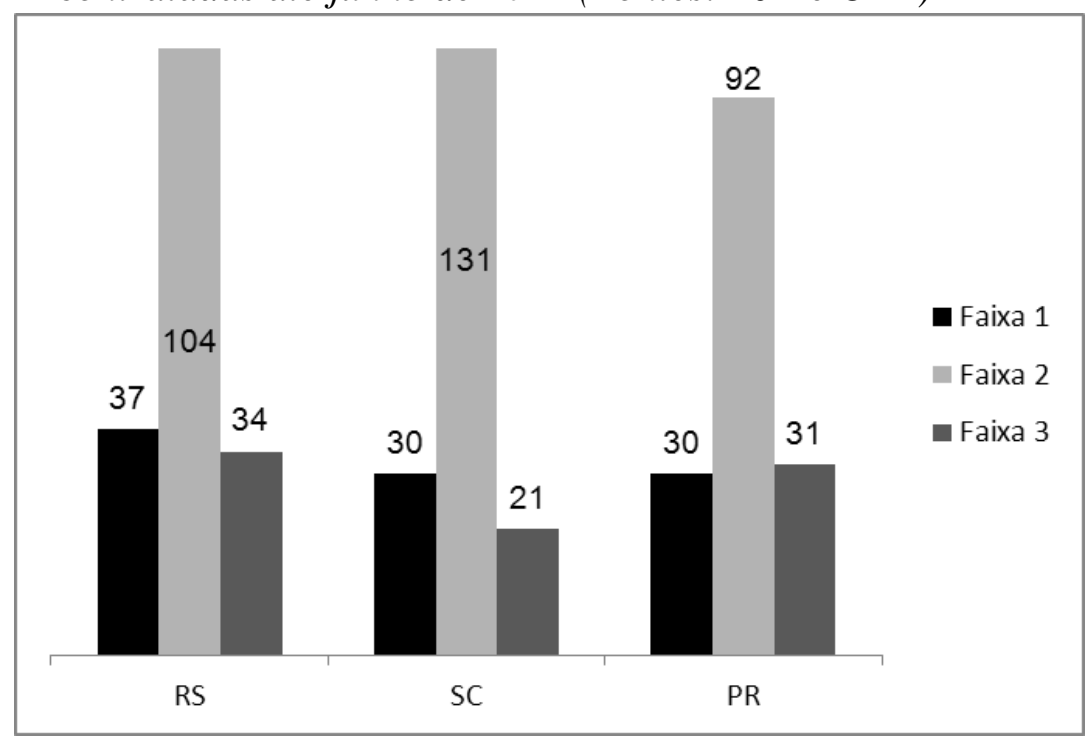

Alagoas, Sergipe, Rio Grande do Sul e Santa Catarina ultrapassaram a quantidade necessária para atender o déficit na faixa 2, e se pode afirmar que nesses estados não foi priorizado o atendimento da faixa 1. Com efeito, os estados que compõe o sul são os que mais atenderam a faixa 2. Roraima e Amapá, por sua vez, são os estados que mais atenderam a faixa 1, quando comparado com o atendimento das faixas 2 e 3 : RR $52 \%$ contra $1 \%$ na faixa 2, e AP $42 \%$ contra $7 \%$ na faixa 3. Por fim, esses gráficos demonstram que não é possível falar em atendimento do déficit habitacional, mas em padrões de atendimento, sendo que cada região teve uma dinâmica diferente. Certamente, se a unidade de análise for reduzida para unidades da federação, ou regiões metropolitanas, a análise ficará mais detalhada, pois o déficit habitacional é um fenômeno social heterogêneo, cujas características diferem-se entre os estados e as regiões - por exemplo, em alguns estados há maior concentração na faixa 1 , em outros o déficit está mais distribuído entre as faixas.

\subsection{Conclusão}


Este capítulo demonstrou que existe uma correlação entre a produção habitacional da faixa 1, 2 e 3 com os respectivos déficits, porém, no início do programa, a correlação era menor na faixa 1, a qual aumentou ao longo dos anos. Além disso, o PMCMV priorizou nacionalmente a produção de habitação para a faixa 1, sendo que $60 \%$ das habitações destinaram-se para essas famílias, $28 \%$ para faixa 2 e $12 \%$ para a faixa 3 . Portanto, a nível nacional, não há um desajuste entre o déficit e a produção habitacional do programa.

Porém, quando o atendimento do déficit em cada estado é analisado, alguns desajustes entre a produção e o déficit aparecem: os estados do norte são aqueles que mais priorizaram o atendimento na faixa 1 . De fato, na média, esses estados reduziram em $36 \%$ o déficit na faixa 1, seguido pelo centro oeste, cujo déficit na faixa 1 foi reduzido em $33 \%$; no sul, a média da redução foi de $32 \%$, no nordeste $31 \%$, e no sudeste $25 \%$. Portanto, a região geográfica onde mais se concentra o déficit na faixa 1 é a que, na média, menos priorizou o atendimento das famílias que ganham até 3 salários mínimos, especificamente, $8 \%$.

Além disso, foi destacado que a análise do atendimento do déficit deve ser relativizada por três razões: primeiro, desde o estudo do déficit habitacional de 2000, a metodologia foi alterada, incluindo uma reponderação dos dados. Isso afetou principalmente os valores para os anos de 2005, 2006, 2007. Em segundo lugar, a proporção do déficit na faixa 1 é muito superior aos da faixa 2 e 3 , fato que transforma o objetivo de reduzir o déficit na faixa 1 mais difícil. Por fim, existem aquelas famílias que pertencem à faixa 1, mas migraram para a faixa 2, e isso faz com que a redução do déficit na faixa 2 seja um pouco inflada, e também existem alguns casos de famílias que adquiriram imóveis nas faixas 2 e 3 apenas para investir e não para constituir um novo lar. 


\section{Capítulo 3 Detalhes do processo de produção de empreendimentos pelo PMCMV}

Este capítulo defende que para entender a política habitacional que o PMCMV representa, é preciso compreender os detalhes das instituições envolvidas no processo de produção das habitações, os atores engajados nesta produção, e as regras do programa. Essa visão é baseada na premissa de que as instituições importam, sobretudo, porque estabelecem um quadro de regras que guia as ações que os diversos atores podem (ou não) assumir. Essas regras são de duas naturezas: o que está escrito nas leis, nos decretos, nas portarias, mas também o que não está escrito e não é proibido pelo quadro legal das regras.

Além dessas premissas, este capítulo defende que qualquer análise do PMCMV deve levar em conta que o programa é constituído por diversos subprogramas, mas é possível dividir a produção habitacional em dois Minha Casa Minha Vida: o PMCMV-Faixa 1, e o PMCMV-faixas 2 e 3. De maneira geral, uma parcela da literatura sobre o MCMV pouco considerou essa diferença nas análises, a qual é essencial para se entender que parte do programa visa à construção de habitação de interesse social (HIS), mas a outra parte destinase à habitação de mercado popular (HMP).

Outras diferenças decorrem da distinção do PMCMV-faixa 1 e PMCMV-faixa 2 e 3: os procedimentos de aprovação do projeto dos empreendimentos na Caixa, a estratégia que as empresas de construção civil adotam para encontrar terra urbana, e o ator que executa o empreendimento - na faixa 1, a empresa de construção civil atua como prestadora de serviço, e nas faixas 2 e 3 como incorporadora. Portanto, ao distinguir o PMCMV-faixa 1 e o PMCMV-faixa 2, e ao considerar suas respectivas regras, atores e instituições envolvidas no processo de produção das habitações que, esta dissertação pretende contribuir para o debate sobre o PMCMV, adicionando uma visão neoinstitucionalista da Ciência Política. 


\subsection{As regras do jogo e o PMCMV}

Na literatura sobre o neoinstitucionalismo, é possível encontrar explicações de cunho histórico, da escolha racional e sociológico (IMMERGUT, 1998; TAYLOR \& HALL, 2003). Isso evidencia divergências internas na escola neoinstitucionalista no que se refere ao método de pesquisa, e apesar disso é possível afirmar que existe uma premissa que permeia toda análise neoinstitucionalista: as instituições importam. A justificativa para tal afirmação pode variar dependendo do/a autor/a, mas esta dissertação endossa a ideia segundo a qual as instituições importam, porque estruturam as interações dos atores num determinado contexto (TAYLOR \& HALL, 2003), ou mais precisamente, “decisões e preferências são artefatos das instituições" (IMMERGUT, 1998, p. 10).

Immergut (1996) analisa o processo de decisão sobre o programa de seguro social de saúde na Suécia, Suíça e França, e conclui defendendo a tese segundo a qual a melhor explicação desses resultados [dos diferentes outcomes nos países que compara] se encontra na análise das instituições políticas de cada país” (IMMERGUT, 1996, p. 2). Skocpol (1985) realiza uma análise sobre as diversas estratégias utilizadas para estudar o Estado, e enfatiza a necessidade de estudá-lo "como ator, ou como estruturas institucionais com efeitos na política" (SKOCPOL, 1985, p. 27, tradução nossa). Ambos os textos possuem objetos de estudos distintos, e foram publicados com a diferença de 9 anos, porém está presente nos dois a tese segundo a qual as instituições são relevantes para explicar determinados contextos e/ou resultados políticos.

Esta dissertação endossa a mesma tese: parte da explicação dos resultados da produção habitacional do PMCMV está presente nas instituições e nos atores engajados na construção das unidades, e não apenas no mercado de terras, no interesse privado das empresas, ou na junção desses dois elementos. Além do Ministério das Cidades, da Caixa (enquanto agente 
operadora e agente financeira), e da prefeitura que são atores e instituições, estas são também as regras do jogo estabelecidas pelos atores que possuem o poder para tanto. As regras do jogo (ou as regras) do PMCMV foram estabelecidas de maneira incremental e se modificaram desde o lançamento do programa.

São diversas medidas provisórias, que foram transformadas em leis, cujos pontos específicos foram regulamentados por decreto-lei. Além disso, existe uma série de portarias do Ministério das Cidades, e deste em conjunto com a Casa Civil, bem como Circulares da Caixa, e instruções normativas. Além de tudo isso, a Caixa formulou manuais de procedimentos aplicáveis às operações do FAR, do Apoio à Produção, e Imóvel na Planta. As regras do jogo são importantes, porque estabelecem como o processo de produção das moradias pode ocorrer, e também estabelecem atribuições claras e específicas para cada ator.

Além disso, no PMCMV-faixa 1, para um município poder utilizar os recursos disponíveis pelo governo federal, é preciso que assine um termo de adesão ao programa, no qual se compromete a pelo menos disponibilizar terrenos em zonas de interesse social (ZEIS), ou transformar as áreas com empreendimentos do PMCMV em ZEIS. Esse termo de adesão também estabelece compromissos por parte do poder público com relação à disponibilidade de infraestrutura urbana, e equipamentos e serviços públicos. Portanto, ao considerar as regras do jogo, concede-se papel ativo ao poder público local na produção das habitações, concessão negada por parte da literatura sobre o PMCMV.

Este capítulo descreve algumas regras do jogo no que diz respeito à aquisição do terreno, ao papel desempenhado pelas empresas que atuam na faixa 1, e nas faixas 2 e 3 (papel este estabelecido em portarias), aos diferentes processos de aprovação dos projetos na Caixa, e explora com mais detalhe a diferença entre faixa 1, e faixas 2 e 3 , bem como a distinção entre imóvel na plana e apoio a produção. 


\subsection{A aquisição do terreno para o empreendimento}

Cabe às empresas procurarem e encontrar uma área na cidade que desejam construir um empreendimento, e que esteja de acordo com a legislação do PMCMV. Nesta etapa, surge a primeira diferença entre as faixas: na busca por terrenos para empreendimentos da faixa 1, as empresas podem priorizar regiões que possuam zonas especiais de interesse social (ZEIS), ou mesmo solicitar para as prefeituras que indiquem quais regiões que o poder público local deseja construir habitação de interesse social (HIS). Porém, de acordo com a Portaria 168 de 2013, para participar do MCMV, o município assina um termo de compromisso junto ao governo federal, no qual se compromete a "apresentar proposta legislativa que disponha sobre os critérios e a forma de reconhecimento do empreendimento a ser construído como de zona especial de interesse social - ZEIS” (BRASIL, 2013b).

Disto decorre que, segundo a legislação, um empreendimento do MCMV para faixa 1 será sempre construído em ZEIS, podendo ocorrer de duas maneiras: o terreno encontrado pela empresa de construção já pertencer a uma ZEI, ou não, e neste caso cabe ao município transformar em ZEI a região (ou apenas o terreno) que a empresa deseja construir as habitações. Outra diferença da faixa 1 para as faixas 2 e 3 diz respeito à operação de aquisição de terreno, que pode ocorrer de três maneiras: na faixa 1: o terreno pode ser de propriedade da construtora, pode ser propriedade de um terceiro (pessoa física), ou pode ser uma doação do poder público local (da prefeitura, por exemplo).

Nos dois primeiros casos ocorre a venda do terreno para o FAR, e no terceiro caso a prefeitura assina um termo de doação do terreno ao FAR, ou seja, o FAR passa a ser o proprietário do terreno no qual será construído um empreendimento para a faixa 1. Isso está de acordo com a atribuição de cada participante do programa: enquanto agente financeira do programa, a CEF deve "adquirir as unidades habitacionais destinadas à alienação, em nome 
do FAR" (BRASIL, 2013b), e cabe às empresas de construção civil "apresentar às instituições financeiras oficiais federais projetos de produção de empreendimentos para alienação dos imóveis", e "executar os projetos contratados pela instituição financeira oficial federal" (BRASIL, 2013b). Portanto, as empresas apenas apresentam os projetos de construção, e o executam, sendo que o custo do terreno está incluso no projeto apresentado, e o/a proprietário/a do terreno será remunerado/a pelo custo do terreno.

Para pagar pelo terreno, a Caixa (agente financeira) faz uma avaliação do preço de mercado e compara com o valor apresentado na proposta (caso o terreno seja da construtora), ou com o valor apresentado na opção ou na promessa de compra e venda estabelecida com a pessoa física. Após essa comparação, a CEF (enquanto agente financeira) escolhe o menor valor e efetua o pagamento. Vale lembrar que, o recurso financeiro integrado ao FAR pelo governo federal, por meio de cotas, diz respeito exclusivamente ao pagamento das despesas relativas às obras do PMCMV, dentre as quais está inclusa a aquisição de terrenos: “os valores máximos de aquisição [...] poderão compreender os custos de aquisição do terreno, edificação, equipamentos de uso comum, tributos, [(...)]” (BRASIL, 2013b). Portanto, quem arca com os custos da compra do terreno é o FAR, e não a empresa de construção civil, que no máximo pode encontrar um terreno e assinar uma opção de compra e venda com o proprietário.

O terreno que receberá o empreendimento, além de pertencer a uma ZEI, deve fazer parte da malha urbana do município, ou estar localizado em zonas de expansão urbanas, previamente definidas pelo plano diretor da cidade. Além disso, deve estar dotado de infraestrutura urbana básica, como energia, água, e esgoto, vias de acesso, coleta do lixo, sarjetas, entre outras. Empreendimentos (seja individuais ou em conjuntos) que ultrapassem 1000 UH, devem garantir áreas para a implementação de equipamentos públicos para atender a demanda gerada pela construção das moradias. Por fim, existe um limite de construção de 
5.000 unidades no caso de haver um empreendimento contíguo a outro: isso ocorre quando "a menor distância, em linha reta, do ponto do perímetro da sua poligonal mais próximo ao perímetro da poligonal do outro empreendimento for igual ou inferior a 1.000 (um mil) metros" (BRASIL, 2013b).

É importante destacar que foram alteradas essas regras sobre a qualidade do terreno em termos de infraestrutura urbana, e serviços e equipamentos públicos, bem como os casos especiais de empreendimentos que possuem mais de 1.000 unidades, e o valor máximo de unidades construídas em empreendimentos contíguos. A primeira Portaria (Portaria 139 de 2009) era vaga sobre esses quesitos, e afirmava que "deverá ser considerada a existência ou ampliação dos equipamentos e serviços relacionados à educação, saúde e lazer" (BRASIL, 2009a). Não havia também o conceito de empreendimentos contíguos, tampouco a existência de um limite de construção de unidades por empreendimento. Apenas na fase 2 do PMCMV, com a promulgação da Portaria 465 de 2011 (BRASIL, 2011d) inovações foram criadas no processo de produção dos empreendimentos. Por exemplo: “os empreendimentos que totalizem mais de mil unidades, deverão ter garantidas áreas para implantação dos equipamentos públicos necessários para atendimento da demanda gerada por estes” (BRASIL, 2011d). Apenas em 2013 foi estabelecido o conceito de empreendimentos contíguos, mas já em 2011 existia um limite de 300 unidades aos empreendimentos construídos sob a forma de condomínio, valor que poderia ser elevado, caso o agente financeiro aprovasse.

Esses são alguns pontos que a legislação estabelece e que foram alterados ao longo dos anos, e, na prática, é possível a construtora encontrar um terreno que não contenha algum tipo de infraestrutura urbana, ou mesmo equipamento público. Por isso, a Portaria 168 de 2013, do Ministério das Cidades, prevê em seu anexo VI, a contratação de equipamentos de educação e saúde, e outros complementares à habitação. Também a mesma Portaria diz que "as redes e sistemas de saneamento poderão ser doados pelo FAR” (BRASIL, 2013b). Portanto, pelo 
menos do ponto de vista legal, o PMCMV não delegou totalmente à iniciativa privada a escolha dos terrenos para construir empreendimentos para a faixa 1, pois estabeleceu alguns critérios restritivos. Inicialmente, esses critérios eram poucos e vagos, e tornaram-se mais claros e definidos com a evolução do programa, que incluiu a necessidade de equipamentos e serviços públicos. Porém, é possível afirmar que a legislação atual não diz nada sobre o transporte público, ou o acesso à cidade em grandes centros urbanos, pontos essenciais para evitar ou mesmo atenuar a possível segregação urbana gerada pelo programa.

Pode-se dizer então que tais restrições diminuem o universo de terrenos aptos a receber um empreendimento do PMCMV, dificultando a busca por terra urbana, empecilho que é agravado em grandes centros urbanos, como a RMSP (ou outras regiões metropolitanas), pois já existe restrição de terrenos disponíveis para a construção de HIS. Ademais, existe outro obstáculo: encontrar um terreno cujo preço de compra não seja muito elevado para não inviabilizar financeiramente a construção do empreendimento. Isto porque, a Portaria 521 de 2012 (BRASIL, 2012a) estabelece que na RMSP cada UH para a faixa 1 não pode ser comercializada por mais do que 76 mil, valor elevado para 96 mil por meio do Casa paulista, acordo firmado entre o governo de São Paulo e o federal, por meio do qual a Companhia de Desenvolvimento Habitacional e Urbano (CDHU) aporta 20 mil por UH. As empresas de construção civil então precisam encontrar uma área cuja fração de terreno (valor total do terreno dividido pelo número total de UH que se pretende construir) esteja entre 11 a 13 mil, caso contrário o valor da venda da moradia excederá 96 mil.

A informação sobre a fração do terreno foi fornecida na entrevista feita com a equipe técnica da ENCAMP, empresa especializada na construção de empreendimentos para faixa 1, porém, é possível validá-la empiricamente. Dos 178 empreendimentos construídos na RMSP até junho de 2014, 85 foram realizados em terrenos doados pelo poder público local, e o valor médio desses terrenos é de $\mathrm{R} \$ 5.130 .670,00$, e a média de UH desses empreendimentos é 327, 
com esses valores a fração do terreno fica em torno de 15 mil. Como são terrenos doados pelo poder público, na prática as construtoras não tiveram nenhum gasto com a legalização da área, ou com a construção de alguma infraestrutura, e o fato do valor mencionado exceder 2 mil não afeta a viabilidade financeira desses empreendimentos, justamente porque o custo do terreno não entra na conta. A tabela, a seguir, descreve quais foram os municípios que doaram terrenos, a quantidade de UH construídas nesses casos, e a massa total do valor desses terrenos.

Tabela 14 Municípios que doaram terrenos ao PMCMV - FAIXA 1 (Fonte: dados da CEF trabalhados pelo CEM).

\begin{tabular}{|c|c|c|c|}
\hline MUNICÍPIO & VALOR TOTAL DOS TERRENOS & EMPREENDIMENTOS & TOTAL DEUH \\
\hline SÃO PAULO & $\mathrm{R} \$ 94.185 .195,02$ & 25 & 8672 \\
\hline EMBU & $\mathrm{R} \$ 12.236 .014,40$ & 11 & 684 \\
\hline GUARULHOS & $\mathrm{R} \$ 109.969 .575,63$ & 9 & 6286 \\
\hline SUZANO & $\mathrm{R} \$ 31.268 .628,81$ & 7 & 1700 \\
\hline SANTO ANDRÉ & $\mathrm{R} \$ 21.328 .476,38$ & 6 & 1120 \\
\hline CARAPICUÍBA & $\mathrm{R} \$ 16.020 .188,57$ & 3 & 816 \\
\hline DIADEMA & $\mathrm{R} \$ 7.506 .912,70$ & 3 & 466 \\
\hline ITAQUAQUECETUBA & $\mathrm{R} \$ 15.605 .617,46$ & 3 & 888 \\
\hline MAUÁ & $\mathrm{R} \$ 9.808 .020,50$ & 3 & 512 \\
\hline MOGI DAS CRUZES & $\mathrm{R} \$ 27.857 .001,38$ & 3 & 1840 \\
\hline TABOÃO DA SERRA & $\mathrm{R} \$ 10.272 .940,48$ & 3 & 884 \\
\hline COTIA & $\mathrm{R} \$ 5.110 .544,00$ & 1 & 256 \\
\hline EMBU-GUAÇU & $\mathrm{R} \$ 5.496 .437,73$ & 1 & 360 \\
\hline FRANCISCO MORATO & $\mathrm{R} \$ 5.911 .873,17$ & 1 & 300 \\
\hline ITAPECERICA DA SERRA & $\mathrm{R} \$ 19.453 .536,88$ & 1 & 816 \\
\hline ITAPEVI & $\mathrm{R} \$ 3.547 .044,61$ & 1 & 181 \\
\hline MAIRIPORÃ & $\mathrm{R} \$ 22.000 .000,00$ & 1 & 1100 \\
\hline OSASCO & $\mathrm{R} \$ 5.172 .787,41$ & 1 & 300 \\
\hline POÁ & $\mathrm{R} \$ 4.956 .239,36$ & 1 & 256 \\
\hline SÃO BERNARDO DO CAMPO & $\mathrm{R} \$ 8.400 .000,00$ & 1 & 420 \\
\hline TOTAL GERAL & $\mathrm{R} \$ 436.107 .034,49$ & 85 & 27857 \\
\hline
\end{tabular}

Até este ponto, não foi mencionado em momento algum a figura do incorporador na faixa 1, porque a empresa da construção civil que participa do MCMV, construindo moradia para aquela faixa é uma prestadora de serviço. Esta apenas formula os projetos dos empreendimentos, apresenta-os a CEF, e caso aprovado, executa-os. A operação de compra e 
venda do terreno é de competência da CEF (agente financeira) que age em nome do FAR, e, o máximo que a empresa pode fazer é intermediar ou facilitar o processo de compra e venda, indicando os terrenos para a Caixa. Esta, por sua vez, compara o preço oferecido com a análise técnica realizada pelos seus especialistas, e paga o menor valor encontrado. Caso a empresa de construção civil obtenha algum ganho extra na operação de compra e venda, certamente será fruto de alguma ação ilícita, e não de incorporação. Além disso, a comercialização dos empreendimentos da faixa 1 é realizada pela $\mathrm{CEF}$, por meio de contratos de financiamento habitacional, cabendo às prefeituras fazer o cadastramento e o sorteio das famílias aptas a firmarem o contrato com a Caixa.

\subsection{O incorporador e o prestador de serviço}

A afirmação de que na faixa 1 não há incorporador é válida, se for definido tal como está descrito na Lei $n^{\circ} 4.591$, de 16 de dezembro de 1964:

Art. 29. Considera-se incorporador a pessoa física ou jurídica, comerciante ou não, que embora não efetuando a construção, compromisse ou efetive a venda de frações ideais de terreno objetivando a vinculação de tais frações a unidades autônomas, em edificações a serem construídas ou em construção sob regime condominial, ou que meramente aceite propostas para efetivação de tais transações, coordenando e levando a têrmo a incorporação e responsabilizando-se, conforme o caso, pela entrega, a certo prazo, preço e determinadas condições, das obras concluídas (BRASIL, 1964).

Já Ribeiro (1997, p. 93) concebe o incorporador como “o iniciador e organizador do processo de produção da moradia", e inclui como atividades exercidas por esse ator a concepção e estrutura do empreendimento, a análise da situação do mercado, a escolha do terreno e sua valorização, promoção e venda das unidades habitacionais, entre outras funções. A escolha do terreno é essencial para o incorporador, pois parte do seu lucro é oriundo desta operação: ao comprar um terreno e construir um empreendimento, o incorporador transforma 
o uso do solo, alterando o seu valor financeiro, ou seja, "o incorporador [compra] terrenos a um preço determinado pelo uso presente e [vende] o conjunto edificação/terreno a um preço determinado pelo uso transformado" (RIBEIRO, 1997, p. 98).

Esse seria o incorporador, operando no mercado de habitação, mas nada disso ocorre na construção de moradias pelo PMCMV para a faixa 1: as características dos empreendimentos são estabelecidas pelo Ministério das Cidades, e não há necessidade de se fazer uma análise da situação do mercado, pois o que determina a contratação do empreendimento é o déficit habitacional e as regras do programa; o terreno pode ser escolhido pela construtora, ou pode ser de sua posse, mas isso não está atrelado a uma valorização, pois é o FAR quem compra o terreno, escolhendo o menor valor; e, por fim, cabe à CEF vender as UHs, e não à empresa que construiu os empreendimentos para a faixa 1. Portanto, por mais que haja uma transformação do uso do solo pela construção das moradias, pela implementação de infraestrutura urbana e de equipamentos públicos (caso não houvesse anteriormente), a diferença entre o valor pago pelo terreno e o novo valor que assume com a transformação do uso do solo não é destinada à empresa que construiu o empreendimento, ou à Caixa.

Diante dessas considerações, algumas afirmações feitas pelos críticos do PMCMV podem ser consideradas um pouco equivocadas:

as incorporadoras imobiliárias envolvidas com o PMCMV buscam maximizar seus ganhos tanto na construção quanto na comercialização das unidades produzidas. Dentro dessa lógica elas escolhem os terrenos mais baratos capazes de fornecer uma maior margem de lucro, considerando que elas geralmente trabalham com os tetos de financiamento como valores finais para os imóveis ofertados no mercado (Araújo; Cardoso; Jaenisch $(2013 \text {, p. 3) })^{7}$.

Outros autores afirmam que:

ao tratar como iguais localizações diferentes, a produção habitacional do MCMV em áreas metropolitanas ou municípios conturbados pode viabilizar a geração e incorporação de um excedente, equivalente à diferença entre o 
preço de uma 'pior' localização, escolhida para a produção de empreendimentos, e o preço de uma 'melhor' localização, considerado na composição de custos que definem o limite do valor das unidades habitacionais pelo programa (BALBIM; KRAUSE; NETO, 2013, p. 6$)^{8}$.

Parte desses argumentos podem ser válidos para as faixas 2 e 3, mas, novamente, as empresas que constroem unidades para a faixa 1 não maximizam seus ganhos na comercialização, ou na incorporação, ou ainda na diferença entre o preço de uma pior localização e uma melhor. A construtora é uma prestadora de serviço para a CEF, e essa afirmação é respaldada pelas atribuições das empresas do setor da construção civil estabelecidas na Portaria 168 de 2013. São apenas 3:

apresentar às instituicões financeiras oficiais federais projetos de produção de empreendimentos para alienação dos imóveis; executar os projetos contratados pela instituição financeira oficial federal; realizar a guarda dos imóveis pelo prazo de sessenta dias após a conclusão e legalização das unidades habitacionais. (BRASIL, 2013b, grifo nosso).

Portanto, as empresas que participam da faixa 1 lucram enquanto prestadora de serviço e não enquanto incorporadoras, e parte do pagamento que recebem é estabelecido pelos benefícios e despesas indiretas (BDI) e pela capacidade da empresa de cumprir os prazos da obra (atraso do calendário da obra implica em custos adicionais), de reduzir os custos do canteiro de obra dos empreendimentos, o custo de logística e toda espécie de despesa que não esteja relacionada diretamente com a qualidade dos materiais das unidades isto é, não é possível comprar materiais da construção de menor qualidade apenas para aumentar a margem de lucro, mesmo porque as empresas devem respeitar o Programa Brasileiro da Qualidade e Produtividade do Habitat - PBQP-H.

Outra fonte de maximização de lucro é a empresa construir o máximo possível de UH no terreno escolhido, pois quanto mais unidades construir maior será a sua remuneração. A lógica disso é similar à produção em série das indústrias: a partir do momento que o processo de produção está padronizado e que seus custos foram reduzidos ao máximo possível, a 
empresa lucrará mais quanto mais produzir. Certamente, na prática não é tão simples assim, pois a empresa de construção civil não consegue estabelecer tão facilmente um padrão de produção que minimize os custos. Isto porque, em cada caso, são diferentes os custos de encontrar um terreno e viabilizar a construção do empreendimento: um terreno pode ter problemas ambientais, outro, problemas jurídicos, ou ainda problemas topográficos, e o pior cenário, possuir todos esses empecilhos.

Cada cenário é um caso distinto, e cabe à empresa de construção formular um projeto de empreendimento que resolva os impedimentos que possam existir: ausência de infraestrutura, ou problemas jurídicos. A Caixa recebe a proposta pronta para análise, e na qualidade de agente financeiro, contratará a proposta caso as análises técnicas realizadas pela Gerência de desenvolvimento urbano-engenharia (GIDUR) e pelo jurídico constatarem que todo o projeto está de acordo com as regras do programa. A CEF analisa os seguintes pontos (BRASIL, 2014a, p.12):

\footnotetext{
I. Viabilidade técnica de engenharia, jurídica e, quando for o caso, social;

II. Viabilidade econômica do projeto, se for o caso;

III. Viabilidade das garantias oferecidas para a operação;

IV. Atendimento às demais exigências do programa ao qual o empreendimento esteja vinculado.
}

Vale destacar que na proposta do projeto encaminhado à CEF deve conter também a aprovação do município, o alvará de construção, a aprovação do empreendimento no Grupo de Análise e Aprovação de Projetos Habitacionais do Estado de São Paulo (GRAPROHAB). A empresa proponente deve pedir a aprovação nas empresas responsáveis pelo fornecimento de energia e água (Eletropaulo e Sabesp, por exemplo), e por fim, caso seja necessário, é preciso registrar o condomínio no Cartório de Registro de Imóveis.

Por fim, na faixa 1, a empresa que propõe um projeto arca com todos os custos burocráticos do processo: certidões do terreno, do/a(s) proprietário/a(s), certidões de água e energia, caso não haja alguma infraestrutura, a empresa pode arcar com os custos, ou 
estabelecer um acordo com o poder público local. Além disso, todo o custo da logística de iniciar a obra (montar o canteiro de obra, contratar mão de obra, comprar matérias-primas) é também pago pela empresa. Portanto, é necessário que a empresa que deseja construir um empreendimento tenha alto fluxo de caixa, para conseguir arcar com todos esses custos financeiros, e só começar a receber 1 mês após a obra ter iniciado. Então, mensalmente um técnico da Caixa comparece na obra para fazer a medição, a qual determinará o pagamento da construtora.

Portanto, por meio do termo de adesão ao programa, que estabelece como obrigação o município delimitar ZEIS para receber os empreendimentos do PMCMV, ou mesmo tornar ZEIS, as áreas que já possuem um empreendimento, fica evidente que o poder local tem participação ativa no processo de produção habitacional. Além disso, o poder público local pode doar terrenos ao FAR, prática que ocorreu com frequência na RMSP. Com efeito, Lopes (2014, p. 103) conclui o mesmo para a produção habitacional da região do ABC paulista: "ficou clara a importância do envolvimento direto das Prefeituras Municipais no processo de provisão e no nível de inserção urbana dos empreendimentos”.

Nas faixas 2 e 3 existe o incorporador, o que torna possível a empresa lucrar com a diferença entre o valor pago pelo terreno e o novo valor criado, com a alteração do valor de uso daquela área. A empresa proponente possui liberdade para conceber as características das UH do empreendimento e criar uma estratégia de comercialização. Com efeito, a construção dos empreendimentos para as faixas 2 e 3 é similar a todo o processo de incorporação de um empreendimento focado para famílias que auferem renda superior a 10 salários mínimos, com uma exceção: o PMCMV estabelece também valores máximos que as UH devem ser vendidas, sendo vedado a empresa vender mais caro que o preço estabelecido.

A existência de um valor fixo de venda limita os ganhos advindos da incorporação do empreendimento, porque estabelece um preço total máximo de venda: na RMSP o limite é 
190 mil reais, ou seja, um empreendimento com 100 UH gerará no máximo um valor de 19 milhões, no qual estará incluso o lucro oriundo da incorporação. Além disso, esse fato faz com que seja racional para as empresas economizarem o máximo possível no processo de produção para poder maximizar seus lucros, e também há incentivos tributários e taxas de juros que tornam a construção do empreendimento mais barata: a Instrução Normativa 1.435 (BRASIL, 2014b) estabelece um regime de tributação especial de 1\% das receitas mensais recebidas. Esse regime é válido também para os empreendimentos da faixa 1. Os juros que as empresas pagam para a CEF, durante as fases de carência e amortização, são de $6 \%$ ao mês. Na faixa 1 não há juros, porque, primeiramente, a CEF não faz empréstimo para as construtoras, e, em segundo lugar, as empresas recebem de acordo com a execução da obra.

Embora haja um teto para o preço da venda das unidades, nas faixas 2 e 3, o que limita o valor máximo dos ganhos da incorporação, as empresas adotam uma estratégia para escapar dessa limitação: tanto imóvel na planta como apoio à produção permitem que algumas unidades sejam desligadas do programa. Quando a empresa propõe o projeto à CEF, o financiamento é liberado apenas se a Caixa possuir 100\% da gestão dos recursos referentes aos valores solicitados, parte do qual pode ser fornecido por meio de unidades habitacionais a serem construídas. Se no meio do caminho da construção do empreendimento, a empresa conseguir algum recurso financeiro de outra fonte, pode substituir o valor entregue em unidades pelo valor financeiro, e assim essas unidades desligadas do financiamento não precisam necessariamente ser financiadas pelo PMCMV. Além dessa estratégia, as empresas muitas vezes não comercializam todas as unidades, e fazem um estoque, por exemplo, de 10 moradias, para quando terminarem a obra, poder comercializá-las por um valor superior a 190 mil reais. Portanto, o local que a empresa escolhe para construir os empreendimentos do PMCMV deve possuir um potencial de valorização a médio prazo, e não pode ser totalmente 
desprovido de infraestrutura urbana, ou serviços e equipamentos públicos ou privados, pois diminuiriam as chances de valorização.

\subsection{O processo de aprovação dos projetos de empreendimentos na $\mathrm{CEF}$}

Há também uma diferença no processo de aprovação do projeto do empreendimento apresentado pela empresa de construção à Caixa: na faixa 1, a GIDUR analisa a peça técnica, a capacidade de construção e pagamento da empresa, o jurídico, os aspectos legais do terreno e de seu proprietário. Esses itens são analisados nas faixas 2 e 3, mas todo esse processo é subdividido em 4 etapas: enquadramento, hierarquização, seleção, e contratação da proposta. No enquadramento, a CEF avalia se a proposta do empreendimento se enquadra nos objetivos gerais do programa e nas suas condições de operação. Além desses aspectos mais gerais, cabe à CEF:

\footnotetext{
a verificação da existência de compatibilidade entre o valor de financiamento solicitado e a capacidade de pagamento do proponente; e verificação da viabilidade técnica, comercial, jurídica e econômico-financeira do empreendimento, na forma que vier a ser regulamentada pelo Agente Operador (BRASIL, 2012g).
}

Caso a proposta se enquadre no programa, a próxima etapa é hierarquizar para estabelecer quais projetos são prioritários, ou seja, receberão os recursos financeiros primeiramente para iniciar as obras. São quatro critérios de hierarquização que se equivalem entre si, já a proposta que contemple mais critérios é considerada prioritária, e para efeito de desempate, são considerados na ordem que aparecem na Instrução Normativa 35 e 33 de 2012:

1. Sejam destinadas a famílias com renda mensal bruta de até $\mathrm{R} \$ 3.275,00$ (três mil, duzentos e setenta e cinco reais);

2. Sejam enquadradas no Programa Minha Casa, Minha Vida - PMCMV, de que trata a Lei $\mathrm{n}^{\circ} 11.977$, de 2009;

3. Apresentem maior participação de recursos do proponente em relação ao valor de venda/avaliação das unidades; e

4. Apresentem menor número de unidades (BRASIL 2012f; BRASIL 2012g) 
Depois de enquadradas e hierarquizadas, as propostas são automaticamente selecionadas, e entram na fase da contratação da operação de crédito, e os empreendimentos colocados em primeiro lugar na fila, receberão os recursos, caso comprove:

\begin{abstract}
a. Existência de projeto aprovado e alvará de construção, expedido pelo Órgão Municipal competente;

b. Apresentação de certidão de registro da incorporação para condomínios ou do loteamento, expedida pelo Cartório de Registro de Imóveis competente;

c. Apresentação de memorial descritivo, contendo, no mínimo, as premissas básicas adotadas para elaboração e execução do projeto e o detalhamento de materiais empregados na obra, inclusive seus fornecedores, observado o disposto na alínea "j”, assinado pelo responsável técnico do projeto;

d. Anotação de responsabilidade técnica de execução das obras e dos projetos de arquitetura e complementares e de infraestrutura para loteamentos;

e. Comprovação de regularidade junto à Previdência Social, observada a regulamentação do órgão competente;

f. Comprovação de regularidade junto ao FGTS, mediante apresentação do Certificado de Regularidade do FGTS (CRF) da matrícula no Cadastro Específico do INSS (CEI) do empreendimento ou do Cadastro Nacional da Pessoa Jurídica (CNPJ) da entidade responsável pela produção do imóvel, observado o regime de construção;

g. Existência de vias de acesso, soluções de abastecimento de água e esgotamento sanitário, rede de energia elétrica e iluminação pública, observadas as especificidades locais;

h. "Habite-se" ou documento equivalente expedido pelo órgão municipal competente;

i. Averbação da construção no Cartório do Registro Geral de Imóveis competente;

j. $\quad$ Utilização de materiais cujas especificações técnicas cumpram as normas fixadas pela Associação Brasileira de Normas Técnicas (ABNT), conforme regulamentação. (BRASIL 2012f; BRASIL, 2012g, grifo nosso)
\end{abstract}

Na faixa 1, então, o projeto de empreendimento é aprovado ou não é, mas essa lógica não é válida para faixas 2 e 3, pois o processo é subdividido em enquadramento, hierarquização, seleção e contratação da proposta. Para essa diferença ficar clara é preciso ter em mente a origem dos recursos de cada programa: o PMCMV-faixa 1 recebe recursos financeiros do FAR, ao passo que o PMCMV-faixas 2 e 3, do FGTS. Este fundo, por meio do apoio à produção e do imóvel na planta, financia habitação para o público alvo do FGTS que são as famílias que auferem renda de até $\mathrm{R}$ \$ 4.300,00. 
Quando uma empresa de construção civil apresenta um projeto de empreendimento na linha de financiamento de apoio à produção ou imóvel na planta, a Caixa analisa primeiramente se o projeto pode ser enquadrado nas regras do PMCMV, e para que isso ocorra é necessário que:

5.4 Na forma do art. 73 da Lei $n^{\circ} 11.977$, de 7 de julho de 2009, serão enquadrados no Programa Minha Casa, Minha Vida - PMCMV os empreendimentos que contemplem:

a) condições de acessibilidade a todas as áreas públicas e de uso comum;

b) disponibilidade de unidades adaptáveis ao uso por pessoas com deficiência, com mobilidade reduzida e idosos, de acordo com a demanda;

c) condições de sustentabilidade das construções; e

d) uso de novas tecnologias construtivas. (BRASIL, 2012f, 2012g).

Caso um desses itens não seja contemplado, o projeto não se enquadra no PMCMV, podendo, até, ser aprovado, mas o recurso será liberado de acordo com as regras do FGTS, e não do PMCMV. Isso significa que os mutuários finais não disporão de acesso ao FGHab, descontos nos custos cartoriais, subsídio de até 25 mil e taxas de juros mais acessíveis (varia de $5 \%$ a $7 \%$ ao ano), situações que dificultam a comercialização das unidades construídas. Além disso, as empresas não podem participar do regime especial de tributação aplicado às unidades construídas do PMCMV, o qual estabelece "o pagamento unificado de tributos equivalente a $1 \%$ (um por cento) da receita mensal auferida pelo contrato de construção, de valor comercial" (BRASIL, 2014b).

Portanto, é mais racional à empresa que seus projetos sejam enquadrados no PMCMV para comercializar as unidades com maior facilidade, em virtude dos benefícios oferecidos pelo programa. Outra vantagem está no fato da empresa poder desligar algumas unidades do programa durante a obra, permitindo que sejam comercializadas no futuro, com a expectativa de que haja uma valorização maior, ultrapassando o preço de venda de 190 mil, limite estabelecido pelo PMCMV. Por fim, o regime de tributação especial representa redução de custos para as empresas, fato que possibilita aumentar a margem de lucro. Esses cálculos não estão presentes quando uma empresa de construção civil apresenta um projeto da faixa 1 que 
será apenas aprovado ou recusado pela CEF. A tabela 15 resume os principais pontos de diferença da faixa 1 e faixas 2 e 3 discutidos:

Tabela 15 Resumo das diferenças entre faixa 1 e faixas 2 e 3 (Fonte: Legislação do PMCMV disponível na bibliografia)

\begin{tabular}{|c|c|c|}
\hline Variáveis & Faixa 1 (até $R \$ 1.600$ ) & $\begin{array}{c}\text { Faixa } 2 \text { e } 3 \text { (até } R \$ 5.400 \text { na } \\
\text { RMSP) }\end{array}$ \\
\hline Origem do recurso & FAR e FDS & FGTS \\
\hline Subsídio & $\begin{array}{l}\text { 5\% do salário mensal da família, ou } \\
\text { parcela mínima de } \mathrm{R} \$ 25,00\end{array}$ & $\begin{array}{l}\text { Máximo de } 25 \text { mil, inversamente } \\
\text { proporcional à renda mensal da } \\
\text { família }\end{array}$ \\
\hline Legislação & $\begin{array}{c}\text { Portaria } 168 \text { de } 2013 \text { (FAR), e Instrução } \\
\text { normativa } 14 \text { de } 2013 \text { (FDS) }\end{array}$ & $\begin{array}{l}\text { Instrução Normativa } 33 \text { e } 35 \text { de } \\
2012\end{array}$ \\
\hline $\begin{array}{l}\text { Manual disponibilizado pela } \\
\text { CEF }\end{array}$ & $\begin{array}{l}\text { Far - PMCMV - Manual de Normas e } \\
\text { procedimentos operacionais - MNPO }\end{array}$ & $\begin{array}{l}\text { Manuais de fomrmento pessoa } \\
\text { jurídica - Apoio á produção e } \\
\text { Carta de Crédito Associativo }\end{array}$ \\
\hline Terreno & FAR adquiri & A empresa adquiri \\
\hline Qualidade da localização & $\begin{array}{l}\text { Legalmente, o terreno deve ter vias de } \\
\text { acesso, infraestrutura urbana e } \\
\text { equipamentos públicos. }\end{array}$ & $\begin{array}{l}\text { Legalmente, o terreno deve ter } \\
\text { vias de acesso, infraestrutura } \\
\text { urbana e equipamentos } \\
\text { públicos. }\end{array}$ \\
\hline Paricipação da empresa & Como prestadora de serviço & $\begin{array}{c}\text { Incorporadora com limite de } \\
\text { venda da UH de } 190 \text { mil } \\
\end{array}$ \\
\hline Há incorporação & Não & Sim \\
\hline Processo de aprovação & Único, analisado pela GIDUR e Jurídico & $\begin{array}{l}\text { Dividido em enquadramento, } \\
\text { hierarquização, seleção e } \\
\text { contratação, analisado pela } \\
\text { GIDUR e jurídico }\end{array}$ \\
\hline
\end{tabular}

\subsection{As linhas de financiamentos apoio à produção e imóvel na planta}

O programa de apoio à produção é destinado para pessoas jurídicas do ramo da construção civil que desejam construir um empreendimento para comercializar individualmente as UH. Já a linha de crédito associativo (que recebe o nome comercial de imóvel na planta) é destinada para grupos associativos representados por uma entidade representativa que propõe o projeto de empreendimento. A Instrução Normativa 35 de 2012 (BRASIL, 2012f), considera entidades representativas os condomínios, sindicatos, as 
cooperativas e associações, as pessoas jurídicas voltadas à produção habitacional, ou Companhias de Habitação ou órgãos assemelhados.

O apoio à produção é uma linha de crédito destinada a pessoa jurídica que deseja construir empreendimentos, ao passo que a carta de crédito associativo é uma linha de financiamento para pessoas físicas, organizadas e representadas por uma entidade representativa (pode ser uma construtora, por exemplo), que é responsável por executar a obra. No primeiro caso, a liberação do recurso para a PJ é realizada em função da execução da obra, e no segundo, em função dos financiamentos contratados na CEF. Ademais, na carta de crédito, a entidade executora da obra é remunerada também em função dos contratos de financiamento, num valor de no máximo $4 \%$ do valor contratado. Porém, nos dois casos, $100 \%$ dos recursos dos empreendimentos devem estar sob gestão da Caixa, ou seja, se um empreendimento custar 1 milhão, a empresa responsável pelo projeto deve oferecer contrapartidas no valor de 1 milhão para a Caixa.

Contudo, no caso da carta de crédito, apenas três itens são aceitos como contrapartida: os financiamentos já contratados pela Caixa junto as pessoas físicas, aporte de recursos financeiros na Caixa, ou o porcentual da obra executada - 500 mil em financiamento, 250 mil em aporte, e 250 mil em obra executada, por exemplo. Já no caso de apoio à produção, a construtora pode usar mais elementos para compor os $100 \%$ dos recursos sob gestão da Caixa: os financiamentos podem ser os já firmados com a CEF, ou outra instituição bancária, aportes financeiros e o porcentual da obra são aceitos também, além da fração ideal do terreno e de aporte de recursos financeiros oriundos de outros financiamentos. Além disso, é possível que a PJ representada pela entidade executora do empreendimento, no caso da carta de crédito associativo, também se configure como mutuária final, ou seja, a empresa que constrói um empreendimento pode financiar UH do edifício que está construindo: 
As pessoas jurídicas voltadas à produção habitacional, quando atuando como entidades organizadoras do grupo associativo, poderão figurar como mutuárias, observados os seguintes dispositivos:

a) o percentual máximo das unidades do empreendimento a serem a elas financiado, será definido pelo Agente Operador;

b) as condições operacionais serão aquelas definidas para financiamentos de imóveis novos a pessoas físicas, excetuada a aplicação de descontos; e

c) a transferência dos financiamentos a pessoas físicas ocorrerá em até 180 (cento e oitenta dias) contados a partir da data de expedição do "habite-se" ou documento equivalente expedido por órgão municipal competente (BRASIL, 2012f).

Além da diferença entre o PMCMV-faixa 1, política social que constrói HIS, PMCMV-faixas 2 e 3, e, política de incentivo à construção de HMP, é necessário distinguir apoio à produção e imóvel na planta. Essas duas linhas de financiamentos possibilitam estratégias distintas de atuação para as empresas de construção civil, porém a produção habitacional do primeiro é superior ao do segundo (a nível nacional $68 \%$ na faixa 2 e $85 \%$ na faixa 3 da construção de unidades é do apoio à produção). A tabela 16 resume as principais diferenças.

Tabela 16 Resumo das diferenças entre imóvel na planta e apoio à produção

(Fonte: Legislação do PMCMV disponível na bibliografia)

\begin{tabular}{|c|c|c|}
\hline Variável & Imóvel na Planta & Apoio à produção \\
\hline Alvo & $\begin{array}{c}\text { Famílias que ganham até } \\
\mathrm{R} \$ 5.400\end{array}$ & $\begin{array}{c}\text { Famílias que ganham até } \\
\mathrm{R} \$ 5.400\end{array}$ \\
\hline Subsídio & $\begin{array}{c}\text { Até } 25 \text { mil, invers amente } \\
\text { proporcional à renda } \\
\text { familiar }\end{array}$ & $\begin{array}{c}\text { Até } 25 \text { mil, inversamente } \\
\text { proporcional à renda } \\
\text { familiar }\end{array}$ \\
\hline $\begin{array}{c}\text { Legislação } \\
\text { principal }\end{array}$ & \begin{tabular}{|c|} 
Instrução normativa 35 de \\
2012 \\
\end{tabular} & $\begin{array}{l}\text { Instrução normativa } 33 \text { de } \\
2012 \\
\end{array}$ \\
\hline Manual da CEF & $\begin{array}{l}\text { Manual de fomrmento } \\
\text { pessoa jurídica - Carta de } \\
\text { Crédito Associativo }\end{array}$ & $\begin{array}{c}\text { Manual de fomrmento } \\
\text { pessoa jurídica - Apoio á } \\
\text { produção }\end{array}$ \\
\hline $\begin{array}{l}100 \% \text { de Gestão } \\
\text { dos recursos pela } \\
\text { CEF }\end{array}$ & $\begin{array}{c}\text { Financiamentos a PF, } \\
\text { aporte financeiro, } \% \text { da } \\
\text { obra executada }\end{array}$ & $\begin{array}{c}\text { Financiamentos a PF, } \\
\text { aporte financeiro, \% da } \\
\text { obra executada, Fração do } \\
\text { Terreno, Empréstimo de } \\
\text { terceiros } \\
\end{array}$ \\
\hline Dinâmica & $\begin{array}{c}\text { Grupo organizado, junto a } \\
\text { uma construtora que } \\
\text { propõe o projeto }\end{array}$ & $\begin{array}{l}\text { Empresa da construção } \\
\text { civil propõe o projeto }\end{array}$ \\
\hline Lucro & $\begin{array}{c}4 \% \text { sob o valor dos } \\
\text { financiamentos das UH } \\
\text { junto à CEF, ou/e } \\
\text { incorporação limitada a } \\
190 \text { mil }\end{array}$ & $\begin{array}{c}\text { Incorporação limitada a } 190 \\
\text { mil por UH }\end{array}$ \\
\hline
\end{tabular}




\subsection{As empresas participantes do PMCMV na RMSP}

O fato de na faixa 1 a empresa participar como prestadora de serviço e na faixa 2 e 3 como incorporadora, faz com que haja uma especialização no processo de produção dos empreendimentos: as empresas que atuam na faixa 1 não se arriscam no mercado da faixa 2 e 3, e, se o fazem, criam um novo CNPJ ou participam de uma Sociedade de Propósito Específico (SPE); do mesmo modo, as que atuam na faixa 2 e 3 não constroem empreendimento para a faixa 1, exceto também por meio de novas empresas criadas exclusivamente para essa faixa. A Cury, por exemplo, que foi criada pela Cyrela para atender o mercado de até $\mathrm{R} \$ 1.600$, para atuar na faixa 2 e 3 criou diversas Cias LTDA: IPANEMA, PORTO, ESPERANÇA, MANILHA, PARADA DO SOL, HORTO DO SOL, CCISA, GRAN VIA, PROVINCIA, BNI CURY GUARAPIRANGA. A GOLDFARB INCORPORAÇÕES E CONSTRUÇÕES é outro exemplo dessa estratégia, criando as seguintes SPE-LTDA: GOLD SINGAPURA, GOLD ACAPULCO, GOLD LEROS, GOLD IRLANDA, GOLD LEROS, GOLD TURQUIA, GOLD HOLANDA.

Uma das razões que explica a especialização é o modus operandi da participação da empresa em cada faixa: na faixa 1, as empresas precisam de um fluxo de caixa grande, para arcar com os custos iniciais do projeto, e também precisam se preocupar em economizar na logística da formulação do projeto e no canteiro de obra. É importante respeitar os prazos e encerrar o quanto antes a obra, para iniciar outra, e, assim, sucessivamente. Ainda, a empresa não precisa se preocupar com a comercialização das UHs, com a concepção do projeto (pois já está estabelecido pelo Ministério das Cidades). Nas faixas 2 e 3, ao formular um projeto, a empresa precisa levar em conta que o lucro da incorporação não ultrapassará 190 mil por UH comercializada, e também se preocupar com a concepção do projeto e comercialização. Além 
disso, precisam encontrar qual a melhor forma de entregar à CEF $100 \%$ da gestão dos recursos: qual a proporção de UH precisam financiar, qual a proporção da fração do terreno ideal, ou ainda se desejam fazer um aporte financeiro - vale lembrar que é pré-requisito, para a Caixa aprovar a proposta, possuir 100\% da gestão dos recursos. Desse modo, pode-se dizer que são estilos diferentes de participar do PMCMV e por isso, é necessário haver uma especialização, por mais que sejam criadas duas empresas, com dois CNPJ distintos, a partir de uma única.

É possível demonstrar empiricamente essa diferença. Primeiramente, na RMSP, do ponto de vista do tipo de pessoa jurídica, na faixa 1 participaram do programa LTDA e Entidades, e em menor proporção S.A., ao passo que na faixa 2 e 3, há uma proporção maior de S.A. e apenas nessas faixas existem SPE:

Tabela 17 Produção dos empreendimentos por tipo de Pessoa Jurídica e Faixa - em \% (Fonte: dados da CEF trabalhados pelo CEM)

\begin{tabular}{|l|c|c|c|c|}
\hline TIPO DE PJ & Faixa 1 & Faixa 2 & Faixa 3 & Total Geral \\
\hline LTDA & 51 & 42 & 40 & 44 \\
\hline ENTIDADE & 22 & 1 & 0 & 6 \\
\hline S.A. & 13 & 34 & 35 & 29 \\
\hline LTDA-EPP & 6 & 5 & 3 & 4 \\
\hline LTDA & 4 & - & - & 1 \\
\hline EIRELI & 2 & - & - & 1 \\
\hline EMPRESA PUB & 2 & - & - & - \\
\hline LDTA-EPP & 1 & - & - & - \\
\hline CDHU & - & - & - & - \\
\hline INOCOOP & - & - & - & - \\
\hline LTDA-ME & - & 1 & 1 & 1 \\
\hline SPE-LTDA & - & 16 & 22 & 13 \\
\hline SPE-LTDA-ME & - & 1 & - & - \\
\hline Total Geral & 100 & 100 & 100 & 100 \\
\hline
\end{tabular}

Além disso, de acordo com o ramo de atuação das empresas, cadastrado no CNPJ e disponível no site da Receita Federal, é possível visualizar diferenças entre a faixa 1 e as 
faixas 2 e 3 . Foram selecionadas apenas os três primeiros lugares de cada faixa, pois concentram as maiores quantidades de empreendimentos.

Tabela 18 Produção dos empreendimentos pelo nome do ramo empresarial do registro do CNPJ e Faixa - em \% (Fonte: dados da CEF trabalhados pelo CEM)

\begin{tabular}{|l|r|}
\hline \multicolumn{2}{|c|}{ QUANTIDADE DE EMPRENNDIMENTOS } \\
\hline FAIXA 1 & $\%$ \\
\hline ENTIDADES & 25 \\
\hline CONSTRUTORA E INCORPORADORA & 16 \\
\hline CONSTRUTORA & 15 \\
\hline ENGENHARIA & 6 \\
\hline FAIXA 2 & $\%$ \\
\hline EMPREENDIMENTOS IMOBILIARIOS & 18 \\
\hline ENGENHARIA E PARTICIPACOES & 18 \\
\hline CONSTRUTORA & 10 \\
\hline EMPREENDIMENTO IMOBILIARIO & 5 \\
\hline FAIXA 3 & $\%$ \\
\hline EMPREENDIMENTOS IMOBILIARIOS & 25 \\
\hline ENGENHARIA E PARTICIPACOES & 15 \\
\hline CONSTRUTORA & 10 \\
\hline EMPREENDIMENTO IMOBILIARIO & 4 \\
\hline
\end{tabular}

Como é visível na tabela, a faixa 1 é dominada por construtoras, e a faixa 2 e 3 por empresas de empreendimentos imobiliários, possuindo também uma participação pouca de construtoras. Por fim, é possível notar essa diferença pelas 10 primeiras empresas que mais concentraram empreendimentos na RMSP: as empresas da faixa 1 não se repetem na faixa 2 e 3, e, se pode afirmar também que os empreendimentos na faixa 2 e 3 estão mais concentrados em duas empresas (MRV e Tenda): 
Tabela 19 Produção dos empreendimentos pelo nome da empresa e Faixa - em \% (Fonte: dados da CEF trabalhados pelo CEM)

\begin{tabular}{|c|c|c|c|c|c|}
\hline \multicolumn{2}{|l|}{ Faixa 1} & \multicolumn{2}{|l|}{ Faixa 2} & \multicolumn{2}{|l|}{ Faixa 3} \\
\hline Empresa & $\%$ & Empresa & $\%$ & Empresa & $\%$ \\
\hline CURY & 8 & MRV & 18 & MRV & 15 \\
\hline ESECON & 6 & TENDA & 4 & TENDA & 7 \\
\hline ENPLAN & 4 & BROOKFIELD SAO PAULO & 3 & BROOKFIELD SAO PAULO & 3 \\
\hline FALEIROS & 4 & CR 2 SAO PAULO 1 & 2 & CAPRI & 3 \\
\hline RGA & 4 & GOLDFARB & 2 & FORVALQUATRO & 2 \\
\hline SIMETRICA & 4 & RAIZA & 1 & ARICANDUVA STRIP CENTER & 2 \\
\hline HUDSON & 3 & CRESCER & 1 & FRATTA & 2 \\
\hline SANED & 3 & FORVAL 9 - GUARULHOS & 1 & HOGA & 2 \\
\hline TERRA NOVA & 3 & GALFARO & 1 & PLANO GUAPIRA & 2 \\
\hline $\begin{array}{l}\text { B \& B, BAIRRO } \\
\text { NOVO, CROMA, } \\
\text { WGT, YPS }\end{array}$ & 2 & $\begin{array}{l}\text { GENEA, JARDINS DA } \\
\text { BARRA, NORFOLK, NOVA } \\
\text { DELHI, SERGUS, VNW }\end{array}$ & 1 & $\begin{array}{l}\text { TRISUL, GOLDFARB, ART, } \\
\text { LURE, A VITA, ATUA, ATUA } \\
\text { SPE II, FIT TRINTA E NOVE, } \\
\text { HM DEZESSETE, PLANO IPE, } \\
\text { VIVERE JAPAO, WIP }\end{array}$ & 2 \\
\hline
\end{tabular}

\subsection{A produção habitacional do PMCMV e os lançamentos imobiliários na RMSP}

Esta seção introduz os primeiros dados sobre os empreendimentos do PMCMV na Região Metropolitana de São Paulo, com o objetivo de diferenciar a produção habitacional deste programa da produção habitacional de mercado. Isto é importante, porque afirmar que o PMCMV atende a interesses do mercado ou aos interesses privados das empresas pode gerar a falsa ideia de que é o mesmo tipo de produção habitacional: tanto para famílias que ganham mais do que 10 salários como para as famílias que ganham menos. Foram adotadas duas estratégias nesta dissertação: comparar o padrão de lançamentos imobiliários comerciais na RMSP desde 2009, com o padrão de contratação de unidades habitacionais do PMCMV. Os dados sobre os lançamentos imobiliários foram coletados pela Empresa Brasileira de Patrimônio (Embraesp), e foram aperfeiçoados pela equipe do Centro de Estudos da Metrópole (Cem). Esses dados representam, na sua maioria, a parcela do mercado que o 
PMCMV não atende, ou seja, famílias que ganham mais de 10 salários mínimos. O gráfico 12 demonstra a diferença clara entre as duas produções:

Gráfico 13 Em \% - Lançamentos imobiliários e empreendimento contratados pelo PMCMV (Fonte: banco de lançamentos imobiliários organizado pelo CEM; dados da CEF trabalhados pelo CEM)

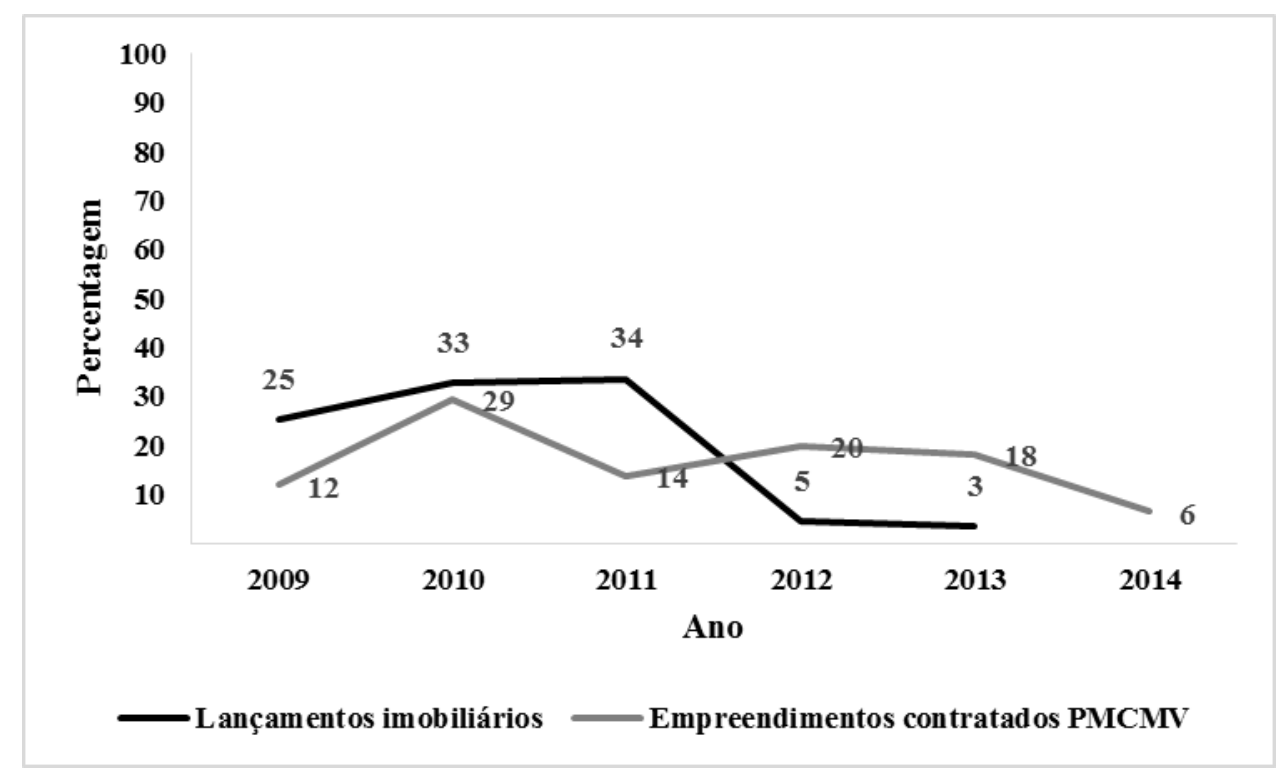

Em termos proporcionais de empreendimentos contratados pelo PMCMV e lançamentos imobiliários, nota-se que esses dois casos possuem dinâmicas diferentes. O único ano em que os números das duas realidades se aproximam é 2010, e a baixa produção habitacional de 2009 é explicada pelo pequeno tempo de existência do PMCMV, que foi lançado no meio do ano. Em 2012 e 2013, enquanto o mercado de lançamentos imobiliários estava em baixa, os empreendimentos do PMCMC estavam em alta. Certamente são necessários mais dados para comprovar a existência de uma diferença entre o mercado do PMCMV e o de lançamentos imobiliários, mas o gráfico 12 demonstra que é uma hipótese pertinente.

Outra forma de destacar a diferença da produção habitacional do PMCMV e dos lançamentos imobiliários para famílias com mais de 10 salários é comparar a evolução do preço do metro quadrado da área útil, e da área total. Como não há dados sobre o preço de 
venda das unidades do PMCMV, nem o preço pago pelo terreno, foi desenhado um cenário hipotético, que possui algumas falhas, mas que representa uma primeira aproximação ao problema. Para calcular esses valores, foi utilizado o banco de dados de lançamentos de empreendimentos imobiliários na RMSP, organizado pelo CEM. Neste banco, há diversas variáveis sobre as características dos lançamentos, e duas dizem respeito ao preço do metro quadrado da área útil e total, atualizados com valores para 2013. Foram realizados dois cálculos: primeiro, calculou-se um raio de 500 metros em torno dos empreendimentos do PMCMV, e todo lançamento imobiliário dentro dessa área teve o valor do metro quadrado útil e total considerado para ser calculada a média de cada valor. O problema do tamanho desse raio é que os conjuntos da faixa 1 não estão tão próximos dos lançamentos imobiliários: para o ano de 2009, apenas um conjunto da faixa 1 estava a pelo menos 500 metros de distância de um lançamento imobiliário, em 2010, 8 conjuntos, e, em 2011, 9 conjuntos - não há empreendimentos da faixa 1 próximos aos lançamentos nos aos de 2012 e 2013.

Devido a essa dificuldade, foi adotado um raio de 4 quilômetros, estratégia que reduz a precisão, pois uma área de 4 quilômetros não é tão contígua a um empreendimento quanto uma de 500 metros, ou mesmo 1 ou 2 quilômetros. Porém, desse modo é possível comparar a evolução da valorização dessa área, tendo como base o valor do metro quadrado útil e total dos lançamentos imobiliários que estão inseridos no raio de 4 quilômetros de distância de cada empreendimento do PMCMV. Além disso, nesse cenário hipotético, os valores absolutos não são tão importantes quanto à distância das curvas no gráfico, pois se pretende com isso ilustrar que as regiões que receberam empreendimentos do PMCMV, num raio de $4 \mathrm{~km}$, sofreram valorização, mas que foi inferior ao mercado de habitação de famílias que ganham mais do que 10 salários mínimos. Outro objetivo é demonstrar que provavelmente a valorização ocorrida nas regiões que receberam empreendimentos das faixas 2 e 3 é superior à região que recebeu empreendimentos da faixa 1 . 
A análise da valorização dos metros quadrados também indica a diferença nos dois tipos de produção habitacional.

Gráfico 14: Evolução da média do valor do metro quadrado útil, pelas faixas do PMCMV, e lançamentos imobiliários (Fonte: banco de lançamentos imobiliários organizado pelo CEM; dados da CEF trabalhados pelo CEM)

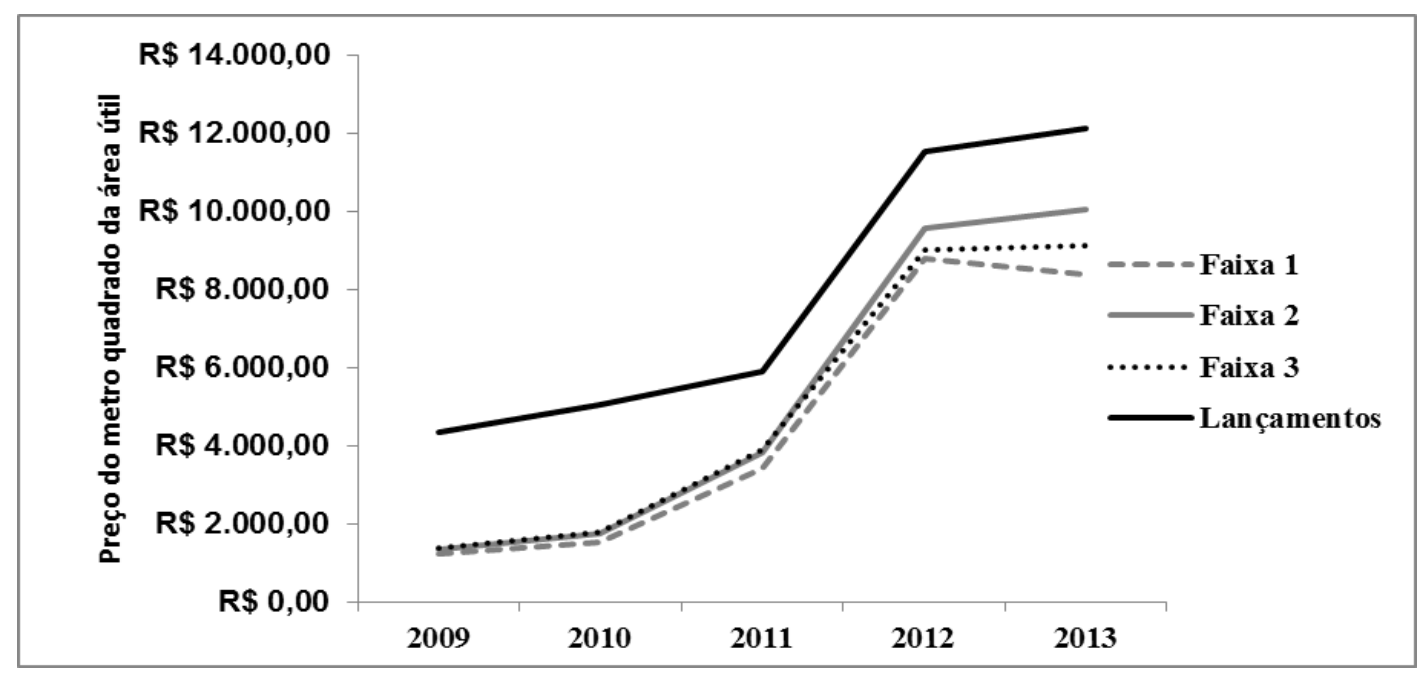

Gráfico 15 Evolução da média do valor do metro quadrado total, pelas faixas do PMCMV, e lançamentos imobiliários (Fonte: banco de lançamentos imobiliários organizado pelo CEM; dados da CEF trabalhados pelo CEM)

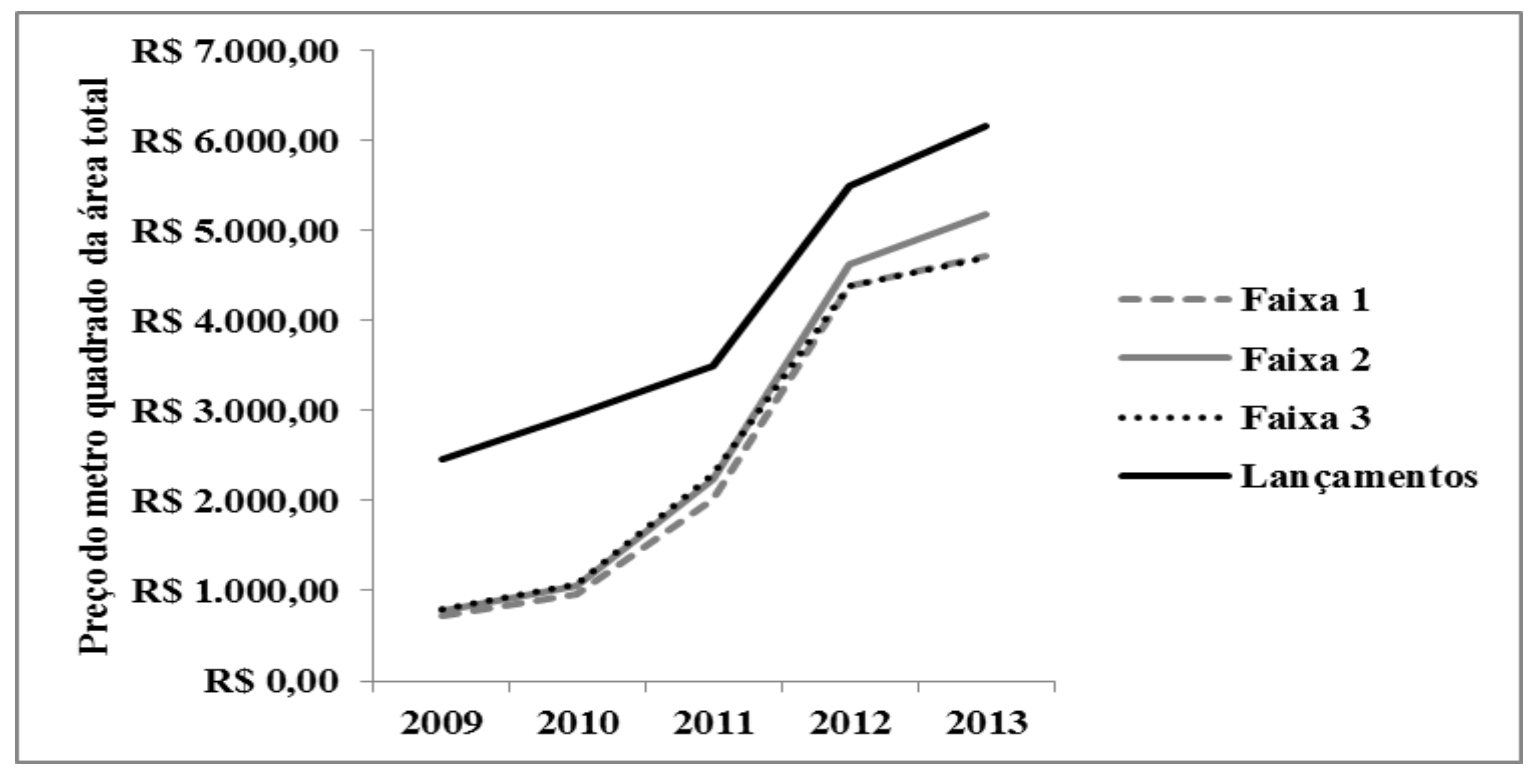


Os valores da média anual do metro quadrado útil e total são maiores nos lançamentos, o que significa dizer que a área de 4 quilômetros que circunscreve cada empreendimento do PMCMV valorizou ao longo dos anos, mas em valores inferiores à média dos lançamentos. No interior do PMCMV, as áreas, nas quais estão inseridos os empreendimentos da faixa 2 foram as que mais se valorizam, tanto no metro quadrado útil como total. As áreas da faixa 3 estão em segundo lugar, quando se analisa o metro quadrado útil, mas no total estão empatadas com as da faixa 1, e as áreas desta encontram-se em terceiro lugar no metro quadrado útil. Vale lembrar que os dados para a faixa 1 podem não condizer com a realidade, porque a área de 4 quilômetros é grande e a quantidade de lançamentos imobiliários que esse raio abarcou é pouca, fato que aumenta a probabilidade de valores extremos alterarem a média.

Esses dados sugerem que ocorreu uma valorização do valor de venda do metro quadrado útil e total dos lançamentos imobiliários, e, que, tal fato atingiu também as regiões (em um raio de 4 quilômetro), nas quais os empreendimentos do PMCMV foram construídos. Portanto, sofreram valorização as áreas, nas quais as unidades habitacionais do programa foram construídas, ou seja, apesar do processo de valorização, as moradias do MCMV foram comercializadas por um valor fixo, sem sofrer ajustes anuais que corrigissem essa valorização. Na verdade, em 2012, foi ajustado o valor limite de venda dos imóveis para as faixas 2 e 3: o Decreto 7.825 de 2012 aumentou, de 170 mil para 190 mil, a venda das unidades em regiões metropolitanas, e a Portaria 521 de 2012 aumentou, de 65 mil para 76 mil, as unidades da faixa 1 - com os 20 mil do Casa Paulista, o valor de venda poderia atingir 96 mil. 


\subsection{Conclusão}

Este capítulo defendeu que as instituições são de suma importância, o que significa também que as regras do jogo importam muito para o processo. Muitas vezes o PMCMV é considerado como um programa de construção de unidades novas para a venda, mas tal afirmação deixa de lado que a Lei que o criou diz que é um programa que incentiva a construção, a aquisição e a requalificação de imóveis. A construção e a requalificação podem ser executadas por uma pessoa jurídica, mas também por uma pessoa física, e a aquisição de um imóvel não precisa ser necessariamente uma unidade de um empreendimento que foi enquadrado no PMCMV.

Na cidade de São Paulo, por exemplo, ocorreu uma requalificação de um edifício na faixa 1, na rua Conselheiro Crispiniano, e talvez haja mais casos em outras metrópoles. Contudo, a produção habitacional da construção deve ser superior à da requalificação, e o fato das regras do jogo permitir que empresas requalifiquem empreendimentos traz a seguinte indagação: porque essa solução não é adotada? Um dos motivos seria a margem de lucro não ser tão alta, ou porque é um processo mais trabalhoso, e a pergunta fica mais interessante quando o poder público local é considerado: no caso da cidade de São Paulo, por exemplo, por qual razão o poder público não incentivou também esse tipo de solução?

Além disso, este capítulo teve como objetivo descrever mais detalhadamente o FARfaixa 1 e Imóvel na Planta e Apoio à Produção (faixas 2 e 3), destacando as diferenças desses três programas, que são diversas: o marco legal, a operação de aquisição dos terrenos, o modo como cada empresa participa do programa (prestadora de serviço e incorporadora), o tipo de empresa que atua na faixa 1 e nas faixas 2, e 3, e, a valorização da área em que foram 
construídos os empreendimentos. Por isso, esta dissertação defende que existem dois PMCMV, um destinado para a faixa 1 e outro, destinado para as faixas 2 e 3.

Essa distinção é essencial para melhor entender as regras do programas, as instituições e os atores que participam do processo de produção da habitação. É preciso levar em conta esses três elementos, pois as empresas de construção civil não constroem os empreendimentos como e onde desejam, tampouco, a Caixa aprova todos os projetos apresentados. As regras existentes proíbem, por exemplo, a construção de um empreendimento em regiões sem infraestrutura urbana, ou equipamentos e serviços públicos. Portanto, existe um quadro legal e institucional que estrutura as ações dos atores no processo de produção das moradias, a partir do qual cada agente atua estrategicamente para maximizar seus benefícios. 


\section{Capítulo 4 A localização dos empreendimentos na RMSP'}

O principal objetivo deste capítulo é analisar a localização dos empreendimentos do PMCMV na RMSP, tendo como ponto de partida o debate sobre segregação urbana. A literatura sobre o programa argumenta que ele viabiliza a construção de empreendimentos distantes dos centros e subcentros urbanos, em áreas com pouca infraestrutura urbana, e serviços e equipamentos públicos. O livro organizado por Cardoso (2013), O Programa Minha Casa Minha Vida e seus efeitos territoriais, aponta diversos argumentos nessa direção e alguns autores chegam à seguinte conclusão: “o Programa Minha Casa Minha Vida [...] intenta reduzir o déficit habitacional ao mesmo tempo em que intensifica o processo de segregação social" (AMORIM; ARAGÃO; ARAÚJO; CARDOSO; JUNIOR; SILVA; 2013, p. 158).

Há então uma relação entre o PMCMV e segregação urbana, que para uns é de intensificação, para outros de vinculação (FREITAS; PEQUENO, 2013) ou aprofundamento (SILVA; SILVA, 2013) desse fenômeno social. Arantes e Fix (2009, grifo nosso) afirmam que

as condições materiais e simbólicas de conjuntos habitacionais desse tipo [do PMCMV], como se sabe, promovem a segregação dos trabalhadores e a falta de qualidades mínimas de vida urbana e serviços públicos

Este capítulo testará empiricamente o argumento da segregação urbana, da disponibilidade de infraestrutura urbana e serviços e equipamentos públicos. Destaca-se inicialmente que, independentemente, do tipo de relação que existe entre o PMCMV e a

$9 \quad$ Parte desse capítulo será publicado em coautoria com o Professor Dr. Eduardo Marques no livro São Paulo, 2010: espaços, heterogeneidade, e espaços na metrópole (MARQUES, 2014). Agradeço todo o grupo que participou do livro pelos debates e sugestões ao capítulo do livro. Quanto ao capítulo da dissertação, os dados foram atualizados, e algumas análises foram adicionadas, como o atendimento do déficit por município, a distância de outros equipamentos, a evolução das distâncias por ano, e a análise das unidades entregues da faixa 1 . 
segregação urbana, falta nesta equação outros agentes, como os municípios, e os estados. Por isso não pode ser afirmado que o programa por si só (ou mesmo as empresas de construção) intensifica, aprofunda ou promove segregação urbana. Tal afirmação desconsidera a participação dos demais atores no processo de produção habitacional, os quais possuem papéis delimitados pelas Portarias, pelas Instruções Normativas e Leis que regem o programa.

Além disso, a produção habitacional do PMCMV na RMSP ocorre em cidades que já possuem um padrão de segregação cristalizado, que foi causado por diversos fatores ao longo da história. Então, além de considerar outros atores envolvidos na produção habitacional do programa, é necessário adicionar a variável histórica, e, a partir desse ponto de vista, é possível afirmar se o PMCMV causa segregação urbana, e como isso ocorre. Além disso, é apresentada neste capítulo uma análise sobre os padrões de atendimento do déficit na RMSP, que, ao contrário do que ocorreu em alguns estados, pouco priorizou a faixa 1. Por fim, alguns dados sobre as unidades habitacionais que foram entregues para as famílias da faixa 1 são apresentados, e destaca-se que houve pouca mistura social, pois a renda média dos responsáveis pelos domicílios no entorno dos empreendimentos são maiores do que a renda familiar declarada pelo mutuário que foi selecionado a habitar na unidade.

\subsection{Considerações conceituais sobre segregação urbana e o PMCMV}

O objetivo desta seção não é resenhar toda a literatura de segregação urbana, ou mesmo descrever os debates e os argumentos usados pelos autores, mas apenas estabelecer uma definição de segregação urbana, e utilizá-la para interpretar alguns elementos empíricos do PMCMV: tanto os aspectos legais do programa, como a produção dos empreendimentos. É possível definir segregação em termos de três processos que podem ocorrer 
concomitantemente: na sua versão mais pura, relaciona-se com total apartamento e isolamento, ou seja, é a criação de guetos, cidadelas, com barreiras físicas que impedem ou dificultam a passagem para fora ou para dentro. Um segundo elemento diz respeito à desigualdade de acesso que pode ocorrer em várias esferas: acesso às políticas públicas, à bens e serviços públicos, etc. Por fim, segregação diz respeito à homogeneidade interna e heterogeneidade externa dos grupos sociais (MARQUES; TORRES, 2005, p. 31-35).

Além disso, é possível identificar quatro grupos de causas da segregação:

a. a dinâmica econômica, o mercado de trabalho e a estrutura social em si;

b. a dinâmica do mercado de terras, as ações dos produtores do espaço urbano e da produção da moradia;

c. o Estado e as políticas públicas;

d. a ordem jurídica brasileira e sua relação com a nossa sociedade em suas dimensões de tradicionalismo, hierarquia social e preconceito. (MARQUES; TORRES, 2005, p. 45).

O PMCMV se relaciona com os três últimos conjuntos de causas, e, conforme, foi demonstrado no capítulo 3, há uma legislação federal clara para atenuar a segregação, porém, dado o arranjo federativo brasileiro, o governo federal não pode interferir, por exemplo, nas Leis de uso do solo, e de zoneamento urbano, pois são prerrogativas municipais. Por isso, o PMCMV pouco pode fazer para evitar a causa do grupo b e d, pois compete ao município legislar sobre aquelas matérias, e também cumprir com o termo assinado para participar do programa. Vale lembrar que, quando um município ou um estado assina o termo de adesão (para a faixa 1), compromete-se a apresentar um relatório de diagnóstico e da demanda por equipamentos e serviços públicos e urbanos, firmar compromisso de instalação desses equipamentos a cada empreendimento implementado, e apresentar projeto de leis que criem ZEIS (BRASIL, 2013c).

Portanto, o Governo Federal criou os mecanismos possíveis para atenuar a segregação, e se o termo de adesão não é respeitado, é preciso investigar o porquê e em qual medida. Além disso, o termo de adesão ao programa concede papel ativo para que os Municípios e os Estados estabeleçam que os empreendimentos sejam bem localizados: “é importante ressaltar 
que são limitadas as possibilidades do governo federal quanto a garantir uma localização adequada dos projetos se os municípios não estiverem dispostos a isso" (BONDUKI, 2009, p.13). Porém, isso é totalmente diferente de afirmar que "os municípios não têm um papel ativo no processo a não ser na exigência de que se cumpra a legislação local” (FIX; ARANTES, 2009).

Se em um Município o termo de adesão não foi respeitado, a causa disso não é porque o poder local tem pouco papel ativo no processo de implementação, mas sim, porque em determinado momento foram escolhidas, pelas empresas, localizações inadequadas, que foram aprovadas pela Caixa e pelo Município. Ao mesmo tempo, o Governo Federal não puniu esse Município, pois cabe ao Ministério das Cidades regular a participação dos Municípios por meio do termo de adesão. Portanto, o causador da segregação não é o PMCMV em si, ou a empresa, pelo contrário, é um arranjo de atores que envolve a Caixa, o Município, a empresa, e o Governo Federal. Cada agente mencionado relaciona-se com as causas da segregação citadas por Marques e Torres (2013): a Caixa e as empresas com a produção do espaço urbano e a dinâmica da terra urbana; a Prefeitura com a ordem jurídica sobre lei de zoneamento e uso do solo, bem como o não cumprimento do termo de adesão; e o Governo Federal, enquanto promotor da política pública, não fiscalizou a observância das regras.

\subsection{Padrões de atendimento do déficit na RMSP}

Até junho de 2014, foram realizadas pela CEF 655 operações de financiamento de empreendimentos imobiliários na RMSP, totalizando 128.899 unidades contratadas pelo PMCMV, das quais até o mês referido, 34.932 já haviam sido entregues e outras 65.352 estavam em obras. Dentre as unidades contratadas, 35,6\% destinam-se para faixa1, 38,9\% 
para a faixa 2, e 25,4\% para a faixa $3(6-10 \mathrm{SM})$. Apenas para estabelecer patamares de comparação, vale reportar que Cardoso, Araújo e Jaenisch (2013) indicam 42.492 unidades construídas na RMRJ, 53\% delas para a faixa 1 . Fortaleza, por outro lado, recebeu 15.285 unidades, sendo $80 \%$ para a faixa 1 (Pequeno, 2013), enquanto Belém teve 7.243 unidades, sendo 49\% para a faixa 1 (Mercês, 2013).

Portanto, a proporção do déficit atendida na faixa 1 é menor na RMSP do que em Fortaleza, Belém e na RMRJ, porém a quantidade do déficit na faixa 1 na RMSP é muito superior do que essas cidades, fato que dificulta o objetivo de reduzir o déficit. Em termos de empreendimentos, a distribuição é um pouco diferente quando se considera os diversos tamanhos médios dos conjuntos. A faixa 1 apresenta, na RMSP, conjuntos um pouco maiores, com 258 unidades, em média, resultando em 178 operações de financiamento. A faixa 2 tem média de 177 unidades e 284 operações, e a última faixa incluía 169 unidades por conjunto e 194 operações.

A redução do déficit habitacional é uma tarefa que demanda tempo e esforços contínuos, e certamente um programa federal que está ativo há 5 anos, não conseguiria reduzir totalmente os números do índice na RMSP. Conforme nota-se no gráfico, o número do déficit mais que duplicou desde 2000 a 2010:

Gráfico 16 Evolução do DH em UH na década de 2000 na RMSP (Fonte: Estudos do déficit habitacional da Fundação João Pinheiro) * Esses anos correspondem ao déficit habitacional total, extraídos da reponderação feita no estudo do DH 2008; ** Esses anos correspondem a

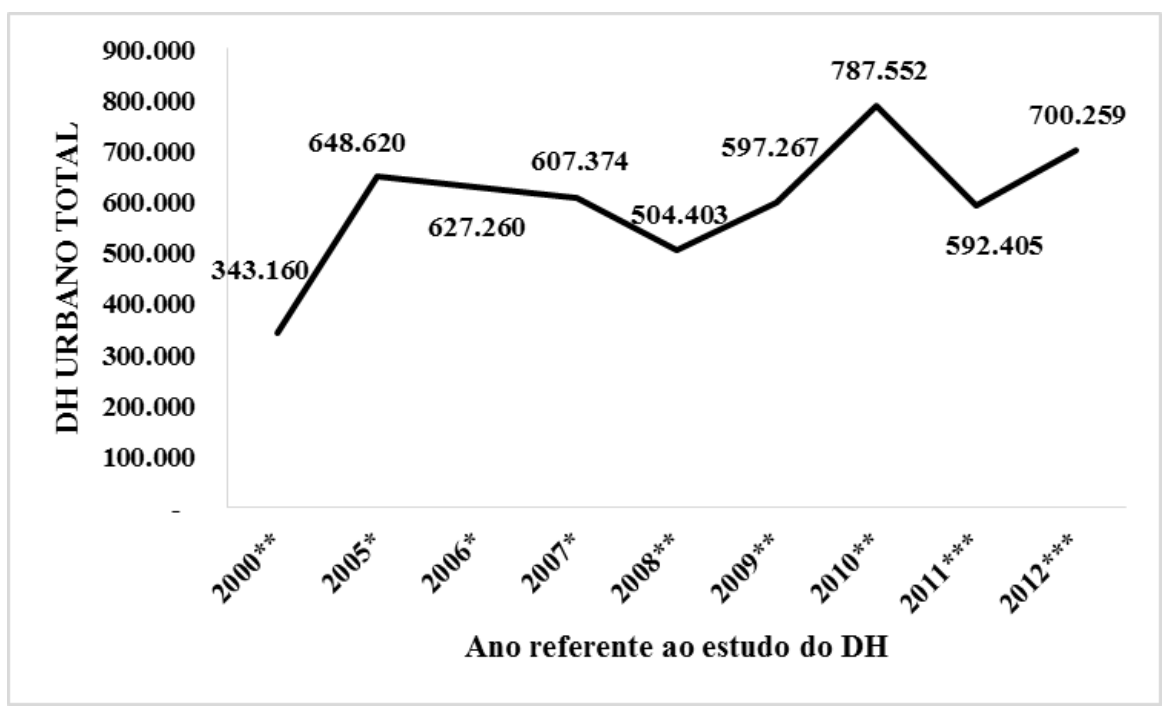


O déficit urbano da RMSP, ao contrário do que ocorreu em nível nacional, possui uma tendência ascendente, e se os dados de 2000 são comparados com os de 2010 (ambos oriundos do Censo), nota-se que o déficit mais que dobrou na metrópole paulista.

Uma das causas disso é que com o surgimento do PMCMV, se tornou viável para muitas famílias adquirirem um imóvel, e, por isso, passaram a declarar nas pesquisas da PNAD e do Censo que desejam constituir uma unidade familiar em uma casa própria. Além dessas considerações, as que foram mencionadas no capítulo 2 são válidas para o caso da RMSP, ou seja, é preciso ter cuidado quando é avaliada a evolução histórica do déficit por três razões: os estudos dos diferentes anos usam amostras de pesquisas distintas; ocorreu uma reponderação para os anos de 2005, 2006, 2007; e, por fim, há uma variação conceitual que altera a operacionalização do conceito.

Dos 787.552, 697.572 corresponde ao déficit nas faixas de 1 a 10 salários mínimos, ou seja, $89 \%$, e $4 \%$ está localizado na faixa das famílias que não possuem renda. Além disso, nem todos os Municípios da região metropolitana que possuem déficit, receberam empreendimentos do PMCM, por isso, o universo do déficit que recebeu unidades habitacionais diz respeito à 684.229 , ou seja, $87 \%$ do total do déficit urbano. Essas considerações são necessárias, porque o déficit analisado diz respeito apenas aos Municipios com empreendimento do PMCMV, razão pela qual, este capítulo menciona sempre 684 mil como o déficit, e não 787 mil (valor total do déficit urbano da RMSP).

Tendo em mente os dados do déficit habitacional de 2010, como se pode interpretar a produção habitacional do PMCMV na RMSP? É tentador indagar se de fato houve a redução do déficit, por mais que a resposta não seja tão precisa quanto à pergunta, pois nem todos os empreendimentos da faixa 1 foram entregues aos mutuários finais, e não há como saber, se dos 700 mil domicílios que compõem o déficit, saiu alguma família para habitar um imóvel 
promovido pelo PMCMV. Portanto, uma análise da relação entre o déficit e os empreendimentos construídos não deve ficar presa aos extremos, mas focar nas nuances que existem, mesmo porque, para um cético, o PMCMV pode ter reduzido pouco o déficit na RMSP, conforme demonstra a tabela:

Tabela 20 DH urbano da RMSP por faixa, produção de unidades pelo PMCMV e proporção do DH atendido (Fontes: Cálculo do CEM a partir de dados da CEF e da FJP)

\begin{tabular}{|c|c|c|c|c|}
\hline & Faixa 1 & Faixa 2 & Faixa 3 & Total \\
\hline Déficit Habitacional Urbano RMSP & 438.213 & 120.903 & 125.113 & 684.229 \\
\hline \% & 64 & 18 & 18 & 100 \\
\hline UH Produzidas na RMSP & 45.932 & 50.146 & 32.821 & 128.899 \\
\hline \% & 35,6 & 38,9 & 25,5 & 100 \\
\hline Proporção do DH atendido (em \% ) & 10 & 41 & 26 & 19 \\
\hline
\end{tabular}

Depreende-se que do total geral, $19 \%$ do déficit pode ter sido atendido pelos empreendimentos do programa habitacional, e na faixa 1, na qual 64\% do déficit se concentra, apenas $10 \%$ foi atingido. Para analisar com mais detalhe a distribuição dos empreendimentos por Municípios e a proporção do déficit habitacional possivelmente reduzido, foram divididas todas as cidades que receberam algum tipo de empreendimento do PMCMV em 5 grupos: o critério utilizado nessa etapa foi a proporção do déficit atendida na faixa 1 . No interior da tabela, são apresentados em ordem crescente os Municípios que mais atingiram o déficit na faixa 1:

Tabela 21 Municípios que não atenderam o DH na faixa 1 (Fontes: Cálculo do CEM a partir de dados da CEF e da FJP)

\begin{tabular}{|c|c|c|c|c|c|}
\hline Municípios & DH 2010 & Faixa 1 & Faixa 2 & Faixa 3 & Total geral \\
\hline \multirow{2}{*}{ Ferraz de Vasconcelos } & DH em UH & 2863 & 967 & 950 & 4781 \\
\cline { 2 - 6 } & $\%$ atendida do DH & 0 & 136 & 32 & - \\
\hline \multirow{2}{*}{ Barueri } & DH em UH & 6556 & 1465 & 1245 & 9266 \\
\cline { 2 - 6 } & $\%$ atendida do DH & 0 & 81 & 18 & - \\
\hline \multirow{2}{*}{ Jandira } & DH em UH & 2088 & 543 & 703 & 3333 \\
\cline { 2 - 6 } & $\%$ atendida do DH & 0 & 77 & 76 & - \\
\hline \multirow{2}{*}{ Franco da Rocha } & DH em UH & 2017 & 659 & 751 & 3427 \\
\cline { 2 - 6 } & $\%$ atendida do DH & 0 & 30 & 0 & - \\
\hline \multirow{2}{*}{ Vargem Grande Paulista } & DH em UH & 806 & 277 & 237 & 1320 \\
\cline { 2 - 6 } & $\%$ atendida do DH & 0 & 29 & 38 & - \\
\hline \multirow{2}{*}{ Santana de Parnaíba } & DH em UH & 1810 & 570 & 624 & 3004 \\
\cline { 2 - 6 } & $\%$ atendida do DH & 0 & 0 & 31 & - \\
\hline \multirow{2}{*}{ São Caetano do Sul } & DH em UH & 3735 & 1006 & 1033 & 5774 \\
\cline { 2 - 6 } & $\%$ atendida do DH & 0 & 0 & 6 & - \\
\hline
\end{tabular}


Esses são os 6 municípios que atenderam alguma proporção do déficit nas faixas 2 e 3, mas simplesmente negligenciaram a faixa 1, embora seja grande a dimensão do déficit nessa faixa para algumas cidades, como é o caso de Barueri, cujo valor é 6.556. Entretanto, Barueri, Ferraz de Vasconcelos, e Jandira obtiveram uma alta proporção do atendimento do déficit nas faixas 2 e 3.

Tabela 22 Municípios que atenderam entre 4\% a 10\% do DH na faixa 1 (Fontes: Cálculo do CEM a partir de dados da CEF e da FJP)

\begin{tabular}{|c|c|r|r|r|r|}
\hline Municípios & DH 2010 & Faixa 1 & Faixa 2 & Faixa 3 & Total geral \\
\hline \multirow{2}{*}{ Itapevi } & DH em UH & 3.999 & 1.328 & 937 & 6.264 \\
\cline { 2 - 6 } & \% atendida do DH & 5 & 27 & - & - \\
\hline \multirow{2}{*}{ São Paulo } & DH em UH & 265.679 & 72.928 & 75.340 & 413.947 \\
\cline { 2 - 6 } & \% atendida do DH & 5 & 27 & 19 & - \\
\hline \multirow{2}{*}{ Osasco } & DH em UH & 17.806 & 4.744 & 4.980 & 27.530 \\
\cline { 2 - 6 } & \% atendida do DH & 6 & 38 & 29 & - \\
\hline \multirow{2}{*}{ Cotia } & DH em UH & 3.942 & 1.185 & 1.294 & 6.421 \\
\cline { 2 - 6 } & \% atendida do DH & 6 & 52 & 94 & - \\
\hline \multirow{2}{*}{ São Bernardo do Campo } & DH em UH & 16.464 & 4.066 & 4.603 & 25.134 \\
\cline { 2 - 6 } & \% atendida do DH & 7 & 45 & 43 & - \\
\hline \multirow{2}{*}{ Carapicuíba } & DH em UH & 8.297 & 2.405 & 2.954 & 13.656 \\
\cline { 2 - 6 } & \% atendida do DH & 10 & 76 & 18 & - \\
\hline
\end{tabular}

Nessa tabela 22, merecem destaques também 3 cidades: Cotia e Carapicuíba, pois ambas atenderam uma parcela do déficit na faixa 1, mas o perfil de atendimento nas faixas $2 \mathrm{e}$ 3 assemelha-se com os de Barueri, Ferraz de Vasconcelos e Jandira, pois todos reduziram o déficit na faixa 2 ou 3 em mais de $70 \%$. A cidade de São Paulo possui o maior déficit habitacional da RMSP, e o atendimento na faixa 1 é de 5,1\%. Isoladamente, esse número é pequeno, mas devemos lembrar que há cidades com um déficit maior do que 2.000 domicílios, e que simplesmente não se preocuparam com essa população. 
Tabela 23 Municípios que atenderam entre 12\% a 20\% do DH na faixa 1 (Fontes: Cálculo do CEM a partir de dados da CEF e da FJP)

\begin{tabular}{|c|c|r|r|r|c|}
\hline Municípios & DH 2010 & Faixa 1 & Faixa 2 & Faixa 3 & Total geral \\
\hline \multirow{2}{*}{ Santo André } & DH em UH & 13.379 & 3.240 & 3.943 & 20.561 \\
\cline { 2 - 6 } & \% atendida do DH & 12 & 49 & 14 & - \\
\hline \multirow{2}{*}{ Diadema } & DH em UH & 11.859 & 2.847 & 2.788 & 17.495 \\
\cline { 2 - 6 } & \% atendida do DH & 12 & 49 & 11 & - \\
\hline \multirow{2}{*}{ Poá } & DH em UH & 2.063 & 702 & 746 & 3.511 \\
\cline { 2 - 6 } & \% atendida do DH & 12 & 35 & 4 & - \\
\hline \multirow{2}{*}{ Francisco Morato } & DH em UH & 2.181 & 854 & 646 & 3.681 \\
\cline { 2 - 6 } & \% atendida do DH & 14 & - & - & - \\
\hline \multirow{2}{*}{ Mauá } & DH em UH & 8.067 & 2.387 & 2.457 & 12.911 \\
\cline { 2 - 6 } & \% atendida do DH & 17 & 97 & 63 & - \\
\hline \multirow{2}{*}{ Embu } & DH em UH & 5.193 & 1.801 & 1.616 & 8.610 \\
\cline { 2 - 6 } & $\%$ atendida do DH & 17 & - & - & - \\
\hline \multirow{2}{*}{ Taboão da Serra } & DH em UH & 5.623 & 1.509 & 1.816 & 8.948 \\
\cline { 2 - 6 } & $\%$ atendida do DH & 19 & 67 & 9 & - \\
\hline \multirow{2}{*}{ Cajamar } & DH em UH & 1.627 & 336 & 308 & 2.271 \\
\cline { 2 - 6 } & $\%$ atendida do DH & 19 & 435 & 545 & - \\
\hline
\end{tabular}

Nesse grupo de cidades, pode-se destacar que Embu e Francisco Morato preocuparamse exclusivamente com o atendimento da faixa 1, sendo que em nenhuma outra cidade dos outros grupos isso ocorreu. Cajamar, por sua vez, é o único município no qual os déficits na faixa 2 e 3 foram ultrapassados muito além dos $100 \%$

Tabela 24 Municípios que atenderam entre 28\% a 38\% do DH na faixa 1(Fontes: Cálculo do CEM a partir de dados da CEF e da FJP)

\begin{tabular}{|c|c|r|r|r|r|}
\hline Municípios & DH 2010 & Faixa 1 & Faixa 2 & Faixa 3 & Total geral \\
\hline \multirow{2}{*}{ Guarulhos } & DH em UH & 29.484 & 7.867 & 8.189 & 45.540 \\
\cline { 2 - 6 } & \% atendida do DH & 29 & 77 & 69 & - \\
\hline \multirow{2}{*}{ Itapecerica da Serra } & DH em UH & 2.690 & 979 & 865 & 4.534 \\
\cline { 2 - 6 } & $\%$ atendida do DH & 30 & - & - & - \\
\hline \multirow{2}{*}{ Itaquaquecetuba } & DH em UH & 6.001 & 1.875 & 1.790 & 9.666 \\
\cline { 2 - 6 } & $\%$ atendida do DH & 33 & 35 & - & - \\
\hline \multirow{2}{*}{ Embu-Guaçu } & DH em UH & 948 & 381 & 415 & 1.744 \\
\cline { 2 - 6 } & $\%$ atendida do DH & 38 & - & - & - \\
\hline
\end{tabular}

Novamente nesse grupo há dois municípios que se preocuparam exclusivamente com a faixa 1: Itapecerica da Serra e Embu-Guaçu. Tal fato ocorre também no próximo grupo de cidades, no qual Guararema conseguiu atingir $100 \%$ do déficit na faixa 1 e Mairiporã $87 \%$. O 
fato de o déficit ser pequeno nessas cidades deve ser levado em conta: certamente construir 500 ou 1.000 unidades habitacionais é mais fácil do que 10 mil ou 100 mil moradias, mas esse resultado é produto de escolhas dos atores envolvidos no processo de implementação do PMCMV, e não do simples fato do déficit ser pequeno nessas cidades. Se quanto menor o déficit na faixa 1 , maior será a probabilidade de reduzi-lo em $100 \%$, então não deveria haver cidades, cujo déficit não ultrapassa 2.000 domicílios, nas quais simplesmente não há uma moradia para faixa 1. Por fim, novamente repete-se o padrão, no qual o déficit na faixa 2 é ultrapassado em mais de 100\% (Mogi das Cruzes e Suzano).

Tabela 25 Municípios que atenderam entre mais de 60\% do DH na faixa 1(Fontes: Cálculo do CEM a partir de dados da CEF e da FJP)

\begin{tabular}{|c|c|r|r|r|r|}
\hline Municípios & DH 2010 & Faixa 1 & Faixa 2 & Faixa 3 & Total geral \\
\hline \multirow{2}{*}{ Suzano } & DH em UH & 4.812 & 1.446 & 1.346 & 7.604 \\
\cline { 2 - 6 } & \% atendida do DH & 63 & 175 & 49 & - \\
\hline \multirow{2}{*}{ Mogi das Cruzes } & DH em UH & 6.522 & 1.887 & 1.965 & 10.373 \\
\cline { 2 - 6 } & \% atendida do DH & 80 & 197 & 84 & - \\
\hline \multirow{2}{*}{ Mairiporã } & DH em UH & 1.257 & 510 & 452 & 2.219 \\
\cline { 2 - 6 } & \% atendida do DH & 88 & - & - & - \\
\hline \multirow{2}{*}{ Guararema } & DH em UH & 446 & 139 & 119 & 703 \\
\cline { 2 - 6 } & \% atendida do DH & 103 & - & - & - \\
\hline
\end{tabular}

Uma comparação entre esses 5 grupos de cidades permite extrair algumas conclusões: primeiramente, não existe um único padrão para o perfil de atendimento do déficit habitacional na RMSP, como poderia ser sugerido, caso ficássemos apenas com a informação de que, em geral, a faixa 2 e 3 teve maior redução do déficit do que na faixa 1 . Os dados demonstram que há municípios que essa proporção se manteve, mas na maioria das cidades o atendimento da faixa 2 é maior do que o da faixa 1, mas este é maior do que o da faixa 3. Deve ser levado em conta, também, que existe a probabilidade de muitas famílias que se enquadrariam na faixa 1 terem optado em migrar para faixa 2, fazendo um reajuste na renda mensal para poder arcar com os custos do financiamento habitacional. São várias as razões dessa escolha: poder escolher a moradia, ter uma unidade habitacional maior, com mais 
benefícios do condomínio, não querer depender do sorteio da Prefeitura, ou ficar na fila de espera.

A segunda conclusão é que são vários os fatores que influenciam no processo de escolha do local para se construir um empreendimento pelo PMCMV. Se de fato fosse um programa guiado pelos interesses do mercado e das incorporadoras, não deveria haver muitas construções para a faixa 1, ou mesmo Município, no qual só há unidades habitacionais para faixa 1 . Ao mesmo tempo, era de se esperar mais cidades, nas quais o atendimento do déficit nas faixas 2 e 3 fosse extrapolado em mais de 100\%, pois são nessas duas faixas que, realmente, há incorporação e que, realmente, há um prevalecimento dos interesses de mercado. Não se nega a existência do interesse pelo lucro das empresas de construção civil, mas não é exclusivamente isso que determinada uma cidade receber ou não um empreendimento do PMCMV: a capacidade da Prefeitura em lidar com problemas habitacionais, a disponibilidade de terra urbana, a disponibilidade de empresas capazes de realizar a construção, o perfil do déficit habitacional. Esses são elementos que podem afetar o sucesso ou o fracasso do PMCMV nos Municípios, e, por sua vez, a redução ou não do déficit habitacional nas faixas 1,2 e 3 .

\subsection{Os subprogramas do PMCMV na RMSP e a localização dos empreendimentos}

Em termos dos subcomponentes do programa, a produção na Região metropolitana de São Paulo envolveu uma distribuição bastante clara. Na faixa 1, a produção do FAR foi amplamente predominante (124 empreendimentos), com FDS-Entidades em um distante segundo lugar (com 42 empreendimentos) e apenas alguns em Urbanização (e 12 empreendimentos). Nas faixas 2 e 3, em primeiro lugar, ficou o Apoio à produção (243 
empreendimentos para a faixa 2 e 163 para a faixa 3), seguido pelo Imóvel na Planta (40 empreendimentos na faixa 2 e 31 na faixa 3). A distribuição das unidades contratadas por municípios é apresentada na tabela a seguir, e representa uma primeira aproximação ao padrão espacial de localização dos empreendimentos.

Tabela 26 Distribuição das UH por município da RMSP e pelo produto da CEF (Fonte: Dados da Caixa Econômica Federal trabalhados pelo CEM, e CENSO 2010) *Urbanização, **Apoio à produção ***Imóvel na Planta ****População Censo 2010

\begin{tabular}{|c|c|c|c|c|c|c|c|c|}
\hline MUNICÍPIO & FAR & FDR & URB* & $\mathbf{A A P} * *$ & IMPL*** & TOT UH & POP $2010 * * * *$ & $\begin{array}{l}\text { DH URBANO } \\
\text { DE } 1 \text { A } 10 \text { SM }\end{array}$ \\
\hline São Paulo & 8.356 & 4.678 & 480 & 29.193 & 4.174 & 46.881 & 11.253 .503 & 413.947 \\
\hline Guarulhos & 7.768 & 778 & & 11.032 & 704 & 20.282 & 1.221 .979 & 45.540 \\
\hline Mogi das Cruzes & 5.240 & & & 5.207 & 160 & 10.607 & 387.779 & 10.373 \\
\hline Suzano & 2.856 & 160 & & 3.189 & & 6.205 & 262.480 & 7.604 \\
\hline Santo André & 1.408 & 240 & & 1.643 & 502 & 3.793 & 676.407 & 20.561 \\
\hline Osasco & 1.122 & & & 2.389 & 851 & 4.362 & 666.740 & 27.530 \\
\hline Mairiporã & 1.100 & & & & & 1.100 & 80.956 & 2.219 \\
\hline Diadema & 832 & 646 & & 1.516 & 180 & 3.174 & 386.089 & 17.495 \\
\hline Carapicuîba & 816 & & & 2.362 & & 3.178 & 369.584 & 13.656 \\
\hline Itaquaquecetuba & 612 & 1.376 & & 648 & & 2.636 & 321.770 & 9.666 \\
\hline Embu & 482 & & 426 & & & 908 & 240.230 & 8.610 \\
\hline Guararema & 460 & & & & & 460 & 25.844 & 703 \\
\hline Embu-Guaçu & 360 & & & & & 360 & 62.769 & 1.744 \\
\hline Cajamar & 311 & & & 2.983 & 160 & 3.454 & 64.114 & 2.271 \\
\hline Francisco Morato & 300 & & & & & 300 & 154.472 & 3.681 \\
\hline Cotia & 256 & & & 1.531 & 300 & 2.087 & 201.150 & 6.421 \\
\hline Poá & 256 & & & 242 & 29 & 527 & 106.013 & 3.511 \\
\hline Itapevi & 181 & & & 359 & & 540 & 200.769 & 6.264 \\
\hline Taboão da Serra & 160 & 884 & & 1.167 & & 2.211 & 244.528 & 8.948 \\
\hline Mauá & 0 & 1.040 & 312 & 3.230 & 631 & 5.213 & 417.064 & 12.911 \\
\hline Barueri & & & & 1.384 & 28 & 1.412 & 240.749 & 9.266 \\
\hline Ferraz de Vasconcelos & & & & 1.617 & & 1.617 & 168.306 & 4.781 \\
\hline Franco da Rocha & & & & 200 & & 200 & 131.604 & 3.427 \\
\hline Itapecerica da Serra & & & 816 & & & 816 & 152.614 & 4.534 \\
\hline Jandira & & & & 826 & 127 & 953 & 108.344 & 3.333 \\
\hline Santana de Parnaíba & & & & 192 & & 192 & 108.813 & 3.004 \\
\hline São Bernardo do Campo & & 800 & 420 & 2.933 & 867 & 5.020 & 765.463 & 25.134 \\
\hline São Caetano do Sul & & & & & 60 & 60 & 149.263 & 5.774 \\
\hline Vargem Grande Paulista & & & & 138 & 32 & 170 & 42.997 & 1.320 \\
\hline Total & 32.876 & 10.602 & 2.454 & 74.053 & 8.914 & 128.899 & 19.212 .393 & 684.229 \\
\hline
\end{tabular}

Como se pode ver, a maior concentração de unidades ocorreu nos municípios de São Paulo, Guarulhos, Mogi das Cruzes, Suzano, Mauá, São Bernardo do Campo, Osasco, Santo André e Cajamar. Esses Municípios são os mais populosos da região metropolitana, cuja lista completa em ordem decrescente inclui São Paulo, Guarulhos, São Bernardo, Santo André, 
Osasco, Mauá, Mogi das Cruzes e Cajamar. O cotejamento das duas listas sugere uma razoável aderência entre a produção dessa política pública e o tamanho do problema a enfrentar, pois quanto maior a população urbana, maior será o déficit habitacional (FUNDAÇÃO JOÃO PINHEIRO, 2012, 2013, 2014). Uma explicação alternativa a essa poderia considerar as alianças políticas entre os prefeitos municipais e o governo federal, promotor do programa. Esses municípios eram governados pelo partido Democratas (São Paulo e Mogi das Cruzes), pelo PT (Guarulhos, Mauá, Osasco, São Bernardo do Campo e Suzano), pelo PSDB (Cajamar) e pelo PTB (Santo André). Embora 5 Prefeituras sejam do PT na lista dos maiores beneficiários, a hipótese de alinhamento político não encontra respaldo no fato de quatro outros Municípios governados pela oposição constarem na mesma lista. Além disso, o único Município dentre os maiores beneficiados que não contava com população expressiva era Cajamar, também governada pela oposição ao Governo Federal. Em geral, portanto, o programa promoveu empreendimentos nos Municípios de maior população da região, exceto por Cajamar e pela posição relativa de Mogi das Cruzes, o que já pode denotar um primeiro sinal de periferização da produção do programa.

Uma primeira abordagem à questão da localização dos empreendimentos pode ser feita com a observação de mapas. Como a distribuição espacial dos empreendimentos varia substancialmente por faixas, optou-se por apresentar a localização de cada faixa em separado. O Mapa 1 apresenta a informação da faixa 1, e como se pode ver, o padrão é periférico, mas também atinge áreas mais consolidadas da periferia. Merecem destaque a região de Itaquera, o extremo da Zona Leste de São Paulo, e o norte da Cidade Tiradentes; em Guarulhos, no Jardim Ângela, no Bairro das Pimentas; em Mogi das Cruzes, em Poá, em Suzano e no ABC Paulista, em especial em Diadema, Santo André e Mauá. Como será demonstrado mais adiante, uma parte importante dessas localizações na periferia se aproxima de conjuntos habitacionais existentes, construídos pela COHAB ou pelo CDHU. Pode-se também observar 
a presença de um empreendimento localizado no centro de São Paulo, na Rua Conselho

Crispiano, no qual estão sendo realizadas obras de reaproveitamento do prédio, ou seja, não se trata da construção de um empreendimento novo.

Mapa 1 Localização dos empreendimentos da faixa 1 do MCMV, RMSP (Fonte: Dados da Caixa Econômica Federal trabalhados em cartografia CEM)

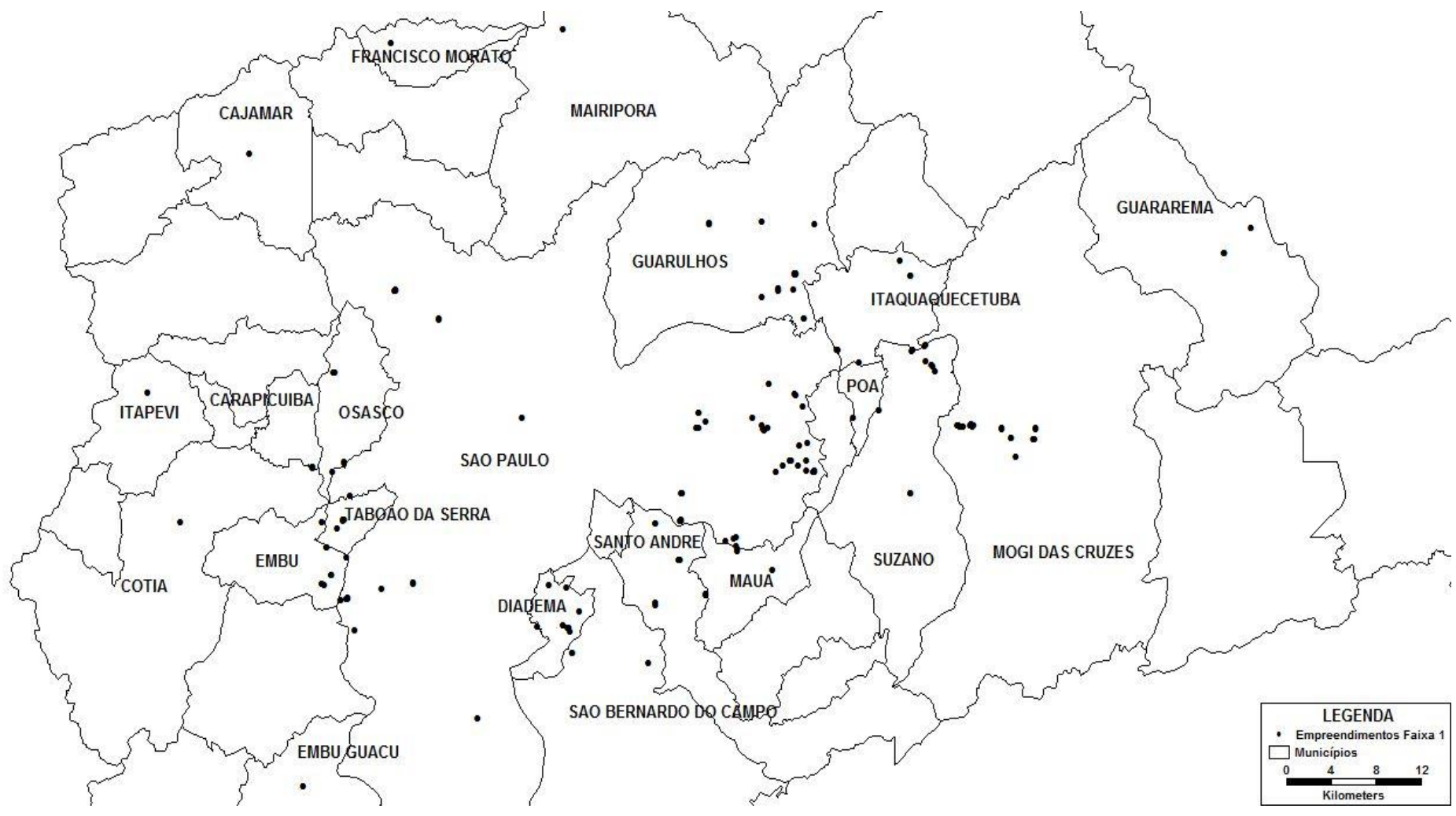

Mapa 2 Localização dos empreendimentos da faixa 2 do MCMV, RMSP (Fonte: Dados da Caixa Econômica Federal trabalhados em cartografia CEM)

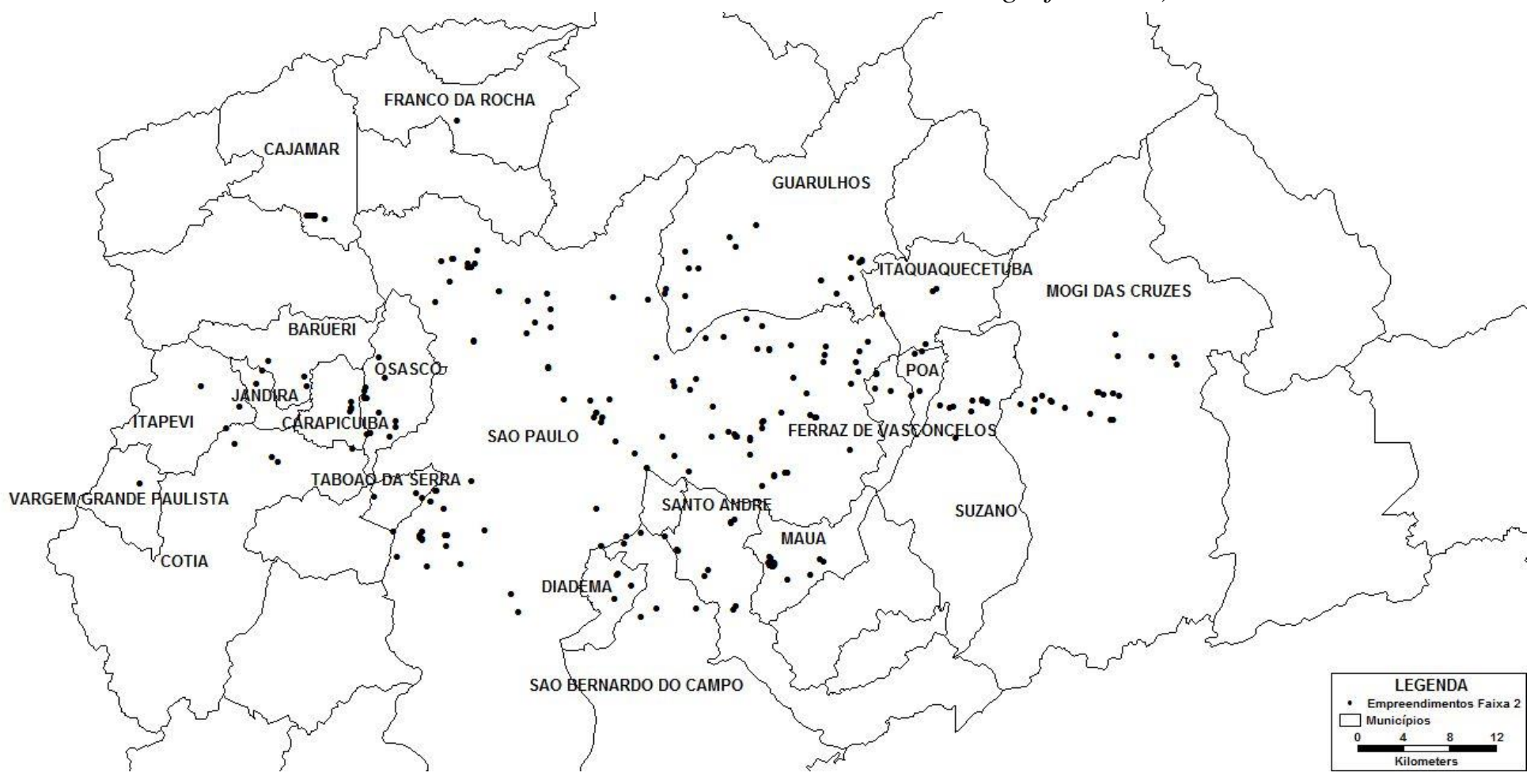


Cardoso, Araújo e Jaenisch (2013) sobre a ausência de empreendimentos nas áreas centrais do Rio de Janeiro. Em São Paulo, não são poucos os empreendimentos das faixas 2 e 3 em áreas do centro tradicional. Contudo, as localizações mais periféricas também se fazem presentes, como um grande aglomerado em Cajamar, e na região oeste em Barueri, Jandira, Itapevi e Osasco; muitos empreendimentos em Mogi das Cruzes, e na região do $\mathrm{ABC}$ Paulista, especialmente em Diadema, São Bernardo, Santo André e Mauá, onde se faz presente outra grande aglomeração. A zona Leste do Município de São Paulo também recebeu muitos empreendimentos, mas em regiões mais consolidadas próximas dos centros de Itaquera e São Miguel Paulista.

\section{Mapa 3 Localização dos empreendimentos da faixa 3 do MCMV, RMSP (Fonte: Dados da Caixa Econômica Federal trabalhados em cartografia CEM)}

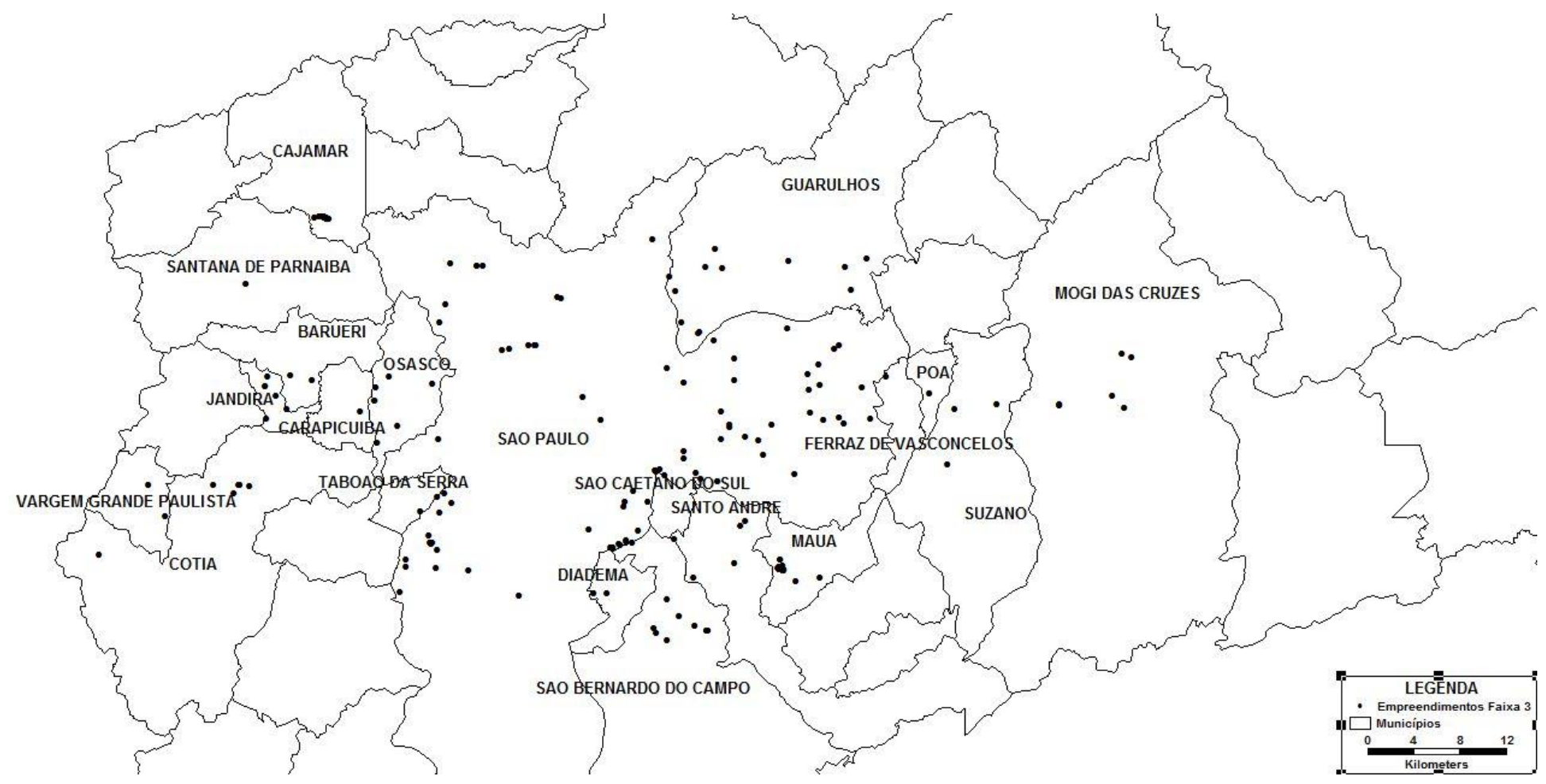

O Mapa 3, por sua vez, apresenta a distribuição dos empreendimentos da faixa 3. Como se pode ver, o padrão é bastante similar ao da faixa 2. Na verdade, é possível dizer que, em termos de macrolocalização, o conjunto dos empreendimentos da faixa 3 é mais periférico 
do que o da faixa 2, ao menos no que diz respeito à presença de conjuntos na região mais interna da metrópole. Chama a atenção também uma menor presença de conjuntos em Mogi das Cruzes. O Mapa indica uma distribuição ampla na zona Leste de São Paulo, no Jardim Ângela, nos Municípios do oeste da Metrópole, em Guarulhos, na região do ABC Paulista, e no Município de São Paulo próximo ao ABC.

Vale ressaltar a presença de agrupamentos de empreendimentos para faixa 2 e $3 \mathrm{em}$ Cajamar, em Mauá, no bairro de Campo Limpo, em alguns pontos da Zona Leste, em São Paulo, em Osasco e Carapicuíba. Os agrupamentos dos empreendimentos para faixa 2 e 3 é diferente do caso quando um único empreendimento possui mais de mil $\mathrm{UH}$, como é o caso do Máximo Guarulhos, por exemplo, empreendimento com 11 torres, com mais de mil UH, destinadas para faixa 2 e 3. Em Cajamar são 14 empreendimentos diferentes, localizados relativamente próximos um dos outros e todos construídos pela BrookField São Paulo Empreendimentos Imobiliários. Além desses, a Camargo Correia também está presente com 4 empreendimentos, por meio de uma Sociedade de Propósito Específico (SPE) chamada HM, os quais também se localizam próximos uns dos outros. Em Mauá, por sua vez, são aproximadamente 29 empreendimentos localizados na mesma região, destinados para faixa 2 e 3, e todos construídos pela MRV.

Esses são casos em que uma área com diversos terrenos é ocupada por uma única empresa de construção civil que constrói diversos empreendimentos próximos uns dos outros. Isso é diferente dos casos na faixa 1, em que algumas empresas priorizam terrenos grandes para construir mais de mil UHs, pois, dessa forma, conseguem maximizar a taxa de lucro. Empresas como a Cury, a Qualyfast, a Dib, e Emccamp adotaram essa estratégia que não é a única possível na faixa 1 , pois existem empresas que construíram empreendimentos para faixa 1 de pequeno porte (não atingindo $100 \mathrm{UH}$ ): a Croma, a Simetrica, e a Enplam. 
É importante destacar a diferença desses dois tipos de aglomeração de empreendimentos: uma é resultado da construção de diversos empreendimentos (com 1 ou mais torres) em terrenos diferentes, mas muito próximos entre si, o que ocorre normalmente nas faixas 2 e 3; a outra é produto de um único empreendimento, construído em um amplo terreno, com várias torres, mas que no processo de financiamento da CEF são subdivididos em diversos empreendimentos. Esse segundo caso ocorre normalmente na faixa 1, e um bom exemplo é o Conjunto Residencial Jundiapeba, em Mogi das Cruzes, que é composto pelos Jundiapebas I, II, III, IV, V, VI, VII, e VIII.

\subsection{Analisando a segregação residencial relacionada ao Minha Casa Minha Vida}

A análise dos padrões de segregação nos conjuntos do MCMV será realizada em várias etapas de detalhamento sucessivo de forma a investigar não apenas a segregação em termos geométricos, mas sócios espaciais, sempre considerando as faixas do programa de forma diferenciada. Primeiramente, avalia-se a escala dos conjuntos. Em segundo lugar, investiga-se a distância dos empreendimentos a centralidades na Região Metropolitana. Em seguida, é demonstrada a distância dos empreendimentos a equipamentos importantes, como as redes do metrô e da CPTM, assim como de conjuntos já construídos pela COHAB e pelo CDHU. Em um terceiro momento, são comparados os conteúdos sociais dos entornos dos empreendimentos para avaliar se a construção dos conjuntos inserirá seus moradores em entornos menos pobres ou mais pobres e precários em termos urbanos.

Com relação à escala dos conjuntos, dentre os empreendimentos contratados, apenas 21 empreendimentos tinham mais de 500 unidades, sendo que três deles tinham mais de 1.400 unidades cada. Entretanto, a mera observação dos números de empreendimentos não 
expressava a concentração espacial dos empreendimentos. São inúmeros os agrupamentos de empreendimentos em locais contíguos, embora por vezes produzidos por empresas distintas. No total, 38 agrupamentos apresentam mais de 500 unidades, sendo o maior deles em Cajamar para as faixas 2 e 3, totalizando aproximadamente 3.200 unidades. Portanto, embora haja conjuntos de grande porte, a maior parte dos empreendimentos não apresenta grande escala.

Para a análise das distâncias das centralidades, considera-se não apenas as distâncias às principais centralidades da Metrópole, mas também a Subcentros Regionais, pois embora a distribuição dos empregos seja fortemente radial e concêntrica a partir do Centro Expandido, diversos outros serviços se encontram disseminados por várias centralidades. Foram consideradas, portanto, não apenas as distâncias às centralidades mais importantes - Praça da Sé (centro histórico) e Berrini-Marginal Pinheiros (atual centro de negócios), mas também à centralidade mais próxima, considerando uma estrutura policêntrica composta de: Praça da Sé, Berrini-Faria Lima e os centros de Santo Amaro, da Penha, de São Bernardo do Campo, de Santo André, de Osasco, de Mogi das Cruzes e de Guarulhos. Vale dizer que as distâncias reportadas dizem respeito a distâncias euclidianas simples entre a localização pontual do empreendimento e a centralidade mais próxima. Como é difícil analisar as distâncias sem um padrão externo de comparação, calculamos e incluímos também na tabela as distâncias de conjuntos da $\mathrm{COHAB}$ e do $\mathrm{CDHU}$ às mesmas centralidades.

A medida estatística utilizada para toda a análise será a mediana, e essa decisão foi tomada a partir da análise das tabelas 27 e 28: é possível notar que é pequena a diferença entre a média e mediana, mas ao mesmo tempo, o valor máximo de cada variável é maior do que a própria média. Esta é uma medida sensível a valores extremos, isto é, os outliers impactam a média, fazendo com que tenha um valor menor ou maior. Além disso, deve-se destacar que, grosso modo, em todos os casos a distribuição dos dados tende a ser mais homogêneas no 
primeiro e no segundo quartil, ao passo que no terceiro e quarto a distribuição é mais heterogênea. É possível notar isso comparando os valores máximos e mínimos com a mediana. Isso sugere que o espectro da distância da primeira metade dos empreendimentos é menor se comparada com a segunda metade, como por exemplo: na faixa 1, a diferença entre o valor mínimo e a mediana é $22 \mathrm{~km}$, e a diferença entre o valor máximo e a media é $43 \mathrm{~km}$. 
Tabela 27 Estatísticas descritivas das distâncias dos empreendimentos do PMCMV (por faixa) às centralidades e aos equipamentos públicos. (Fonte: Dados da CEF, trabalhados sob cartografia do CEM)

\begin{tabular}{|c|c|c|c|c|c|c|}
\hline & \multicolumn{6}{|c|}{ Faixa 1 } \\
\hline & Média & mediana & $\begin{array}{c}\text { Diferença } \\
\text { entre média } \\
\text { e mediana }\end{array}$ & Des vio padrão & $\begin{array}{c}\text { Valor } \\
\text { Máximo }\end{array}$ & $\begin{array}{c}\text { Valor } \\
\text { Mínimo }\end{array}$ \\
\hline Distância da Sé & 25,8 & 22,6 & 3,2 & 10,8 & 65,9 & 0,5 \\
\hline Distância da Berrini & 27,4 & 26,2 & 1,2 & 13,7 & 72,0 & 7,0 \\
\hline Distância da centralidade mais próxima & 10,1 & 9,9 & 0,2 & 5,0 & 29,7 & 0,5 \\
\hline Distância do CEU & 6,6 & 3,4 & 3,2 & 7,7 & 38,8 & 0,2 \\
\hline Distância de Parques & 6,4 & 4,2 & 2,2 & 7,3 & 38,7 & 0,5 \\
\hline Distância da Escolas & 0,6 & 0,3 & 0,3 & 1,4 & 10,8 & 0,0 \\
\hline Distância de Hospitais & 7,6 & 4,8 & 2,8 & 7,8 & 41,3 & 0,8 \\
\hline Distância de Metro & 5,7 & 4,3 & 1,4 & 5,2 & 28,7 & 0,2 \\
\hline Distância de CPTM & 5,0 & 3,7 & 1,3 & 4,0 & 21,6 & 0,8 \\
\hline Distância de Casas e Centros Culturais & 8,6 & 6,7 & 1,9 & 7,9 & 40,9 & 0,2 \\
\hline Distância SESC & 12,2 & 7,4 & 4,8 & 10,1 & 51,1 & 1,0 \\
\hline Distância SESI & 7,8 & 6,4 & 1,4 & 6,0 & 34,9 & 0,4 \\
\hline Distância CDHU & 2,5 & 1,9 & 0,6 & 1,9 & 13,2 & 0,1 \\
\hline \multirow[t]{3}{*}{ Distância COHAB } & 6,6 & 3,8 & 2,8 & 8,0 & 40,9 & 0,0 \\
\hline & \multicolumn{6}{|c|}{ Faixa 2} \\
\hline & Média & mediana & $\begin{array}{c}\text { Diferença } \\
\text { entre média } \\
\text { e mediana } \\
\end{array}$ & Des vio padrão & $\begin{array}{c}\text { Valor } \\
\text { Máximo }\end{array}$ & $\begin{array}{c}\text { Valor } \\
\text { Mínimo }\end{array}$ \\
\hline Distância da Sé & 20,8 & 18,9 & 1,9 & 10,3 & 51,7 & 1,1 \\
\hline Distância da Berrini & 22,8 & 20,9 & 1,9 & 11,7 & 57,1 & 4,4 \\
\hline Distância da centralidade mais próxima & 7,8 & 6,5 & 1,3 & 4,5 & 24,3 & 0,9 \\
\hline Distância do CEU & 6,0 & 4,7 & 1,3 & 5,3 & 25,8 & 0,1 \\
\hline Distância de Parques & 5,1 & 3,9 & 1,2 & 4,9 & 24,6 & 0,1 \\
\hline Distância da Escolas & 0,4 & 0,3 & 0,0 & 0,2 & 1,3 & 0,0 \\
\hline Distância de Hospitais & 6,3 & 4,1 & 2,2 & 5,7 & 27,7 & 0,2 \\
\hline Distância de Metro & 5,8 & 4,1 & 1,7 & 5,6 & 24,8 & 0,2 \\
\hline Distância de CPTM & 3,4 & 2,6 & 0,8 & 2,5 & 11,3 & 0,4 \\
\hline Distância de Casas e Centros Culturais & 7,6 & 6,3 & 1,3 & 6,1 & 27,3 & 0,1 \\
\hline Distância SESC & 9,3 & 7,5 & 1,8 & 7,7 & 35,5 & 0,3 \\
\hline Distância SESI & 6,1 & 5,3 & 0,8 & 3,8 & 19,5 & 0,6 \\
\hline Distância CDHU & 3,1 & 2,6 & 0,5 & 2,5 & 11,5 & 0,1 \\
\hline \multirow[t]{3}{*}{ Distância COHAB } & 5,8 & 4,1 & 1,7 & 5,3 & 26,6 & 0,4 \\
\hline & \multicolumn{6}{|c|}{ Faixa 3} \\
\hline & Média & mediana & $\begin{array}{c}\text { Diferença } \\
\text { entre média } \\
\text { e mediana } \\
\end{array}$ & Des vio padrão & $\begin{array}{c}\text { Valor } \\
\text { Máximo }\end{array}$ & $\begin{array}{c}\text { Valor } \\
\text { Mínimo }\end{array}$ \\
\hline Distância da Sé & 19,5 & 18,3 & 1,2 & 8,5 & 47,0 & 0,5 \\
\hline Distância da Berrini & 20,2 & 19,2 & 0,9 & 9,1 & 52,5 & 7,4 \\
\hline Distância da centralidade mais próxima & 8,1 & 6,9 & 1,2 & 5,0 & 30,6 & 0,5 \\
\hline Distância do CEU & 5,8 & 4,3 & 1,5 & 5,0 & 25,9 & 0,3 \\
\hline Distância de Parques & 5,1 & 4,2 & 0,9 & 4,3 & 21,6 & 0,2 \\
\hline Distância da Escolas & 0,3 & 0,3 & 0,0 & 0,2 & 1,0 & 0,0 \\
\hline Distância de Hospitais & 6,3 & 4,0 & 2,3 & 5,6 & 27,5 & 0,2 \\
\hline Distância de Metro & 7,3 & 4,7 & 2,6 & 6,7 & 28,5 & 0,3 \\
\hline Distância de CPTM & 4,3 & 3,3 & 1,0 & 3,1 & 16,2 & 0,3 \\
\hline Distância de Casas e Centros Culturais & 7,9 & 6,2 & 1,7 & 6,0 & 27,8 & 0,2 \\
\hline Distância SESC & 8,4 & 7,0 & 1,4 & 6,3 & 31,0 & 0,7 \\
\hline Distância SESI & 5,5 & 4,7 & 0,9 & 3,6 & 21,4 & 0,6 \\
\hline Distância CDHU & 3,3 & 2,9 & 0,4 & 2,7 & 15,8 & 0,1 \\
\hline Distância COHAB & 5,8 & 4,8 & 1,0 & 5,0 & 25,8 & 0,3 \\
\hline
\end{tabular}


Tabela 28 Estatísticas descritivas das distâncias de $\mathrm{COHAB}$ e $\mathrm{CDHU}$ às centralidades e aos equipamentos públicos. (Fonte: Dados da CEF, trabalhados sob cartografia do CEM)

\begin{tabular}{|c|c|c|c|c|c|c|}
\hline & \multicolumn{6}{|c|}{ CDHU } \\
\hline & Média & mediana & $\begin{array}{c}\text { Diferença } \\
\text { entre média } \\
\text { e mediana }\end{array}$ & Des vio padrão & $\begin{array}{c}\text { Valor } \\
\text { Máximo }\end{array}$ & $\begin{array}{c}\text { Valor } \\
\text { Mínimo }\end{array}$ \\
\hline Distância da Sé & 21,1 & 19,3 & 1,9 & 8,3 & 65,2 & 9,2 \\
\hline Distância da Berrini & 23,6 & 22,2 & 1,5 & 10,2 & 71,3 & 6,3 \\
\hline Distância da centralidade mais próxima & 10,3 & 9,9 & 0,4 & 5,6 & 30,6 &, 1 \\
\hline Distância do CEU & 6,3 & 3,0 & 3,4 & 8,8 & 61,2 & 1 \\
\hline Distância de Parques & 6,2 & 3,3 & 2,9 & 8,4 & 61,1 & ,2 \\
\hline Distância da Escolas &, 4 &, 2 & 0,2 & ,8 & 10,3 & 0,0 \\
\hline Distância de Hospitais & 4,9 & 2,9 & 2,0 & 5,6 & 40,6 &, 2 \\
\hline Distância de Metro & 6,3 & 3,9 & 2,4 & 5,9 & 33,8 & 2 \\
\hline Distância de CPTM & 3,9 & 2,9 & 1,0 & 3,1 & 21,0 & ,2 \\
\hline Distância de Casas e Centros Culturais & 9,5 & 5,6 & 3,9 & 10,1 & 64,7 & ,2 \\
\hline Distância SESC & 16,6 & 14,3 & 2,4 & 11,0 & 81,1 & 1,4 \\
\hline Distância SESI & 12,1 & 10,4 & 1,7 & 6,9 & 55,0 & ,9 \\
\hline Distância CDHU & - & - & - & - & - & - \\
\hline \multirow[t]{3}{*}{ Distância COHAB } & - & - & - & - & - & - \\
\hline & \multicolumn{6}{|c|}{ COHAB } \\
\hline & Média & mediana & $\begin{array}{c}\text { Diferença } \\
\text { entre média } \\
\text { e mediana }\end{array}$ & Des vio padrão & $\begin{array}{c}\text { Valor } \\
\text { Máximo }\end{array}$ & $\begin{array}{c}\text { Valor } \\
\text { Mínimo }\end{array}$ \\
\hline Distância da Sé & 18,4 & 19,9 & $-1,4$ & 6,1 & 25,9 & 6,3 \\
\hline Distância da Berrini & 20,9 & 21,0 & $-0,1$ & 7,3 & 31,2 & 9,2 \\
\hline Distância da centralidade mais próxima & 10,3 & 10,5 & $-0,2$ & 4,0 & 16,2 & 3,7 \\
\hline Distância do CEU & 3,1 & 2,4 & 0,7 & 2,9 & 15,5 &, 5 \\
\hline Distância de Parques & 2,9 & 2,3 & 0,6 & 2,4 & 12,5 &, 1 \\
\hline Distância da Escolas &, 2 & ,2 & 0,0 & ,2 & ,9 & 0,0 \\
\hline Distância de Hospitais & 2,0 & 1,6 & 0,4 & 1,7 & 9,4 &, 2 \\
\hline Distância de Metro & 3,7 & 2,4 & 1,3 & 3,4 & 15,9 & ,3 \\
\hline Distância de CPTM & 3,7 & 3,4 & 0,3 & 2,0 & 8,1 & ,6 \\
\hline Distância de Casas e Centros Culturais & 4,5 & 3,2 & 1,3 & 4,0 & 18,3 & ,2 \\
\hline Distância SESC & 9,5 & 8,5 & 1,0 & 5,0 & 27,4 & 1,7 \\
\hline Distância SESI & 11,7 & 12,6 & $-0,8$ & 4,4 & 20,2 & 2,2 \\
\hline Distância CDHU & - & - & - & - & - & - \\
\hline Distância COHAB & - & - & - & - & - & - \\
\hline
\end{tabular}


Tabela 29 Distâncias a centralidades por faixas MCMV, Cohab e Cdhu (km) (Fonte: Dados da CEF, trabalhados sobre cartografias CEM)

\begin{tabular}{|c|c|c|c|c|c|c|c|c|c|c|c|c|c|c|c|c|}
\hline & \multicolumn{3}{|c|}{ Faixa 1 } & \multicolumn{3}{c|}{ Faixa 2 } & \multicolumn{3}{c|}{ Faixa 3 } & \multicolumn{3}{c|}{ CDHU } & \multicolumn{3}{c|}{ COHAB } \\
\cline { 2 - 14 } & Média & mediana & $\begin{array}{c}\text { Desvio } \\
\text { padrão }\end{array}$ & Média & mediana & $\begin{array}{c}\text { Des vio } \\
\text { padrão }\end{array}$ & Média & mediana & $\begin{array}{l}\text { Desvio } \\
\text { padrão }\end{array}$ & Média & mediana & $\begin{array}{c}\text { Desvio } \\
\text { padrão }\end{array}$ & Média & $\begin{array}{c}\text { mediana } \\
\text { mesivio } \\
\text { padrão }\end{array}$ \\
\hline Distância da Sé & 25,8 & 22,6 & 10,8 & 20,8 & 18,9 & 10,3 & 19,5 & 18,3 & 8,5 & 21,1 & 19,3 & 8,3 & 18,4 & 19,9 & 6,1 \\
\hline Distância da Berrini & 27,4 & 26,2 & 13,7 & 22,8 & 20,9 & 11,7 & 20,2 & 19,2 & 9,1 & 23,6 & 22,2 & 10,2 & 20,9 & 21,0 & 7,3 \\
\hline $\begin{array}{c}\text { Distância da } \\
\text { centralidade mais } \\
\text { próxima }\end{array}$ & 10,1 & 9,9 & 5,0 & 7,8 & 6,5 & 4,5 & 8,1 & 6,9 & 5,0 & 10,3 & 9,9 & 5,6 & 10,3 & 10,5 & 4,0 \\
\hline
\end{tabular}

Primeiramente, a distância às centralidades dos empreendimentos do MCMV varia entre as faixas, mas tende a ser relativamente estável no interior delas, como atestam os baixos desvios em relação às médias. Os padrões de distância são claramente ordenados, sendo a mais distante a faixa 1 , seja da Sé, seja da Berrini ou das centralidades mais próximas a cada empreendimento mais distante. A faixa 2 e 3 são mais próximas e a diferença entre as duas é maior quando comparadas com a faixa 1 , do que se comparada a faixa 2 com a 3 . Além disso, todas as distâncias caem substancialmente quando se considera as centralidades secundárias: na faixa 1 , de $25 \mathrm{~km}$ para $10 \mathrm{~km}$, na faixa 2, de $21 \mathrm{~km}$ para $7 \mathrm{~km}$, e na faixa $3 \mathrm{de}$ $20 \mathrm{~km}$ para $8 \mathrm{~km}$ - esse mesmo movimento ocorre com os empreendimentos da COHAB e doo CDHU.

As informações relativas a conjuntos da COHAB e do CDHU, entretanto, estabelecem um padrão externo de comparação que acrescenta novas informações. As distâncias médias dos conjuntos existentes na Região Metropolitana de São Paulo variam entre 18 a 24 quilômetros das centralidades mais importantes e aproximadamente 10 quilômetros de qualquer centralidade, valores bastante próximos dos encontrados nos empreendimentos do Minha Casa, Minha Vida, em especial, dos empreendimentos da faixa 1. Empreendimentos da faixa 2 do MCMV, por outro lado, têm padrões de distâncias similares aos conjuntos da COHAB com relação à Sé e à Berrini, mas os empreendimentos da faixa 1 apresentam 
distâncias substancialmente menores (em torno de 8 quilômetros) do que os empreendimentos da COHAB (em torno de 10 quilômetros) no que diz respeito às demais centralidades.

Portanto, em termos de distância a centralidades, os empreendimentos da faixa 1 do MCMV se assemelham bastante a conjuntos da COHAB, e sobretudo do CDHU. Os empreendimentos das faixas 2 e 3 apresentam menores distâncias do que os conjuntos (da COHAB e do CDHU) já existentes na metrópole paulistana. Vale ressaltar que a faixa de renda de atendimento tradicional da $\mathrm{COHAB}$ e do $\mathrm{CDHU}$ não coincidia com a faixa 1 , mas com a faixa 2. Portanto, é com essa faixa que se pode comparar efetivamente as políticas do modelo BNH e, consequentemente, ao menos sob esse ponto de vista, a localização da produção do MCMV é menos periférica que as políticas anteriores.

Além dessas informações, deve-se analisar a evolução das distâncias nos cinco anos de existência do PMCMV. Essas informações são apresentadas em forma de gráfico, e por mais que haja oscilação nos valores entre os anos, é possível notar algumas tendências.

Gráfico 17 Evolução das médias das distâncias às centralidades da Faixa 1 (Fonte: Dados da CEF, trabalhados sobre cartografias CEM)

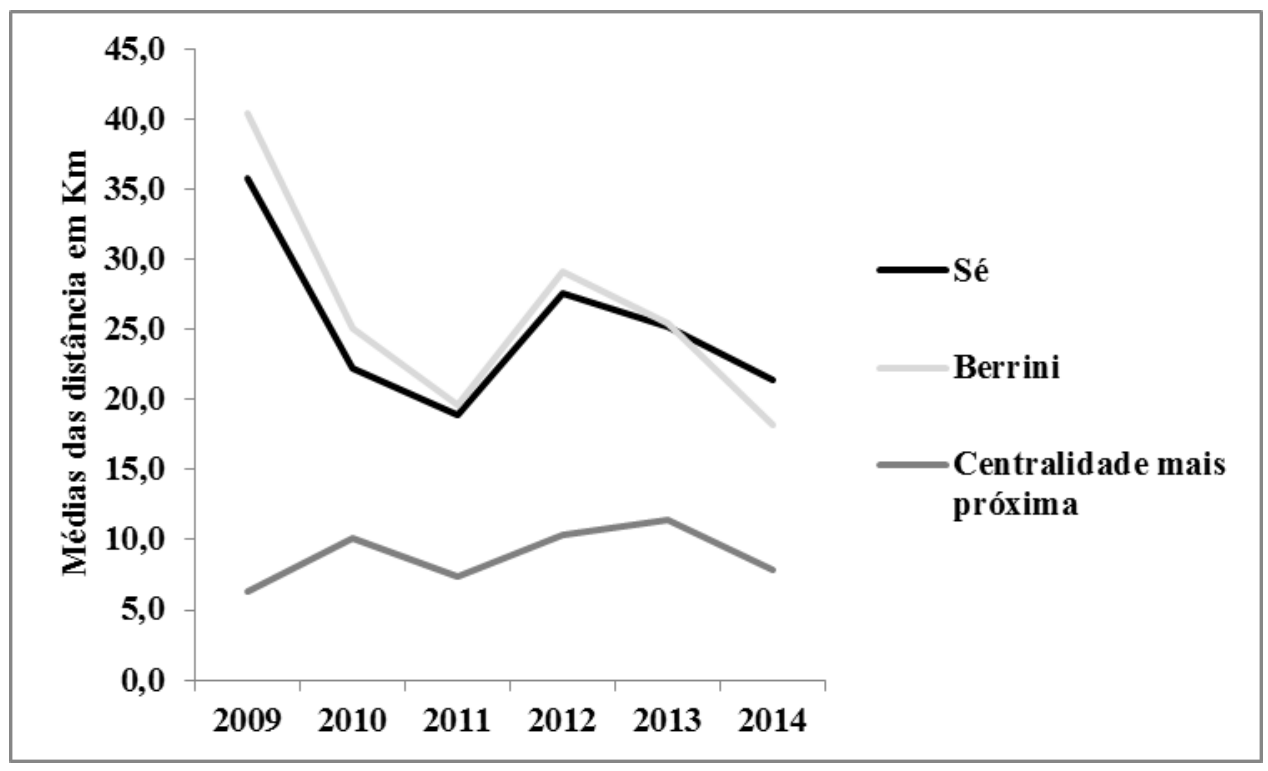

É possível notar duas tendências: primeiramente, há uma queda na média das distâncias para Sé e Berrini, e a partir de 2013 os empreendimentos tendem a ficar mais 
próximos da Berrini do que da Sé. Além disso, a distância média dos empreendimentos se manteve relativamente estável ao longo dos cinco anos, quando consideramos centralidades secundárias - claro que houve oscilações, mas não a ponto de se tornar visível um padrão. A próxima tabela demonstra essas mesmas tendências para a faixa 2.

Gráfico 18 Evolução das médias das distâncias às centralidades da Faixa 2 (Fonte: Dados da CEF, trabalhados sobre cartografias CEM)

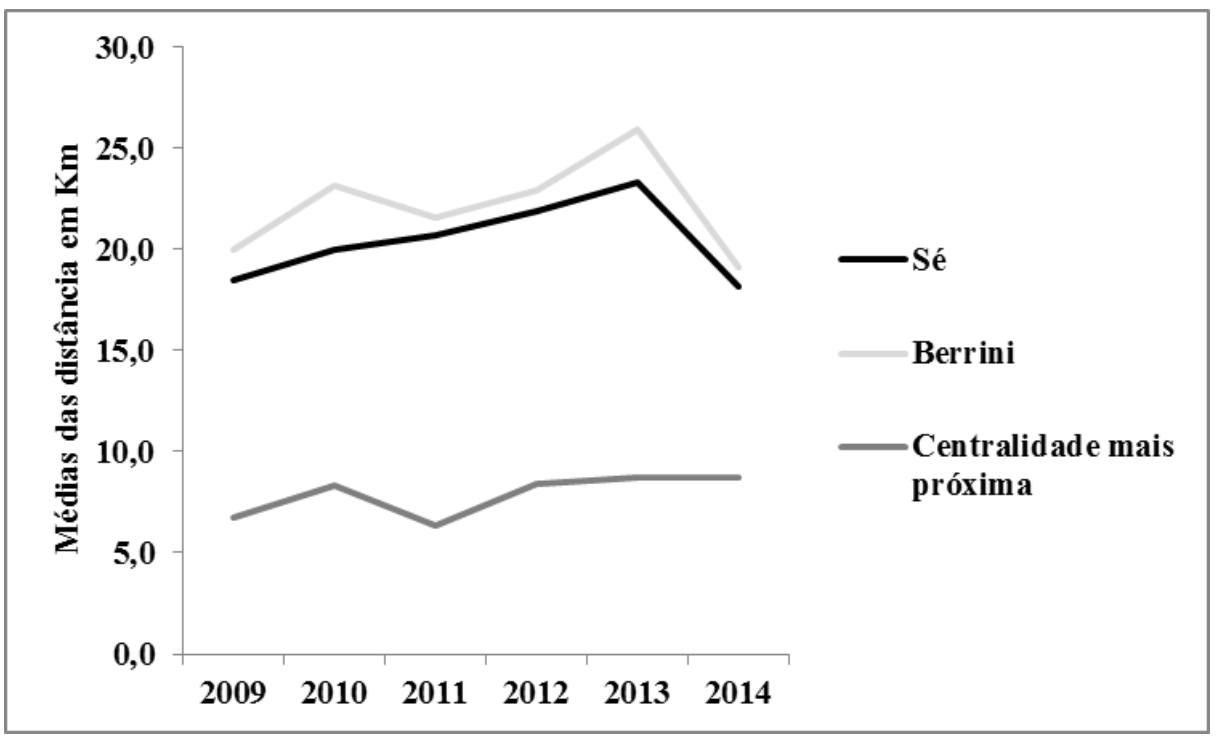

Gráfico 19 Evolução das médias das distâncias às centralidades da Faixa 3 (Fonte: Dados da CEF, trabalhados sobre cartografias CEM)

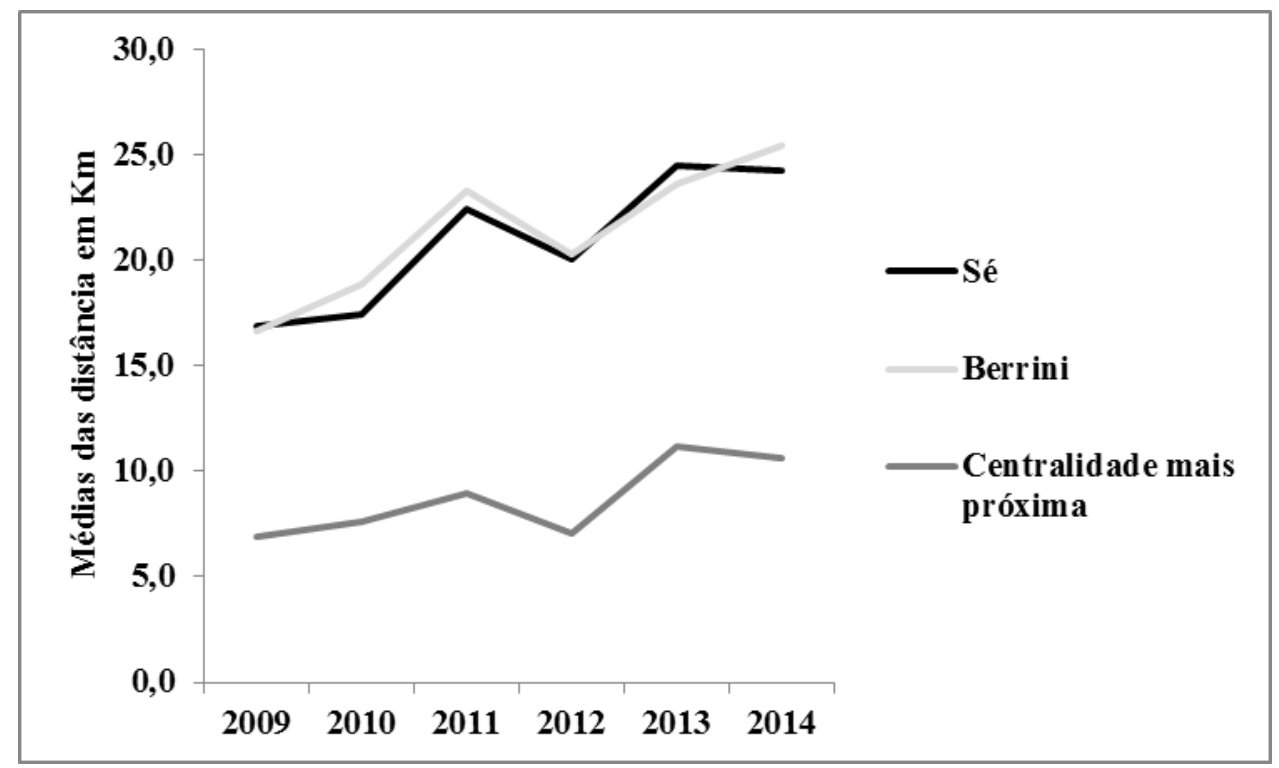


Apenas na faixa 3 ocorreu um aumento nas médias das distâncias, e isso se aplica tanto para Sé, para Berrini como para as centralidades mais próximas. Certamente é difícil prever se essas tendências se manterão ao longo dos próximos anos do programa, e, a queda da média das distâncias à Sé e à Berrini, para a faixa 1e 2, assim como o aumento das médias na faixa 3 só se provarão verdadeiras com a conclusão do programa. Esses gráficos descreveram apenas a evolução desses cinco anos de existência do programa, sem realizar uma afirmação categórica.

É muito diferente estar próximo ou distante a uma centralidade principal ou secundária. Por essa razão, são exploradas as diferentes centralidades presentes no universo de cada faixa. Como se pode ver, as centralidades mais comuns para as três faixas são Guarulhos, Osasco, Mogi das Cruzes, Penha e Santo André, embora com predominância diferente dependendo da faixa. Enquanto para a faixa 1, Mogi e Guarulhos se destaquem, para a faixa 2 o destaque está em Osasco e Penha, e para a faixa 3 em Osasco e Guarulhos. Vale destacar que nesse caso as porcentagens dizem respeito ao número de unidades habitacionais, e não a empreendimentos.

Tabela 30 Distribuição dos centros mais próximos a empreendimentos MCMV, por faixas (\%) (Fonte: Dados da Caixa Econômica Federal, trabalhados sobre cartografias CEM)

\begin{tabular}{|c|c|c|c|c|}
\hline Centralidades & Faixa 1 & Faixa 2 & Faixa 3 & Total Geral \\
\hline Guarulhos & 22 & 14 & 18 & 18 \\
\hline Osasco & 12 & 22 & 21 & 18 \\
\hline Mogi das Cruzes & 24 & 15 & 7 & 16 \\
\hline Penha & 12 & 16 & 16 & 15 \\
\hline Santo Andre & 14 & 13 & 14 & 13 \\
\hline Santo Amaro & 11 & 8 & 9 & 9 \\
\hline São Bernardo & 6 & 5 & 9 & 6 \\
\hline Sé & 0 & 8 & 5 & 4 \\
\hline Berrini & 0 & 0 & 0 & 0 \\
\hline Total Geral & 100 & 100 & 100 & 100 \\
\hline
\end{tabular}

Qual será o padrão de acessibilidade dos empreendimentos a equipamentos? Além disso, como são usados os conjuntos existentes da COHAB e do CDHU como parâmetro, será 
que esses se localizam próximos aos empreendimentos do Minha Casa Minha Vida? Para testar essas dimensões, calculam-se as distâncias euclidianas simples dos empreendimentos do Minha Casa Minha Vida aos seguintes equipamentos: estações do Metrô e da CPTM, escola estadual e municipal, hospital do SUS, CEU, SESI, Casas e centros culturais, SESC, e parques - para os últimos três equipamentos e para o metrô, são utilizadas apenas informações da cidade de São Paulo. Considerando a existência de algumas poucas localizações que fogem ao padrão, são reportadas as medianas, ao invés da média, pois no caso desta dissertação, essa medida descreve mais precisamente os padrões gerais. A mediana é um número que divide em duas metades iguais à amostra utilizada, e vale destacar que no caso do MCMV são 176 empreendimentos na faixa 1, 263 na faixa 2, e 178 na faixa 3; CDHU são 231, e COHAB 55 empreendimentos. Além dessas distâncias, é apresentada também a distância dos empreendimentos do MCMV para os da COHAB e do CDHU, para testar a hipótese se há uma continuidade no espaço entres as moradias.

Tabela 31 Distâncias medianas a conjuntos e equipamentos (Km), por faixa (Fonte: Dados da Caixa Econômica Federal, trabalhados sobre cartografias CEM)

\begin{tabular}{|c|c|c|c|c|c|}
\hline & Faixa 1 & Faixa 2 & Faixa 3 & CDHU & COHAB \\
\hline Distância do CEU & 3,4 & 4,7 & 4,3 & 3,0 & 2,4 \\
\hline Distância de Parques & 4,2 & 3,9 & 4,2 & 3,3 & 2,3 \\
\hline Distância da Escolas & 0,3 & 0,3 & 0,3 &, 2 &, 2 \\
\hline Distância de Hospitais & 4,8 & 4,1 & 4,0 & 2,9 & 1,6 \\
\hline Distância de Metro & 4,3 & 4,1 & 4,7 & 3,9 & 2,4 \\
\hline Distância de CPTM & 3,7 & 2,6 & 3,3 & 2,9 & 3,4 \\
\hline $\begin{array}{c}\text { Distância de Casas e Centros } \\
\text { Culturais }\end{array}$ & 6,7 & 6,3 & 6,2 & 5,6 & 3,2 \\
\hline Distância SESC & 7,4 & 7,5 & 7,0 & 14,3 & 8,5 \\
\hline Distância SESI & 6,4 & 5,3 & 4,7 & 10,4 & 12,6 \\
\hline Distância CDHU & 1,9 & 2,6 & 2,9 & - & - \\
\hline Distância COHAB & 3,8 & 4,1 & 4,8 & - & - \\
\hline
\end{tabular}

Com relação aos equipamentos que podem propiciar lazer, entretenimento, cultura, esportes aos cidadãos e cidadãs, nota-se que com exceção do SESC e SESI, os conjuntos já 
existentes estão mais próximos do que os do PMCMV (para as três faixas), pois 50\% deles (115 para o CDHU e 27 para $\mathrm{COHAB)} \mathrm{estão} \mathrm{mais} \mathrm{próximos} \mathrm{desses} \mathrm{equipamentos.} \mathrm{Além}$ disso, a diferença de distância entre as três faixas não é substantiva para os parques, para as casas e centros de cultura, e para o SESC, mas com relação aos CEUS, os empreendimentos da faixa 1 tendem a se localizar mais próximos, e ao SESI os da faixa 3 estão em uma menor distância. $\mathrm{O}$ acesso às escolas é igual para as três faixas, assim como para o CDHU e a $\mathrm{COHAB}$, e, no que diz respeito ao acesso aos hospitais, pode-se dizer novamente que os conjuntos já existentes estão mais próximos, e no MCMV os empreendimentos da faixa 3 localizam-se na menor distância, sendo a diferença da distância da faixa 1 e 2 pouca - apenas 0,7 Km. As distâncias às estações da CPTM são menores do que as estações do metrô para todas as faixas do MCMV, o que é esperado, considerando o padrão mais periférico da primeira rede. A diferença é superior para empreendimentos das faixas 2 e 3. As distâncias dos conjuntos existentes da COHAB e do CDHU, por outro lado, tende a ser bem inferior a estações de metrô, produto da concentração de conjuntos em Itaquera.

Considerando o desenho do programa, seria de se esperar que empreendimentos da faixa 1 fossem os mais próximos aos conjuntos habitacionais existentes, e que os da faixa 3 fossem os mais distantes, e, que as maiores distâncias ao sistema de transportes fossem observadas com os conjuntos da faixa 1 (e as menores com os da faixa 3). Não é exatamente o quadro que se observa na tabela. Embora empreendimentos da faixa 1 tendam a estar mais próximos dos conjuntos existentes, a diferença da distância dos empreendimentos da faixa $1 \mathrm{e}$ da faixa 3, no que diz respeito ao metrô e à CPTM é pouca, respectivamente: $0,3 \mathrm{Km}$ e 0,5km.

Foi apontado que, de maneira geral, os conjuntos do CDHU e da COHAB tendem a estarem mais próximos dos equipamentos utilizados na medição desta dissertação, mas uma das causas disso é que, proporcionalmente, há mais empreendimentos do PMCMV fora da cidade de São Paulo se comparado com o CDHU, fato que eleva as medidas de distância dos 
empreendimentos do Minha Casa Minha Vida. Para controlar isso, é apresentada uma tabela, organizada das menores distância pela faixa 1, apenas com os conjuntos da COHAB, do CDHU e do PMCMV localizados no município de São Paulo e são utilizados também apenas os equipamentos presentes neste mesmo Município:

Tabela 32 Distâncias medianas a conjuntos e equipamentos (Km) exclusivos da cidade de São Paulo (Fonte: Dados da Caixa Econômica Federal, trabalhados sobre cartografias CEM)

\begin{tabular}{|l|c|c|c|c|c|}
\hline & Faixa 1 & Faixa 2 & Faixa 3 & CDHU & COHAB \\
\hline Distância Parques & 1,4 & 1,4 & 1,9 & 2,0 & 2,3 \\
\hline Distância CEU & 1,7 & 2,3 & 2,1 & 2,0 & 2,4 \\
\hline Distância Hospitais & 1,9 & 1,8 & 1,8 & 2,0 & 1,6 \\
\hline Distância Metro & 2,2 & 2,3 & 2,8 & 3,0 & 2,4 \\
\hline $\begin{array}{l}\text { Distância Casas e } \\
\text { Centros de Cultura }\end{array}$ & 3,4 & 2,2 & 3,2 & 4,0 & 3,2 \\
\hline Distância SESC & 5,7 & 3,7 & 4,4 & 12,0 & 8,5 \\
\hline Distância Sé & 21,1 & 15,3 & 14,2 & 17,0 & 19,9 \\
\hline Distância Berrini & 22,1 & 16,1 & 14,5 & 21,0 & 21,0 \\
\hline
\end{tabular}

Foram adicionadas também as duas centralidades importantes do Município, e se nota que de fato os empreendimentos da faixa 1 são os mais distantes, já os mais próximos da centralidade da Sé são os conjuntos do CDHU. A explicação disso é a alta concentração de muitos conjuntos nos seguintes bairros periféricos, mas não tão distantes da Sé: Brasilândia, Jaraguá e Pirituba, na zona Norte, Socorro, na zona Sul, e Itaquera, Vila Jacuí, José Bonifácio, e Cangaíba, na zona Leste. Os empreendimentos da faixa 2 e 3 estão mais dispersos na cidade de São Paulo, com alguns pontos com concentração de empreendimentos, como em Campo Limpo e em Sacomã, zona Sul, Cidade Tiradentes, zona Leste. A maior dispersão dos empreendimentos da faixa 2 e 3 somada com a concentração de alguns empreendimentos em bairros mais distantes (do que os do CDHU) faz com que a mediana seja maior para esses empreendimentos.

Por fim, é importante destacar que o CDHU não construiu nenhum empreendimento na região central da cidade de São Paulo, e na faixa 2 e 3, é possível encontrar empreendimentos na República, no Ipiranga, no Cambuci, na Água Rasa, na Barra Funda e no 
Brás - sem mencionar a reutilização do edifício na Rua Conselheiro Crispiniano para a faixa 1. O argumento que explica a menor distância dos empreendimentos da $\mathrm{COHAB}$ é um pouco diferente: o único ponto de concentração de conjuntos é a Cidade Tiradentes, ao passo que os outros conjuntos estão dispersos em bairros com distâncias semelhantes da Sé, sendo que a quantidade de empreendimento é 3 vezes menor que o da faixa 1, por exemplo.

Com relação às distâncias dos parques, nota-se que a diferença é pouca entre os empreendimentos do PMCMV, ou mesmo quando são comparados com os conjuntos da COHAB e do CDHU. Para as Casas e centros de cultura, a diferença é um pouco maior, sendo que as unidades da $\mathrm{COHAB}$ estão mais próximas, seguidas da faixa 2, do CDHU, da faixa 3 e faixa 1, mas a diferença do primeiro colocado para o último é apenas 1,4 km. Com relação aos SESCs, a ordem de classificação é a seguinte: faixa 2, faixa 3, COHAB, faixa 1 e CDHU, e neste caso, a diferença do primeiro lugar para o quarto (faixa 2 - faixa 1) é de apenas $1 \mathrm{~km}$, mas a diferença é bem maior entre o primeiro e o último - 3,9 km. Por fim, com relação à estação de metrô, os empreendimentos para a faixa 3 são os mais distantes $(2,8 \mathrm{~km})$, e a diferença entre o faixa 1 e a COHAB é apenas $0,7 \mathrm{~km}$.

Segregação residencial diz respeito à homogeneidade de conteúdos sociais das áreas da cidade, separados por distâncias de outros espaços também homogêneos. Desse modo, outra forma de se acessar as dimensões relativas à segregação é comparando as características dos entornos dos empreendimentos com aquelas que se pode imaginar serem as dos futuros moradores dos empreendimentos. As ferramentas de geoprocessamento auxiliam nisso mais uma vez, pois é possível gerar estimativas a partir dos dados do Censo de 2010 das características sociais dos moradores dos entornos dos empreendimentos a uma dada distância. No caso, foi utilizado um entorno de 1000 metros, a mesma distância que a Portaria 168 de 2013 considera para classificar os empreendimentos contíguos na faixa 1. A tabela a seguir apresenta a informação, incluindo dados similares relativos a conjuntos da COHAB e 
do CDHU e para o conjunto da região metropolitana, para estabelecer parâmetros de comparação.

Tabela 33 Características sociais médias dos entornos (1000 metros) do MCMV, COHAB, CDHU e RMSP, 2010 (Fonte: Dados da Caixa Econômica Federal, trabalhados sobre cartografias CEM)

\begin{tabular}{|c|c|c|c|c|c|c|}
\hline & \multicolumn{3}{|c|}{ Minha Casa, Minha Vida } & \multirow{2}{*}{ CDHU } & \multirow{2}{*}{ COHAB } & \multirow{2}{*}{ RMSP } \\
\hline & Faixa 1 & Faixa 2 & Faixa 3 & & & \\
\hline \multicolumn{7}{|l|}{ Características sociais } \\
\hline Renda média & $\mathrm{R} \$ 1.187$ & $\mathrm{R} \$ 1.640$ & $\mathrm{R} \$ 1.713$ & $\mathrm{R} \$ 1.284$ & $\mathrm{R} \$ 1.235$ & $\mathrm{R} \$ 2.029$ \\
\hline $\begin{array}{l}\text { Pessoas responsáveis com rendimento nominal } \\
\text { mensal de até } 1 / 2 \text { salário mínimo - em \% }\end{array}$ & 2,1 & 1,3 & 1,1 & 1,5 & 1,5 & 1,2 \\
\hline Anos médios de estudo - em anos & 6,9 & 8,0 & 8,1 & 7,1 & 7,1 & 8,7 \\
\hline $\begin{array}{c}\text { Alfabetizados de pessoas entre } 5 \text { a } 9 \text { anos - } \\
\text { em \% }\end{array}$ & 6,6 & 6,0 & 5,9 & 6,3 & 6,5 & 76,1 \\
\hline Pessoas com menos de 10 anos - em \% & 17,8 & 15,7 & 15,3 & 17,0 & 17,4 & 14,2 \\
\hline Pessoas com mais de 65 anos - em $\%$ & 4,6 & 6,5 & 6,8 & 5,1 & 5,3 & 8,5 \\
\hline População em setores subnormais - em \% & 12,0 & 8,6 & 9,0 & 10,8 & 11,3 & 3,3 \\
\hline \multicolumn{7}{|l|}{ Domicílios e infraestrutura } \\
\hline Domicilio próprio em aquisição - em \% & 12,1 & 11,3 & 11,7 & 18,8 & 19,6 & 23,0 \\
\hline Domicílio alugado - em \% & 17,2 & 20,4 & 20,9 & 17,5 & 17,3 & 7,6 \\
\hline Domicilio com água da rede - em \% & 97,8 & 99,1 & 98,7 & 98,0 & 99,1 & 98,9 \\
\hline Domicilio com esgoto e sanitário exclusivo & 83,9 & 89,6 & 88,9 & 87,8 & 90,8 & 92,0 \\
\hline $\begin{array}{l}\text { Domicilio com serviço de lixo por caminhão - } \\
\%\end{array}$ & 94,3 & 95,1 & 93,5 & 93,6 & 93,3 & 80,1 \\
\hline $\begin{array}{c}\text { Domicilio com serviço de lixo por caçamba - } \\
\%\end{array}$ & 2,9 & 3,1 & 3,6 & 5,0 & 6,2 & 2,7 \\
\hline $\begin{array}{c}\text { Domicilio com energia rede, medidor exclusivo } \\
-\%\end{array}$ & 80,8 & 85,5 & 86,4 & 84,9 & 84,5 & 86,7 \\
\hline \multicolumn{7}{|l|}{ Entomo dos domicílios no setor censitário } \\
\hline Existe identificação do logradouro - em \% & 83,1 & 88,9 & 89,7 & 88,2 & 89,8 & 88,0 \\
\hline Existe identificação do logradouro - em \% & 96,3 & 98,2 & 98,3 & 96,7 & 96,6 & 96,6 \\
\hline Existe pavimentação - em \% & 93,2 & 97,1 & 96,8 & 95,6 & 96,7 & 95,8 \\
\hline Existe calçada - em \% & 85,3 & 91,6 & 89,9 & 90,1 & 91,1 & 90,1 \\
\hline Existe meio-fio/guia - em \% & 91,3 & 95,1 & 94,3 & 91,9 & 92,7 & 93,3 \\
\hline Existe bueiro/boca-de-lobo - em \% & 42,3 & 45,7 & 46,2 & 43,7 & 52,1 & 49,1 \\
\hline Existe rampa para cadeirante - em \% & 1,5 & 3,9 & 3,7 & 1,3 & 2,4 & 6,5 \\
\hline Existe arborização - em \% & 71,4 & 74,3 & 74,8 & 71,8 & 64,0 & 75,1 \\
\hline Existe esgoto a céu aberto - em \% & 4,7 & 3,1 & 3,1 & 4,0 & 5,8 & 3,6 \\
\hline Existe lixo acumulado nos logradouros - em \% & 5,2 & 4,5 & 4,4 & 4,7 & 6,0 & 4,1 \\
\hline
\end{tabular}


Como se pode ver, em termos de renda e escolaridade os empreendimentos do MCMV estão em melhores condições do que a COHAB e CDHU, com exceção da faixa 1 para o item anos médio de estudos, cujo valor é 6,9, e COHAB e CDHU é 7,1. Internamente ao MCMV, a renda e a escolaridade da faixa 1, como era de se esperar, são menores do que as faixas 2 e 3 . A estrutura etária da faixa 1 é diferente da faixa 2 e 3: no primeiro caso há menos idosos, e a proporção de pessoas com menos de 10 anos é a maior, inclusive maior que a média da RMSP. As faixas 2 e 3 possuem estrutura etária semelhantes, inclusive nos números das proporções: em relação à faixa 1 , há mais idosos, e o número de crianças é menor. Por fim, COHAB e CDHU possuem uma estrutura etária semelhante também, mas diferente das faixas 1,2 e 3.

Com relação às características dos domicílios e ao acesso a infraestrutura, as condições das faixas 2 e 3 também são melhores, quando comparados com a faixa 1, e quase indiferenciadas entre si. A presença relativa de domicílios alugados é maior no entorno dos empreendimentos do Minha Casa Minha Vida, assim como é menor a proporção de domicílios próprios em aquisição, provavelmente como produto da maior escala dos conjuntos mais antigos, aglomerados em complexos. Novamente as condições são inferiores à média da metrópole, mas chama a atenção que os entornos de condomínios da COHAB e do CDHU tendam a ter maiores proporções de lixo coletado por caçamba e menos medidores coletivos de energia, que são indicadores de baixa qualidade do serviço de infraestrutura prestado.

A maior escala dos conjuntos pode ajudar a explicar também os indicadores de entorno do setor censitário, apresentados na parte inferior da tabela. Essas variáveis dizem respeito a elementos do espaço construído observados pelo recenseador do Censo durante a coleta de dados, e não ao domicílio em si. Como se pode ver, os empreendimentos do 
programa Minha Casa Minha Vida apresentam condições muito inferiores às médias da cidade, embora as condições novamente melhorem entre as faixas da mesma forma que anteriormente. Nesse caso, entretanto, é a faixa 2 que se assemelha aos conjuntos existentes da COHAB e do CDHU, com os empreendimentos da faixa 3, apresentando melhores condições médias. Os empreendimentos da faixa 1, por outro lado, foram implantados em locais caracterizados mais frequentemente por um grau de precariedade urbana mais alta em termos da ausência de meios fios, bueiros, rampas para cadeirantes, pavimentação etc. Exceto por alguns indicadores específicos, entretanto, os patamares de infraestrutura não são muito baixos, apesar de serem inferiores aos das demais faixas e conjuntos existentes.

Com relação especificamente aos empreendimentos da faixa 1, esses dados divergem um pouco de Rolnik e Royer (2014). Sobre a produção habitacional na RMSP, as autoras destacam que os empreendimentos estão localizados na periferia da cidade de São Paulo, especificamente, na zona leste, "uma periferia consolidada, com oferta de comércio e serviços, porém com um padrão de urbanidade precário, infraestrutura urbana de baixa qualidade" (ROLNIK; ROYER, 2014, p. 18). Os dados do Censo de 2010, no que diz respeito à disponibilidade de infraestrutura urbana, demonstram que de fato para a faixa 1 a média é menor do que da faixa 2 e 3, mas a infraestrutura urbana não é tão baixa assim. Talvez haja alguns empreendimentos com valores inferiores à média, ou mesmo com valores superiores, porém em geral, os empreendimentos têm acesso à água, à energia e à coleta de lixo. No caso de água de rede, a faixa 1 tem a média $(97,6 \%)$ muito próxima da RMSP (98,7\%), e no caso de coleta de lixo por caminhão, a média é $13 \%$ maior do que da RMSP - para esgoto e medidor exclusivo de energia a média é inferior à da RMSP. Além disso, Lopes (2014), ao analisar a produção habitacional do $\mathrm{ABC}$ também conclui que os empreendimentos estão dotados de boa infraestrutura urbana e serviços e equipamentos públicos. 
Portanto, em termos de entorno, os empreendimentos da faixa 1 se assemelham aos conjuntos habitacionais existentes na metrópole, enquanto os das faixas 2 e 3 apresentam melhores condições, exceto para o entorno dos setores, onde apenas a faixa 3 apresenta melhores condições. Como a produção tradicional das companhias habitacionais estava concentrada em faixas similares à faixa 2 , é possível dizer que a semelhança com os entornos das COHAB contribui, embora de forma tênue, para a redução da segregação, diferentemente do que tem sido considerado pela maior parte dos analistas.

Por fim, para completarmos a análise da caracterização dos locais dos empreendimentos do programa e fornecer um olhar sobre a segregação sob outro ângulo, são cruzadas as informações da localização com os tipos de espaço da RMSP, construído por Marques (2014) por meio da classificação EGP que estabelece 8 tipos de classes sociais: proprietários e empregadores, profissionais, nível alto, profissionais, nível baixo, não manuais de rotina, nível alto, técnicos e supervisores, não manuais de rotina, nível baixo, manuais qualificados, manuais não qualificados. Cada espaço estabelecido pelo autor é caracterizado pela predominância de uma (ou mais de uma) dessas classes. Resumidamente (MARQUES, 2014, p. 162-164):

1 - espaços das elites: caracterizado pela elevada presença de proprietários e profissionais, com renda muito alta e escolaridade elevada;

2 - espaços das classes médias-altas: proprietários e profissionais são majoritários, mas com presença de trabalhadores não manuais de rotina nível alto, e a renda média é inferior à do espaço das elites;

3 - espaços médios-misturados: presença de profissionais, trabalhadores não manuais de rotina nível alto e técnicos e supervisores, sendo uma área misturada, com predominância de classes médias, mas grupos superiores também.

4 - espaços médios-baixos misturados: áreas com predominância de trabalhadores manuais (qualificados e não), mas também não manuais de rotina nível baixo e técnicos. Esses espaços apresentam a mais elevada presença de trabalhadores não manuais de rotina nível;

5 - espaços dos trabalhadores manuais: o último grupo apresenta uma elevada e clara predominância de trabalhadores manuais qualificados e não qualificados, com renda baixa. 
Gráfico 20 Distribuição dos empreendimentos de cada faixa por tipo de espaço - em \%

(Fonte: Dados da Caixa Econômica Federal, trabalhados sobre cartografias CEM)

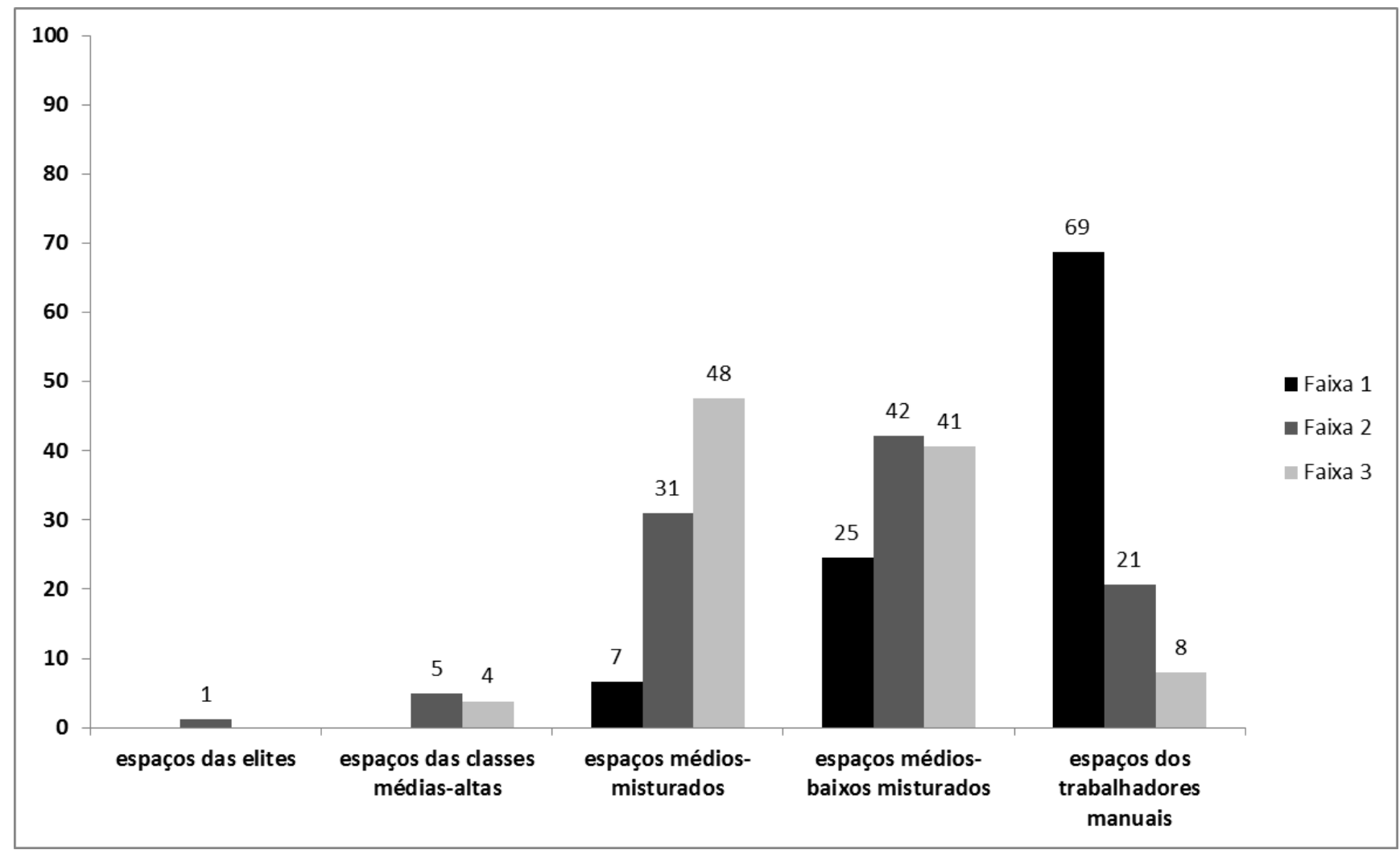

Como era de se esperar, a localização das faixas varia substancialmente por tipo de espaço, embora obedeça a um claro ordenamento. A faixa 1 está fortemente concentrada em espaços dos trabalhadores manuais - 69\%, embora com uma parcela não desprezível em espaços médio-baixos misturados $-25 \%$. As faixas 2 e 3 apresentam perfis relativamente similares. Em ambos os casos a predominância é em espaços médios-misturados e médiosbaixos misturados, embora com ênfases invertidas. A faixa 3 apresenta maior proporção de sua produção em espaços médio-misturados, enquanto a faixa 2 tem mais presença em espaços médios-baixos misturados. A faixa 2, por outro lado, também apresenta uma parcela não desprezível em espaços dos trabalhadores manuais (cerca de 21\%). Não há praticamente nenhum empreendimento em espaços das elites (apenas $1 \%$ da faixa 2), e no espaço das classes médias-altas misturadas, apenas $5 \%$ da faixa 2 e $4 \%$ da faixa 3. Essas informações 
confirmam as anteriores e reforçam a similaridade em termos de localização da faixa 1 com a produção habitacional pública tradicional paulistana (e brasileira), assim como indicam que as faixas 2 e 3 tenderam a produzir um padrão diferente e muito menos periférico em termos sócio-espaciais.

\subsection{Analisando as unidades habitacionais entregues da faixa 1}

É necessário fazer uma análise separada para os empreendimentos da faixa 1, cujas UHs já foram entregues aos mutuários finais, e, atualmente, encontram-se ocupados pelas famílias. Como o processo de entrega das chaves é mais lento, os dados disponíveis dizem respeito às entregas realizadas até novembro de 2013, quando 36 empreendimentos (29\% do total de 124 empreendimentos) já estavam concluídos, totalizando 8.368 (18\% do total de 45.932 unidades contratadas), das quais 6.714 (80\% do total de 8.368 das unidades concluídas) tinham sido entregues às famílias até a data referida. A renda média (calculada a partir da renda mensal familiar declarada quando cada mutuário se candidatou ao PMCMV) dessas pessoas é de $\mathrm{R} \$ 841,27$, ao passo que a renda média dos responsáveis dos domicílios no entorno desses empreendimentos (de acordo com os dados do Censo 2010) é R\$1099,43.

De fato, a proporção dos mutuários finais que possuem renda menor do que a dos responsáveis pelos domicílios é quase, e isso é demonstrado pelo gráfico que compara essas rendas: 
Gráfico 21 Renda dos mutuários finais da faixa 1 comparada com a renda média dos responsáveis pelos domicílios (Fonte: Dados da CEF, CENSO 2010, trabalhados sobre cartografias CEM)

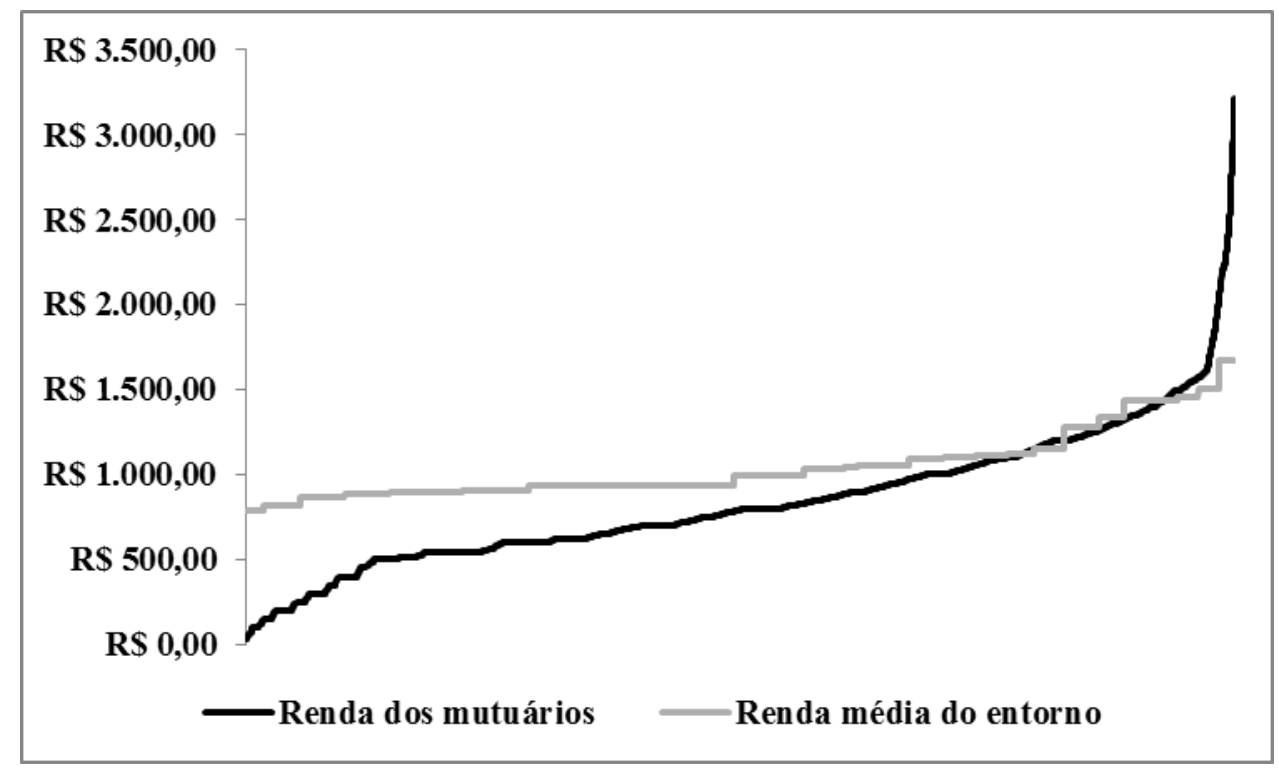

Das 6.714 famílias que receberam uma unidade pelo MCMV, apenas 466 possuíam a renda maior que a do entorno, ou seja, 6,9\%, mas esses dados correspondem a um cenário que as diferenças das rendas são consideradas precisamente, ou seja, quando uma família que declarou ganhar $\mathrm{R} \$ 1.432,80$, e a renda média desse entorno era de $\mathrm{R} \$ 1.432,31$ (diferença de 0,49 centavos). Se um critério menos restritivo é utilizado, certamente esses números alteramse: curiosamente, há famílias que ganham mais de $\mathrm{R} \$ 1.600,00$, teto limite para a faixa 1 , na fase 2 do PMCMV, e, neste caso, todas essas famílias possuem renda maior que a do entorno. São 187 (2,7\% das unidades entregues) unidades ocupadas por famílias nessa situação, e a faixa da renda delas varia de $\mathrm{R} \$ 1.606,50$ a $\mathrm{R} \$ 3.212,19$. Portanto, pode-se concluir que as moradias destinadas à faixa 1, até novembro de 2013, foram entregues a famílias que se enquadram no critério de renda do programa, com uma pouca exceção para $2,7 \%$ das UHs entregues. 
Além de analisar a renda dos mutuários tendo em vista a renda do entorno, é necessário detalhar as condições de infraestrutura urbana e qualidade do entorno desses empreendimentos entregues. Esses dados são apresentados, tendo como padrão de comparação os outros empreendimentos da faixa 1 que ainda não foram entregues. Nessa tabela, chama à atenção a diferença dos números para os domicílios com esgoto ligado a rede, e sanitário exclusivo: os entregues estão localizados em áreas com uma proporção maior de rede de esgoto e sanitário exclusivo. Além disso, a proporção da coleta de lixo por caçamba é levemente menor nas áreas das unidades entregues.

Os números dos empreendimentos entregues são melhores do que os não entregues, com exceção para a presença de bueiro, presença de rampa para cadeirante, presença de arborização. A diferença da presença de lixo acumulado é de $0,1 \%$ e pode ser desconsiderada. Esses dados sugerem que a primeira leva de UHs entregues estão localizadas em melhores áreas do que as que serão concluídas e destinadas para as famílias no futuro. Além disso, dos 36 empreendimentos entregues, apenas 6 são da fase 2, ou seja dos 58 empreendimentos contratados da fase 1 do PMCMV-faixa 1, 30 já foram entregues. É necessário que o restante dos empreendimentos da fase 1 sejam entregues para poder afirmar se a fase 1 foi melhor do que a fase 2, e até o momento só é possível concluir que com relação à qualidade do entorno e à infraestrutura urbana, as UHs entregues estão em áreas um pouco melhores que os não entregues. 
Tabela 34 Características sociais médias dos entornos (1000 metros) dos empreendimentos entregues e dos não entregues da faixa 1(Fonte: Dados da CEF, CENSO 2010, trabalhados sobre cartografias CEM)

\begin{tabular}{|c|c|c|c|c|c|}
\hline & \multicolumn{2}{|c|}{ Faixa 1} & \multirow[b]{2}{*}{ CDHU } & \multirow[b]{2}{*}{ СОНАВ } & \multirow[b]{2}{*}{ RMSP } \\
\hline & Entregues & $\begin{array}{c}\text { Não } \\
\text { entregues }\end{array}$ & & & \\
\hline \multicolumn{6}{|l|}{ Características sociais } \\
\hline Renda média & $\mathrm{R} \$ 1.125$ & $\mathrm{R} \$ 1.187$ & $\mathrm{R} \$ 1.284$ & $\mathrm{R} \$ 1.235$ & $\mathrm{R} \$ 2.029$ \\
\hline $\begin{array}{l}\text { Pessoas responsáveis com rendimento nominal } \\
\text { mensal de até } 1 / 2 \text { salário mínimo - em \% }\end{array}$ & 2,5 & 2,1 & 1,5 & 1,5 & 1,2 \\
\hline Anos médios de estudo - em anos & 7,0 & 6,9 & 7,1 & 7,1 & 8,7 \\
\hline Alfabetizados de pessoas entre 5 a 9 anos - em $\%$ & 6,9 & 6,6 & 6,3 & 6,5 & 76,1 \\
\hline Pessoas com menos de 10 anos - em \% & 18,5 & 17,8 & 17,0 & 17,4 & 14,2 \\
\hline Pessoas com mais de 65 anos - em \% & 4,5 & 4,6 & 5,1 & 5,3 & 8,5 \\
\hline População em setores subnormais - em \% & 8,3 & 12,0 & 10,8 & 11,3 & 3,3 \\
\hline \multicolumn{6}{|l|}{ Domicílios e infraestrutura } \\
\hline Domicilio próprio em aquisição - em \% & 14,7 & 12,1 & 18,8 & 19,6 & 23,0 \\
\hline Domicílio alugado - em \% & 16,1 & 17,2 & 17,5 & 17,3 & 7,6 \\
\hline Domicílio com água da rede - em \% & 98,1 & 97,8 & 98,0 & 99,1 & 98,9 \\
\hline Domicilio com esgoto e sanitário exclusivo & 87,0 & 83,9 & 87,8 & 90,8 & 92,0 \\
\hline Domicilio com serviço de lixo por caminhão - \% & 93,7 & 94,3 & 93,6 & 93,3 & 80,1 \\
\hline Domicilio com serviço de lixo por caçamba - \% & 2,8 & 2,9 & 5,0 & 6,2 & 2,7 \\
\hline Domicilio com energia rede, medidor exclusivo - $\%$ & 80,9 & 80,8 & 84,9 & 84,5 & 86,7 \\
\hline \multicolumn{6}{|l|}{ Entorno dos domicílios no setor censitário } \\
\hline Existe identificação do logradouro - em \% & 86,2 & 83,1 & 88,2 & 89,8 & 88,0 \\
\hline Existe identificação do logradouro - em \% & 96,8 & 96,3 & 96,7 & 96,6 & 96,6 \\
\hline Existe pavimentação - em \% & 92,6 & 93,2 & 95,6 & 96,7 & 95,8 \\
\hline Existe calçada - em \% & 85,8 & 85,3 & 90,1 & 91,1 & 90,1 \\
\hline Existe meio-fio/guia - em \% & 91,8 & 91,3 & 91,9 & 92,7 & 93,3 \\
\hline Existe bueiro/boca-de-lobo - em \% & 35,5 & 42,3 & 43,7 & 52,1 & 49,1 \\
\hline Existe rampa para cadeirante - em \% & 0,9 & 1,5 & 1,3 & 2,4 & 6,5 \\
\hline Existe arborização - em \% & 66,9 & 71,4 & 71,8 & 64,0 & 75,1 \\
\hline Existe esgoto a céu aberto - em \% & 5,1 & 4,7 & 4,0 & 5,8 & 3,6 \\
\hline Existe lixo acumulado nos logradouros - em \% & 6,7 & 5,2 & 4,7 & 6,0 & 4,1 \\
\hline
\end{tabular}

Por fim, cabe analisar também individualmente as distâncias dos empreendimentos entregues, os quais se localizam mais longe do que as UHs que ainda estão em construção. Essa constatação está de acordo com o que foi demonstrado anteriormente: no começo do programa, os empreendimentos da faixa 1 localizavam-se mais distante da centralidade da Sé e da Berrini, mas mais perto das centralidades mais próximas. Com a evolução do programa, essas distâncias se inverteram: os empreendimentos passaram a ficar mais próximos da Sé e 
da Berrini, e mais distantes das centralidades mais próximas. No que diz respeito aos equipamentos públicos de entretenimento e hospitais, as unidades entregues estão um pouco mais distantes do que as que serão entregues, com exceção para o Sesi e escolas. Com relação ao acesso ao transporte público, os entregues estão mais próximos do metrô e CPTM, mas isso ocorre também pois há grande quantidade de unidades entregues em Mogi da Cruzes e na zona leste de São Paulo.

Tabela 35 Média das distâncias dos empreendimentos aos itens selecionados (Fontes: dados da CEF trabalhados sob cartografia do CEM)

\begin{tabular}{|c|c|c|}
\hline & Faixa 1 entregue & Faixa 1 não entregue \\
\hline Item medido & Distância em Km & Distância em Km \\
\hline Sé & 28,0 & 25,2 \\
\hline Berrini & 30,3 & 26,7 \\
\hline Centralidade mais próxima & 8,2 & 10,6 \\
\hline Céu & 7,7 & 6,3 \\
\hline Parque & 7,3 & 6,1 \\
\hline SESC & 13,4 & 11,9 \\
\hline Sesi & 6,9 & 8,1 \\
\hline Casa, centro cultural & 9,7 & 8,3 \\
\hline Escola & 0,3 & 0,7 \\
\hline Hospital & 8,5 & 7,4 \\
\hline Estação de Metro & 3,5 & 6,2 \\
\hline Estação de CPTM & 4,0 & 5,3 \\
\hline
\end{tabular}

Partes das unidades de Mogi das Cruzes compõem o complexo de empreendimentos Jundiapeba construídos pela Cury, que totalizam 2.060 unidades $(68 \%$ de 3.000 UHs entregues em Mogi), e todas as unidades de São Paulo estão localizadas na Zona Leste. Por isso, $68 \%$ das unidades entregues estão localizadas próximas da centralidade de Mogi das Cruzes e Santo André, conforme demonstra a tabela 35. 
Tabela 36 Distribuição das unidades concluídas da faixa 1 por município (Fontes: dados da CEF trabalhados sob cartografia do CEM)

\begin{tabular}{|l|c|c|}
\hline \multicolumn{1}{|c|}{ Município } & Absoluto & \% \\
\hline Mogi das Cruzes & 3.000 & 36 \\
\hline São Paulo & 2.174 & 26 \\
\hline Guarulhos & 718 & 9 \\
\hline Taboão da Serra & 544 & 7 \\
\hline Osasco & 420 & 5 \\
\hline Suzano & 378 & 5 \\
\hline Santo Andre & 352 & 4 \\
\hline Embu & 224 & 3 \\
\hline Maua & 200 & 2 \\
\hline Diadema & 198 & 2 \\
\hline Itaquaquecetuba & 160 & 2 \\
\hline Total Geral & 8.368 & 100 \\
\hline
\end{tabular}

Tabela 37 Distribuição das unidades concluídas da faixa 1 por centralidade mais próxima (Fontes: dados da CEF trabalhados sob cartografia do CEM)

\begin{tabular}{|l|r|r|}
\hline $\begin{array}{c}\text { Centralidades } \\
\text { mais próximas }\end{array}$ & Absoluto & \% \\
\hline Mogi das Cruzes & 3.538 & 42 \\
\hline Santo André & 2.012 & 24 \\
\hline Guarulhos & 718 & 9 \\
\hline Penha & 684 & 8 \\
\hline Osasco & 642 & 8 \\
\hline Santo Amaro & 576 & 7 \\
\hline São Bernardo & 198 & 2 \\
\hline Total Geral & 8.368 & 100 \\
\hline
\end{tabular}

Esses dados sugerem que de maneira geral, as unidades entregues são melhores em alguns critérios do entorno do setor censitário e infraestrutura, e também algumas distâncias são melhores. Contudo, isso não representa uma conclusão definitiva, porque nem todas as unidades da fase 1 do programa foram entregues, e, ademais, o PMCMV ainda não se encerrou. Outro ponto que dificulta a comparação é que não existem bases cartográficas dos equipamentos públicos para toda a região metropolitana, por isso necessariamente os empreendimentos de Guarulhos estarão mais distantes do metrô, por exemplo. Uma maneira 
de contornar isso seria construir bases cartográficas do transporte público que leve em conta linhas de ônibus municipais e intermunicipais, que, considere, também, parques, casas de cultura, de todos os Municípios da Metrópole, etc. Assim, seria possível analisar com mais precisão essa questão.

\subsection{Conclusão}

Este capítulo apresentou diversos dados sobre a produção habitacional do PMCMV na RMSP. Com relação ao atendimento do déficit, a produção do Minha Casa Minha Vida não priorizou a faixa 1, a nível da Região Metropolitana, mas há Municípios que priorizaram a construção de unidades para essas famílias, assim como existem outros que simplesmente desconsideraram essa parcela da população. Por isso, é menos interessante perguntar quanto o déficit foi reduzido na Metrópole, mas sim como e onde ele foi reduzido, pois isso permite comparar os casos entre si para gerar novos dados e conhecimentos sobre o PMCMV.

Com relação à segregação, foi demonstrado que os empreendimentos da faixa 1 são mais periféricos que os das faixas 2 e 3, mas os empreendimento das faixas 2 e 3 são menos periféricos que os da COHAB e do CDHU. Vale lembrar que historicamente COHAB e CDHU pouco atingiam as famílias com renda de até 3 salários mínimos, por isso é plausível comparar a produção habitacional realizada pela COHAB e pelo CDHU com a produção do PMCMV-faixa 2, que engloba famílias com renda entre 3 e 6 salários mínimos. Portanto, desse ponto de vista, os empreendimentos da faixa 2 são menos periféricos, ao contrário do que sugeriu a literatura: de que toda a produção do PMCMV seria periférica e intensificaria a segregação urbana. 
De fato, as unidades da faixa 1 são as mais distantes dos serviços e equipamentos públicos, mas a situação não é catastrófica. A mediana das distâncias de escola é igual para as 3 faixas (300 metros), e a diferença da distância a um hospital da faixa 3 para a faixa 1 é apenas 1 quilômetro (mediana da faixa 3 é 3,7km, e da faixa 1 é 4,7km). Além disso, as medianas pouco se alteram entre as faixas no que diz respeito a parques, casa de cultura, Sesc e Sesi. Portanto, do ponto de vista do acesso a serviços e equipamentos públicos, a faixa 1 está mais segregada, porque a localização dos empreendimentos é mais periférica, mas a diferença das distâncias entre as faixas é pouca.

As faixas 2 e 3 por estarem em áreas menos periféricas podem ter acesso facilitado às cidades, o que reduziria a segregação. É importante destacar que pouco se disse na literatura crítica ao programa o fato de suas regras serem pouco claras no quesito mobilidade urbana. As Portarias dizem apenas que os empreendimentos devem estar localizados em áreas com acesso à cidade, mas não exigem, por exemplo, o comprometimento dos Municípios de apresentarem melhorias no transporte público nas regiões que recebem empreendimentos da faixa 1, principalmente, aqueles com mais de 1.500 unidades. Certamente com um transporte público mais distribuído, as unidades da faixa 1 localizadas em áreas periféricas teriam os efeitos da segregação reduzidos, pois facilitaria o acesso dessas famílias a bens, a serviços e a equipamentos públicos.

Os dados também demonstram que houve uma pouca mistura social nas três faixas, e isso ficou demonstrado pela análise dos espaços da metrópole, e pela análise da renda dos mutuários finais da faixa 1 comparada com a renda dos responsáveis pelos domicílios do entorno. Por fim, a qualidade da infraestrutura e do entorno dos empreendimentos superou o cenário crítico estabelecido pela literatura: a maioria dos empreendimentos dispõe de infraestrutura urbana e bom entorno, mas os dados das faixas 2 e 3 são um pouco superior aos da faixa 1. 


\section{Conclusão}

Tendo como pano de fundo a literatura sobre o PMCMV, desenvolvida, principalmente, por arquitetos e urbanistas, esta dissertação contribui para o debate com uma visão neoinstitucionalista da Ciência Política. Esta perspectiva adiciona no debate o argumento de que as instituições são importantes, e que é necessário analisar as regras (gerais e específicas) do programa, os atores e as instituições engajados na produção habitacional. Além disso, é essencial distinguir claramente a existência de dois Minha Casa, Minha Vida: o PMCMV-faixa 1, e o PMCMV-faixas 2 e 3. São dois programas diferentes, com regras, atores e instituições engajados na produção de moradias diferentes, e que geram resultados também distintos. Esses argumentos são de grande valor, pois concede papel ativo no processo de produção habitacional ao poder público local, e não torna a empresa de construção civil como o principal agente por aprofundar, com os empreendimentos da Faixa 1, a segregação urbana.

Além disso, ao distinguir a produção habitacional do PMCMV-faixa 1, do PMCMVfaixa 2 e 3, chega-se a uma conclusão diferente da colocada pela literatura sobre o programa: na RMSP, comparando a produção das faixas 2 e 3 com COHAB e CDHU, conclui-se que o programa não intensificou os padrões de segregação existentes, pois os empreendimentos do MCMV destinados às famílias enquadradas nas faixas 2 são menos segregados do que os da COHAB e do CDHU. Esse resultado seria improvável, caso a produção habitacional do PMCMV fosse considerada sem a distinção entre produção habitacional PMCM-faixa 1, e PMCMV-faixas 2 e 3. Com relação aos empreendimentos da faixa 1, de fato, estão localizados em regiões mais periféricas e segregadas, contudo, a provisão de infraestrutura urbana não é precária. Isso sugere que as regras do programa foram seguidas nesse quesito, e com relação ao acesso a bens e serviços públicos, os empreendimentos da faixa 1 estão 
próximos de escola, hospitais, e CEUS, porém mais distantes de equipamentos como parques, Sesc, e Sesi.

Com relação ao caráter de mercado do programa, a distinção entre o PMCMV-faixa 1 e o PMCMV-faixas 2 e 3, permite visualizar que o primeiro visa a construção de habitação de interesse social (HIS), e o segundo, de habitação de mercado popular (HMP). No primeiro tipo de produção, há um mecanismo de subsídio que pode arcar com até $80 \%$ (valores válidos para RMSP) do valor do imóvel, não há juros no financiamento, custos cartoriais, e o acesso ao FGHab concede segurança em caso de desemprego, por exemplo. Na faixa 2, o subsídio pode chegar até $13 \%$ (valores válidos para RMSP), os juros variam de 5\% a 7\% ao ano, existem descontos nos custos cartoriais e também há acesso ao FGHab.

Portanto, esses mecanismos de subsídio, as modalidades da taxa de juros praticada, a isenção e os descontos dos custos cartoriais, bem como a disponibilidade do FGHab fazem o PMCMV ser uma política social com real interesse em reduzir o déficit habitacional, ao contrário do que foi afirmado quando o programa foi lançado:

\begin{abstract}
tal como é desenhado pelo pacote, o subsídio, neste caso, tem a família semteto como "álibi social" para que o Estado favoreça, na partição da maisvalia, uma fração do capital, o circuito imobiliário (construtoras, incorporadoras e proprietários de terra). Na verdade, o subsídio está sendo dirigido ao setor imobiliário tendo como justificativa a "chancela social" dada pela habitação popular (ARANTES; FIX, 2009).
\end{abstract}

Esse tipo de afirmação não é totalmente correto, porque na faixa 1 não há um circuito imobiliário: incorporadores que compram terra por um preço $\mathrm{x}$, contratam uma construtora que realiza as obras do empreendimento e comercializam as unidades por um valor $\mathrm{x}+1$, excedente advindo da valorização do terreno. Na faixa 1, as empresas de construção civil são prestadores de serviços, e para tais, compete-lhes exclusivamente formular o projeto, apresentá-lo à Caixa e executá-lo, caso seja aprovado. A operação de compra e venda do terreno é realizada pelo FAR, cujo representante legal, a CEF, analisa o valor de venda proposto com a análise técnica realizada pela GIDUR e escolhe o menor preço. A 
comercialização das unidades cabe à $\mathrm{CEF}$, e, a seleção das famílias beneficiadas pelo programa compete à Prefeitura.

Nem toda literatura sobre o PMCMV afirma que há incorporação na faixa. Aragão e Cardoso $\left(2013\right.$, p. 37) ${ }^{10}$ reconhecem que na faixa 1 não há custos de incorporação e não há comercialização, mas essa afirmação é um pouco diferente do argumento defendido neste trabalho: para além de haver custo de incorporação na faixa 1, não há o ator incorporador, porque as empresas participam do programa como prestadoras de serviço. Mesmo Arantes e Fix (2009) reconhecem que não há custos de incorporação, mas afirmam também que o programa favorece construtoras e incorporadoras, sem esclarecer se isso ocorre em todo o programa, ou apenas na faixa 1 ou nas faixas 2 e 3.

Deve-se destacar, ainda, 3 pontos finais. Primeiramente, é preciso analisar e apontar as falhas do PMCMV pelo que é, e não pelo que poderia ser quando é comparado com o PlanHab ou com outras políticas que visam solucionar o déficit habitacional. De fato, o programa lançado em 2009 não levou em conta alguns pontos do PlanHab e da PNH, o que é diferente de afirmar a hipótese, segundo a qual o PMCMV não é orientado pela estratégia do enfrentamento do déficit, tal como estabelecido pelo PlanHab, e sim para promover o desenvolvimento econômico (BALBIM; KRAUSE, 2013). Os dados apresentados nesta dissertação demonstram que nacionalmente, o programa priorizou a construção de empreendimentos faixa 1 , mas que a redução do déficit na faixa 1 não foi tão grande quanto a das faixas 2 e 3. Além disso, se na RMSP houve Municípios, nos quais não foi construída uma unidade sequer para a faixa 1, há outros que conseguiram reduzir em mais de $80 \%$ o déficit na faixa 1. Portanto, o "MCMV seguiu as recomendações do PlanHab no quesito de disponibilizar subsídio do orçamento para as famílias com baixa renda” (DENALDI; KLINK, 
2014, p. 224, tradução nossa). Com isso, não se nega a legitimidade da crítica de que o PMCMV desconsiderou pontos do PlanHab, mas é preciso indicar quais seriam esses.

O PMCMV é uma iniciativa do Governo Federal para estimular a construção, a requalificação e a aquisição de imóveis, e a sua essência, na faixa 1, é distribuir recursos para os Estados e os Municípios, de acordo com o déficit habitacional. Isso não significa que, necessariamente, esse recurso financeiro será convertido em unidades habitacionais, porque o Município precisa assinar um termo de adesão ao programa, se comprometendo a viabilizá-lo de acordo com as regras do Minha Casa, Minha Vida. Isso também significa que caso uma empresa de construção civil queira construir um empreendimento na cidade y que não assinou o termo, essa iniciativa será impossível. Com efeito, uma das explicações para a pouca produção de unidades da faixa 1 em alguns Estados pode ser a baixa adesão dos Municípios, e é necessário questionar e investigar as razões disso. Talvez tal fato também ajude a explicar o porquê em 7 cidades da RMSP (Ferraz de Vasconcelos, Barueri, Jandira, Franco da Rocha, Vargem Grande Paulista, Santana do Parnaíba, São Caetano) foram construídos empreendimentos das faixas 2 e 3, mas nenhuma para a 1 - e todos esses Municípios possuem déficit habitacional urbano acima de 1.800 .

Com isso não se pretende afirmar que o Município possui papel central, mas tão pouco deve-se negá-lo qualquer participação no processo de produção habitacional e de implementação do programa, ou mesmo afirmar que cabe ao poder local apenas aprovar os projetos de acordo com as Leis de zoneamento e de uso do solo. O que viabiliza a construção de um empreendimento, na faixa 1, é uma tríade de três agentes: o Município, a Caixa, e a empresa. Deve haver uma coordenação entre esses atores e em cada um deles ocorrem processos de tomadas de decisão: caso a empresa encontre um terreno que possa receber um empreendimento, mas que não possui infraestrutura urbana, é possível negociar com a Prefeitura, ou mesmo com o FAR, por exemplo. Além disso, caso o processo de aprovação do 
projeto na Prefeitura seja muito moroso, isso representará custos para a empresa, que certamente fará pressão ou tentará descobrir o motivo do atraso. Esses são alguns exemplos que demonstram a participação dos três atores no processo de produção das casas. De fato,

\begin{abstract}
os projetos da faixa 1 requerem um papel ativo dos governos locais, tanto registrando e organizando as famílias beneficiárias, como através da provisão de terra e infraestrutura urbana adicional, para que se possa gerar projetos viáveis financeiramente dentro do preço limite da venda e dos subsídios (DENALDI; KLINK, 2014, p. 224, tradução nossa).
\end{abstract}

Além de participar do processo de aprovação dos empreendimentos faixa 1, selecionar e organizar as famílias beneficiárias, e poder contribuir com infraestrutura urbana, é competência exclusiva das prefeituras realizar o trabalho técnico e social junto às famílias. $\mathrm{O}$ PMCMV reserva $2 \%$ do valor de cada unidade, ou seja, um empreendimento com 100 unidades, comercializadas a 96 mil disporá de 192 mil para que a prefeitura realize o trabalho técnico social. Curiosamente, pouca pesquisa tem sido feita sobre essa etapa do programa que é tão importante quanto às outras, pois é um trabalho de acompanhamento das famílias que até então viviam em áreas de risco, sem pagar aluguel, luz, água, e que não conviviam coletivamente, e que passaram a morar em outras condições habitacionais.

Por fim, Rolnik e Royer (2014) apontam padrões diferentes no porte dos empreendimentos, ao comparar a Região Metropolitana de Campinas (RMC) com a RMSP. É profícuo o caminho de estudar cada Metrópole na sua especificidade, somada a distinção entre PMCMV-faixa 1 e PMCMV-faixas 2 e 3, bem como a consideração dos atores, regras e instituições envolvidas na produção habitacional. Isto porque, se torna possível analisar as especificidades de cada caso, evitando afirmações generalizantes como o PMCMV acentua a segregação nos Municípios, ou ainda que não atende o déficit da faixa 1. É possível haver cidades com empreendimentos segregados e com péssima infraestrutura urbana, o que representaria um desrespeito das regras do programa e uma oportunidade para se analisar como a Prefeitura, em conjunto com a empresa e a Caixa, produziu tal empreendimento. 
Contudo, a visualização desse cenário hipotético só é possível se as regras, os atores e as instituições forem levados em conta para a análise da produção habitacional do programa. 


\section{Bibliografia}

\section{Literatura teórica}

ARAÚJO, F. S.; CARDOSO, A. L.; JAENISCH, S. T. Morando no limite: sobre padrões de localização e acessibilidade do Programa Minha Casa Minha Vida na Região Metropolitana do Rio de Janeiro. IN: XV Encontro da Associação Nacional de Pós-Graduação e Pesquisa em planejamento urbano e regional. Pernambuco: Recife, 2013, p. 1-16.

ARANTES, Pedro; FIX, Mariana. Como o governo Lula pretende resolver o problema da habitação (Parte 1, 2 e 3). Website. Disponível em: http://passapalavra.info/?p=9445, http://passapalavra.info/?p=10258, http://passapalavra.info/?p=10735. Acesso em 09 mai. 2009.

ARRETCHE, Marta. Intervenção do Estado e setor privado: o modelo brasileiro de política habitacional. Espaço \& Debate, nº. 31, p. 21-36, 1990.

Marta. Uma Contribuição para fazermos avaliações menos ingênuas. In: Carvalho, Maria do C. B. de; Moreira, Maria C. R. (Org.). Tendências e Perspectivas na Avaliação de Políticas e Programas Sociais. São Paulo: IEE/PUCSP, 2001, v. 1, p. 7-224.

Marta. Federalismo e relações intergovernamentais no Brasil: a reforma de programas sociais. Dados, vol. 45, nº. 3, p. 431-458, 2002.

ANDRADE, Luis A. G. de; AZEVEDO, Sérgio de. Habitação e poder: da fundação da casa popular ao banco nacional da habitação. Rio de Janeiro: Zahar, 1982. 135p.

BALBIM, R. N.; KRAUSE, C. H.; NETO, V. C. L. Minha Casa Minha Vida, nosso crescimento: como fica a política habitacional. IN: XV Encontro da Associação Nacional de Pós-Graduação e Pesquisa em planejamento urbano e regional. Pernambuco: Recife, 2013, p. $1-17$.

BONDUKI, Nabil. Origens da habitação social no Brasil: arquitetura moderna, Lei do inquilinato e difusão da casa própria. $3^{\text {a }}$ Edição. São Paulo: Estação Liberdade: FAPESP, 2002. 343p.

Do Projeto Moradia ao Programa Minha Casa Minha Vida. Teoria e Debate, v. 82, maio/junho, p. 8-14, 2009.

Pioneiros da habitação social: volume 1. Editora Unesp, 2014, 390p.

BOUlOS, G.; RIBEIRO, A.; SZERMETA, N. Como não fazer política urbana. Carta Capital, 30 Jan. 2014. Disponível em: http://www.cartacapital.com.br/politica/como-naofazer-politica-urbana-3066.html. Acessado em: 22 abr. 2015.

CARDOSO, A.; NUNES JUNIOR, D.; ARAÚJO, F.; SILVA, A; ARAGÃO, T. e AMORIM, T. 2013. Minha Casa Minha Sina: implicações da recente produção habitacional pelo setor privado na Zona Oeste da cidade do Rio de Janeiro. In: Cardoso, A. (org.). O programa Minha Casa Minha Vida e seus efeitos territoriais. Rio de Janeiro: IPPUR/Letra Capital. 
CARVALHO, José M. de Carvalho. Cidadania no Brasil: o longo caminho. $10^{\circ}$ Edição. Rio de Janeiro: Civilização Brasileira, 2005. 236p.

DIAS, E. Do Plano Real ao Programa Minha Casa, Minha vida: negócios, votos e as reformas da habitação. São Paulo: USP, 2012, 168p.

D’AMICO, F. O Programa Minha Casa, Minha Vida e a Caixa Econômica Federal. Caixa Econômica Federal. IN: COSTA, C. J. et al. O desenvolvimento econômico brasileiro e a Caixa: trabalhos premiados. Rio de Janeiro: Centro Internacional Celso Furtado de Políticas para o Desenvolvimento/Universidade Caixa, 2011, p. 33-54.

DENALDI, R.; KLUNK, J. On financialization and state spatial fixes in Brazil. A geographical and historical interpretation of the housing program My House My Life. Habitat International, nº44, p. 220-226, 2014.

FUNDAÇÃO JOÃO PINHEIRO. Déficit Habitacional no Brasil 2009. Belo Horizonte, 2012, 200p.

FUNDAÇÃO JOÃO PINHEIRO. Déficit Habitacional municipal no Brasil. Belo Horizonte, 2013, 78p.

FUNDAÇÃO JOÃO PINHEIRO. Déficit habitacional no brasil 2011-2012: resultados preliminares. Belo Horizonte, 2014, 20p.

HILL, Michael. The public policy process. 4th Edition. Pearson Longman, 2005. 308p.

HALL, P.; TAYLOR, R. As três versões do neo-institucionalismo. Lua Nova, São Paulo, ${ }^{\circ}$ 58, p. 193-223, 2003.

IMMERGUT, E. As regras do jogo: A lógica da política de saúde na França, na Suíça e na Suécia. Revista Brasileira de Ciências Sociais, vol. 11, nº 30, p. 1-22, 1996.

IMMERGUT, E. The theoritical core of the new institutionalism. Politics Society, vol. 26, $\mathrm{n}^{\circ}$ 1, p. 5-34, 1998.

INSTITUTO DE PESQUISA ECONÔMICA APLICADA. Estimativas do défitic habitacional brasileiro (PNAD 2007 e 2012). Brasília, DF, 2013.

LOPES, F. T. A. A Produção do Programa Minha Casa, Minha Vida na Região do ABC Paulista. São Paulo: UFABC, 2014, 114p.

MARICATO, Ermínia. Política habitacional no regime militar: do milagre brasileiro à crise econômica. Petrópolis: Vozes, 1987. 96p.

. Política urbana e de habitação social: um assunto pouco importante para o governo FHC. Revista Praga, São Paulo: Hucitec, v. 1, nº 6, p. 67-78, 1998.

MARQUES, Eduardo C. L. Urbanização e integração de assentamentos precários. Projeto Perspectivas dos investimentos sociais no Brasil (PIS), mimeo, p. 1-34, 2010. 
MARQUES, Eduardo; TORRES, Haroldo. São Paulo: segregação, pobreza e desigualdade. Editora Senac: São Paulo, 2005, 329p.

MARQUES, Eduardo (org). São Paulo, 2010: Espaços, heterogeneidade e desigualdades na metrópole, mimeo, 2014, 358P.

NASCIMENTO, Denise Morado; TOSTES, Simone Parrela. Programa Minha Casa Minha Vida: a (mesma) política habitacional no Brasil. Arquitextos, São Paulo, 2011. Acesso em: 02 set. 2011. WebSite. http://www.vitruvius.com.br/revistas/read/arquitextos/12.133/3936.

PEQUENO, L. R. B. Minha Casa Minha Vida em Fortaleza: novas periferias? IN: XV Encontro da Associação Nacional de Pós-Graduação e Pesquisa em planejamento urbano e regional. Pernambuco: Recife, 2013, p. 1-18.

RIBEIRO, L. C. Q. Dos cortiços aos condomínios fechados: as formas de produção da moradia na cidade do Rio de Janeiro. $1^{a}$ Edição. Rio de Janeiro: Civilização Brasileira, 1997, $352 \mathrm{p}$.

ROLNIK, R. La Democracia en el filo de la navaja: límites y posibilidades para la implementación de una agenda de reforma urbana en Brasil. Revista Eure, v. xxxv, nº 104, p. $5-27,2009$

ROLNIK, R.; NAKANO, A. K. As armadilhas do pacote habitacional. Le monde diplomatique, São Paulo, n. ${ }^{\circ} 2$ p. 4 - 5, 2009.

ROLNIK, R.; ROYER, L. O programa Minha Casa Minha Vida nas Regiões Metropolitanas de São Paulo e Campinas: aspectos socioespaciais e segregação. In: III Encontro da Associação Nacional de Pesquisa e Pós-graduação em Arquitetura e Urbanismo arquitetura, cidade e projeto: uma construção coletiva. São Paulo, 2014, p. 1-23.

SANTOS, Wanderley G. dos Santos. Cidadania e Justiça. Rio de Janeiro: Campus, 1979. $138 \mathrm{p}$.

SHIMBO, Lúcia Z. Habitação Social, Habitação de Mercado: a confluência entre Estado, empresas construtoras e capital financeiro. São Carlos: EESC-USP, 2010. 359p. Tese de doutorado.

SKOCPOL, T. Bringing the State Back In: Strategies of Analysis in Current Research. IN: EVANS, P; RUESCHEMEYER, D.; SKOCPOL, T. Bringing the State Back In. Cambridge university press, p. 3-37, 1985.

\section{Legislação consultada}

BRASIL. Lei $\mathrm{n}^{\circ}$ 4.380, de 21 de agosto de 1964. Cria o Banco Nacional da Habitação (BNH), e Sociedades de Crédito Imobiliário, as Letras Imobiliárias, o Serviço Federal de Habitação e Urbanismo e dá outras providências. Diário Oficial da União, Brasília, DF, 30 set. 1964a. 
BRASIL. Lei $\mathrm{n}^{\circ}$ 4.591, de 16 de dezembro de 1964. Dispõe sôbre o condomínio em edificações e as incorporações imobiliárias. Diário Oficial da União, Brasília, DF, 21 dez. 1964b.

BRASIL. Lei $\mathrm{n}^{\circ}$ 5.762, de 14 de dezembro de 1971. Transforma o Banco Nacional da Habitação (BNH) em emprêsa pública, e dá outras providências. Diário Oficial da União, Brasília, DF, 16 dez. 1971.

BRASIL. Lei no 10.188, de 12 de fevereiro de 2001. Cria o Programa de Arrendamento Residencial, institui o arrendamento residencial com opção de compra e dá outras providências. Diário Oficial da União, Brasília, DF, 14 fev. 2001.

BRASIL. Lei $\mathrm{n}^{\circ} 11.474$, de 15 de maio de 2007. Altera a Lei no 10.188, de 12 de fevereiro de 2001, que cria o Programa de Arrendamento Residencial, institui o arrendamento residencial com opção de compra. Diário Oficial da União, Brasília, DF, 16 mai. 2007.

BRASIL. Portaria no 139 de 13 abril de 2009. Dispõe sobre a aquisição e alienação de imóveis sem prévio arrendamento no âmbito do Programa de Arrendamento Residencial PAR. Diário Oficial da União, Brasília, DF, 13 abr. 2009a.

BRASIL. Instrução Normativa RFB n 934, de 27 de abril de 2009.Dispõe sobre o regime especial de tributação aplicável às incorporações imobiliárias e sobre o pagamento unificado de tributos aplicável às construções de unidades habitacionais contratadas no âmbito do Programa Minha Casa, Minha Vida. Diário Oficial da União, Brasília, DF, 29 abr. 2009b.

BRASIL. Lei n ${ }^{\circ} 11.977$, de 7 de julho de 2009. Dispõe sobre o Programa Minha Casa Minha Vida - PMCMV e a regularização fundiária de assentamentos localizados em áreas urbanas. Diário Oficial da União, Brasília, DF, 8 jul. 2009c. Seção 1, p. 2.

BRASIL. Lei $\mathrm{n}^{\mathrm{o}}$ 12.024, de 27 de agosto de 2009. Dispõe sobre o tratamento tributário a ser dado às receitas mensais auferidas pelas empresas construtoras nos contratos de construção de moradias firmados dentro do Programa Minha Casa, Minha Vida - PMCMV. Diário Oficial da União, Brasília, DF, 28 ago. 2009d.

BRASIL. Ministério das Cidades. Secretaria Nacional de Habitação. Avanços e Desafios: Política Nacional de Habitação. Brasília, DF, 2010a.

BRASIL. Ministério das Cidades. Secretaria Nacional de Habitação. Como produzir moradia bem localizada com recursos do programa minha casa minha vida? Brasília, DF, 2010b.

BRASIL. Lei $n^{\circ} 12.249$, de 11 de junho de 2010. Ajusta o Programa Minha Casa Minha Vida - PMCMV. Diário Oficial da União, Brasília, DF, 14, jun. 2010c. Seção 1, p. 1.

BRASIL. Lei no 12.424, de 16 de junho 2011. Altera a Lei no 11.977, de 7 de julho de 2009, que dispõe sobre o Programa Minha Casa, Minha Vida - PMCMV e a regularização fundiária de assentamentos localizados em áreas urbanas. Diário Oficial da União, Brasília, DF, 16 jun. 2011a. Seção 1, p. 2. 
BRASIL. Decreto $\mathrm{n}^{\mathrm{o}}$ 7.499, de 16 de junho de 2011. Regulamenta dispositivos da Lei no 11.977, de 7 de julho de 2009, que dispõe sobre o Programa Minha Casa, Minha Vida, e dá outras providências. Diário Oficial da União, Brasília, DF, 17 jun. 2011 b.

BRASIL. MINISTÉRIO DAS CIDADES. SECRETARIA NACIONAL DE HABITAÇÃO. Déficit habitacional no Brasil 2008. Brasília, DF, 2011c, 140p.

BRASIL. Portaria no 465, de 03 de outubro de 2011. Dispõe sobre as diretrizes gerais para aquisição e alienação de imóveis por meio da transferência de recursos ao Fundo de Arrendamento Residencial - FAR. Diário Oficial da União, Brasília, DF, 4 out. 2011d.

BRASIL. Portaria $n^{\circ} 521$, de 22 de outubro de 2012. Dá nova redação à Portaria $n^{\circ} 465$, de 3 de outubro de 2011, do Ministério das Cidades, que dispõe sobre as diretrizes gerais para aquisição e alienação de imóveis por meio do Fundo de Arrendamento Residencial - FAR, no âmbito do Programa Nacional de Habitação Urbana - PNHU, integrante do Programa Minha Casa, Minha Vida - PMCMV. Diário Oficial da União, Brasília, DF, 04 jan. 2012a.

BRASIL. Lei $\mathrm{n}^{\mathrm{o}}$ 12.693, de 24 de julho de 2012. Altera a 11.977, de 7 de julho de 2009, 10.188, de 12 de fevereiro de 2001 e dá outras providências. Diário Oficial da União, Brasília, DF, 25 jul. 2012 b.

BRASIL. Decreto $\mathrm{n}^{\circ} 7.795$ de 24 de agosto de 2012. Altera o Decreto $\mathrm{n}^{\mathrm{o}} 7.499$, de 16 de junho de 2011, que regulamenta dispositivos da Lei $\mathrm{n}^{\circ} 11.977$, de 7 de julho de 2009, que dispõe sobre o Programa Minha Casa, Minha Vida - PMCMV. Diário Oficial da União, Brasília, DF, 27 ago. 2012c.

BRASIL. Lei n ${ }^{\circ} 12.722$, de 3 de outubro de 2012. Altera a 11.977, de 7 de julho de 2009, e dá outras providências. Diário Oficial da União, Brasília, DF, 04 out. 2012d.

BRASIL. Decreto $\mathrm{n}^{\mathrm{o}} 7.825$, de 11 de outubro de 2012. Altera o Decreto $\mathrm{n}^{\mathrm{o}} 7.499$, de 16 de junho de 2011, que regulamenta dispositivos da Lei $\mathrm{n}^{\mathrm{o}}$ 11.977, de 7 de julho de 2009, que dispõe sobre o Programa Minha Casa, Minha Vida. Diário Oficial da União, Brasília, DF, 15 out. 2012e.

BRASIL. Instrução normativa $n^{\circ} 35$, de 23 de outubro de 2012. Regulamenta o Programa Carta de Crédito Associativo. Diário Oficial da União, Brasília, DF, 24 out. 2012f.Seção 1, págs. 96/99.

BRASIL. Instrução normativa $\mathrm{n}^{\circ}$ 33, de 23 de outubro de 2012. Regulamenta o Programa de Apoio à produção de habitações. Diário Oficial da União, Brasília, DF, 24 out. 2012g. Seção 1, págs. 92/94.

BRASIL. Portaria $\mathrm{n}^{\circ}$ 24, de 18 de janeiro de 2013. Dispõe sobre a divulgação, publicidade e identidade visual do Programa Minha Casa, Minha Vida - PMCMV, e dá outras providências. Diário Oficial da União, Brasília, DF, 21 jan. 2013a. Seção 1, págs. 70/71.

BRASIL. Portaria $\mathrm{n}^{\mathrm{o}}$ 107, de 26 de fevereiro de 2013. Estabelece as diretrizes gerais e o calendário para habilitação de entidades privadas sem fins lucrativos, como Entidade Organizadora - EO, no âmbito dos programas de habitação de interesse social geridos pelo 
Ministério das Cidades, e dá outras providências. Diário Oficial da União, Brasília, DF, 27 fev. 2013b.

BRASIL. Portaria $n^{\circ} 168$, de 12 de abril de 2013. Dispõe sobre as diretrizes gerais para aquisição e alienação de imóveis com recursos advindos da integralização de cotas no Fundo de Arrendamento Residencial - FAR, no âmbito do Programa Nacional de Habitação Urbana - PNHU, integrante do Programa Minha Casa, Minha Vida - PMCMV. Diário Oficial da União, Brasília, DF, 15 abr. 2013c.

BRASIL. Instrução normativa $\mathrm{n}^{\circ}$ 14, de 10 de julho de 2013. Regulamenta o Programa Minha Casa, Minha Vida - Entidades - PMCMV-E. Diário Oficial da União, Brasília, DF, 12 jul. $2013 d$.

BRASIL. Portaria no 355, de 6 de agosto de 2013. Dispõe sobre a alienação de imóveis adquiridos com recursos Fundo de Arrendamento Residencial - FAR, no âmbito do Programa Nacional de Habitação Urbana - PNHU, integrante do Programa Minha Casa, Minha Vida PMCMV, nas condições em que especifica. Diário Oficial da União, Brasília, DF, 7 ago. 2013e. Seção 1, pg. 40.

BRASIL. Portaria $n^{\circ} 518$, de 8 de novembro de 2013. Dá nova redação à Portaria $n^{\circ} 168$, de 12 de abril de 2013, do Ministério das Cidades, que dispõe sobre as diretrizes gerais para aquisição, requalificação e alienação de imóveis com recursos advindos da integralização de conta no Fundo de Arrendamento Residencial (FAR), no âmbito do Programa Nacional de Habitação Urbana (PNHU), integrante do Programa Minha Casa, Minha Vida (PMCMV). Diário Oficial da União, Brasília, DF, 11 nov. 2013f. Seção 1, pág. 62.

BRASIL. FAR - PMCMV - MANUAL DE NORMAS E PROCEDIMENTOS OPERACIONAIS - MNPO. Brasil, Caixa, 2014a. Disponível em: http://www1.caixa.gov.br/download/asp/download.asp. Acessado em: 12 out. 2014.

BRASIL. Instrução Normativa RFB n 1.435 , de 30 de dezembro de 2013. Dispõe sobre os regimes especiais de pagamento unificado de tributos aplicáveis às incorporações imobiliárias, às construções de unidades habitacionais contratadas no âmbito do Programa Minha Casa, Minha Vida (PMCMV) e às construções ou reformas de estabelecimentos de educação infantil. Diário Oficial da União, Brasília, DF, 2 jan. 2014 b.

BRASIL. Portaria n 176, de 10 de abril de 2014. Dá nova redação à Portaria no 168/2013, do Ministério das Cidades, que dispõe sobre as diretrizes gerais para aquisição, requalificação e alienação de imóveis com recursos advindos da integralização de cota do FAR, no âmbito do PNHU, integrante do PMCMV. Diário Oficial da União, Brasília, DF, 11 abr. 2014. Seção 1, pág. 79. 